ESRI

RESEARCH

SERIES

NUMBER 88

May 2019

\section{ATTRACTING AND RETAINING INTERNATIONAL HIGHER EDUCATION STUDENTS: IRELAND}

SARAH GROARKE AND CHRISTINA DURST

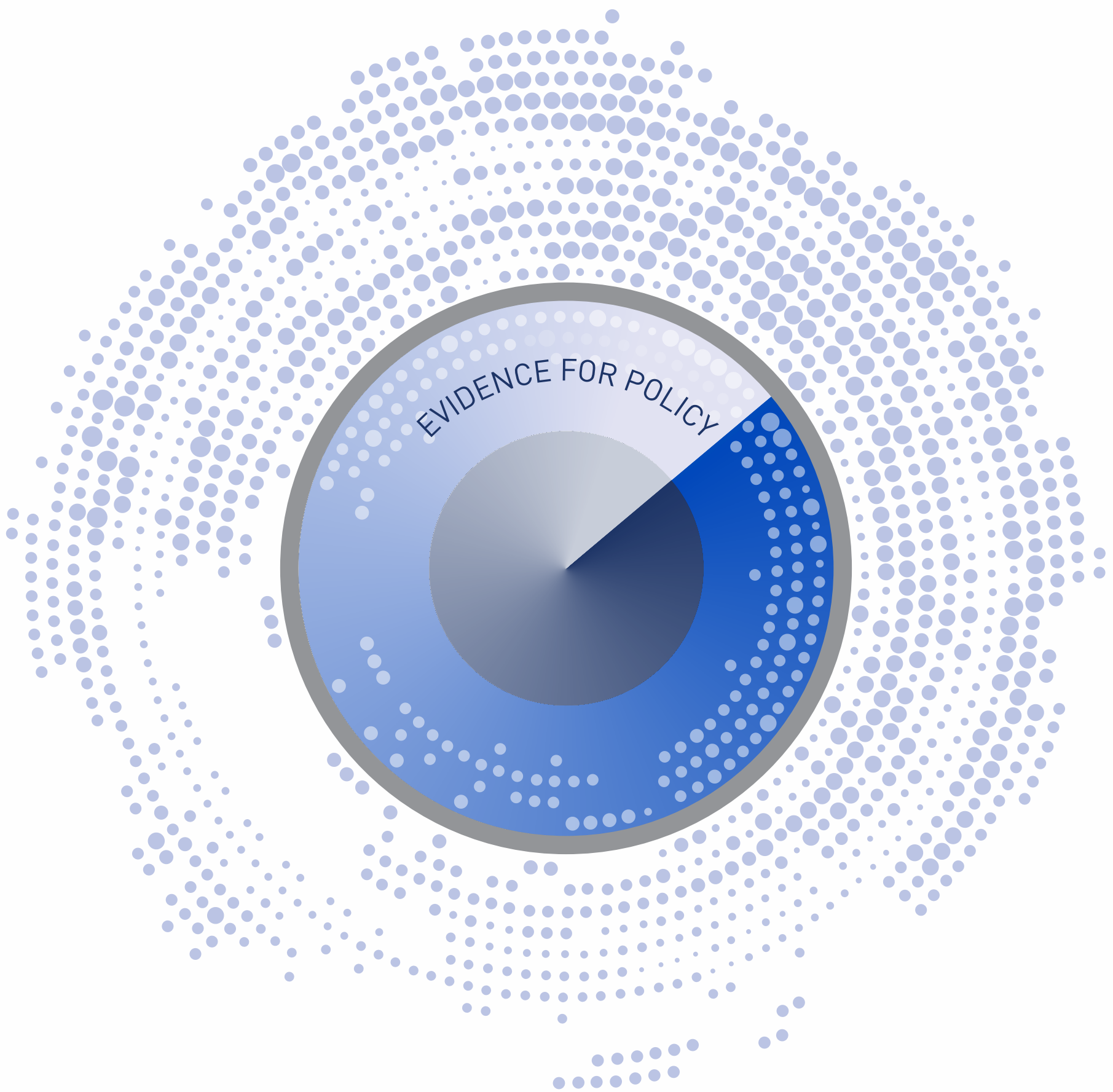




\title{
ATTRACTING AND RETAINING INTERNATIONAL HIGHER EDUCATION STUDENTS: IRELAND
}

\author{
Sarah Groarke
}

Christina Durst

May 2019

\section{RESEARCH SERIES}

\section{NUMBER 88}

Study completed by the Irish National Contact Point of the European Migration Network (EMN), which is financially supported by the European Union and the Irish Department of Justice and Equality. The EMN was established via Council Decision 2008/381/EC.

Available to download from www.emn.ie

(C) The Economic and Social Research Institute Whitaker Square, Sir John Rogerson's Quay, Dublin 2

ISBN: 978-0-7070-0493-8

DOI: https://doi.org/10.26504/rs88

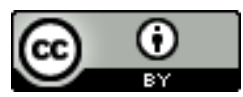

This Open Access work is licensed under a Creative Commons Attribution 4.0 International License, which permits unrestricted use, distribution, and reproduction in any medium, provided the original work is properly credited. 


\section{THE EUROPEAN MIGRATION NETWORK}

The aim of the European Migration Network (EMN) is to provide up-to-date, objective, reliable and comparable information on migration and asylum at Member State and EU levels with a view to supporting policymaking and informing the general public.

The Irish National Contact Point of the European Migration Network, EMN Ireland, sits within the Economic and Social Research Institute (ESRI).

\section{ABOUT THE ESRI}

The mission of the Economic and Social Research Institute is to advance evidencebased policymaking that supports economic sustainability and social progress in Ireland. ESRI researchers apply the highest standards of academic excellence to challenges facing policymakers, focusing on 12 areas of critical importance to 21st Century Ireland.

The Institute was founded in 1960 by a group of senior civil servants led by Dr T.K. Whitaker, who identified the need for independent and in-depth research analysis to provide a robust evidence base for policymaking in Ireland.

Since then, the Institute has remained committed to independent research and its work is free of any expressed ideology or political position. The Institute publishes all research reaching the appropriate academic standard, irrespective of its findings or who funds the research.

The quality of its research output is guaranteed by a rigorous peer review process. ESRI researchers are experts in their fields and are committed to producing work that meets the highest academic standards and practices.

The work of the Institute is disseminated widely in books, journal articles and reports. ESRI publications are available to download, free of charge, from its website. Additionally, ESRI staff communicate research findings at regular conferences and seminars.

The ESRI is a company limited by guarantee, answerable to its members and governed by a Council, comprising 14 members who represent a cross-section of ESRI members from academia, civil services, state agencies, businesses and civil society. The Institute receives an annual grant-in-aid from the Department of Public Expenditure and Reform to support the scientific and public interest elements of the Institute's activities; the grant accounted for an average of 30 per cent of the Institute's income over the lifetime of the last Research Strategy. The remaining funding comes from research programmes supported by government departments and agencies, public bodies and competitive research programmes. Further information is available at www.esri.ie. 


\section{THE AUTHORS}

Sarah Groarke is a Policy Officer at the Irish National Contact Point of the European Migration Network (EMN Ireland), within the ESRI. Christina Durst was an Intern at EMN Ireland.

\section{ACKNOWLEDGEMENTS}

In compiling this study, valuable assistance was received from officials within the Higher Education Authority (HEA), Enterprise Ireland, the Irish Council for International Students (ICOS) and Crosscare. Information was also obtained through correspondence with the Irish Naturalisation and Immigration Service (INIS), the Department of Education and Skills, the Department of Business, Enterprise and Innovation, the Irish Universities Association (IUA), the Technological Higher Education Association (THEA) and the Higher Education Colleges Association (HECA). We would like to thank those international offices of higher education institutions that provided input through an online survey. We also acknowledge the useful comments and suggestions received from the referees. Thanks are due to Emma Quinn, Head of EMN Ireland, for comments and guidance. Finally, thanks are due to our colleagues Anne Sheridan, Frank McNamara, Elaine Byrne and Sarah Burns at the ESRI. We are grateful to everyone who shared their expertise with us for the purpose of writing this study.

\section{ABOUT THIS REPORT}

This European Migration Network study examines policy, law and practice relating to non-EEA students in higher education in Ireland. In particular, it looks at measures to attract international students to Ireland and to retain them following graduation. The report consists of information gathered by way of a common template, primarily for a forthcoming EU-level synthesis report: Attracting and retaining international students in the $E U$, which will be published at: www.emn.ie and www.ec.europa.eu/emn.

This report has been accepted for publication by the Institute, which does not itself take institutional policy positions. All ESRI Research Series reports are peer reviewed prior to publication. The authors are solely responsible for the content and the views expressed do not represent the position of the Economic and Social Research Institute, the Irish Naturalisation and Immigration Service, the Department of Justice and Equality, or the European Commission, Directorate-General Migration and Home Affairs. 
Abbreviations and Irish terms

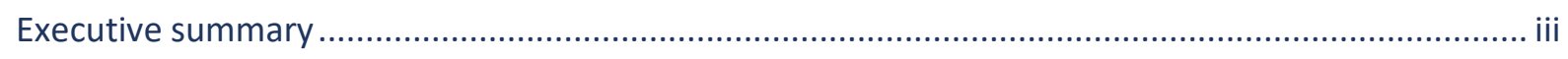

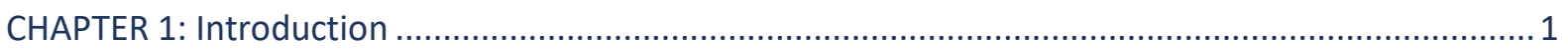

1.1 Objectives and background to the study........................................................... 1

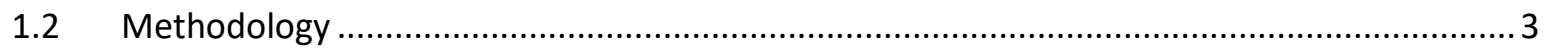

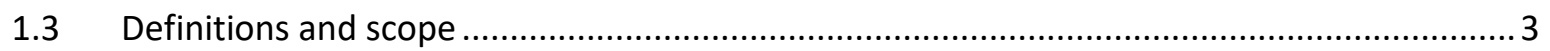

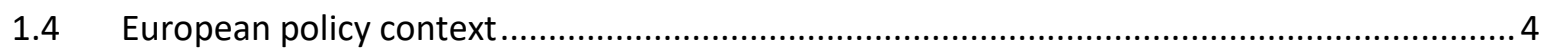

1.4.1 Overview of main trends regarding non-EEA students in EU Member States .......... 7

1.5 Irish policy background ................................................................................. 13

1.5.1 Overview of trends in relation to non-EEA students in Ireland............................. 15

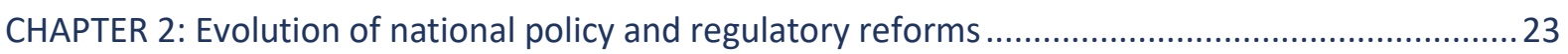

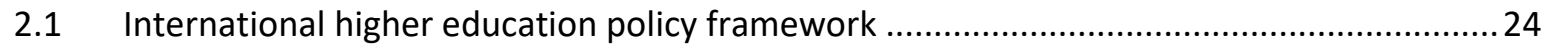

2.1.1 International education strategies ......................................................... 24

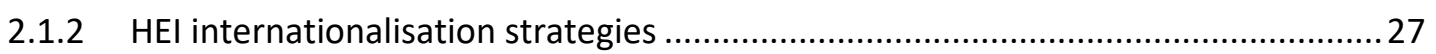

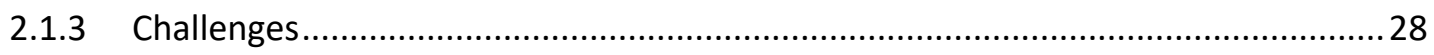

2.2 Non-EEA student education and immigration regulatory reform .....................................30

2.2.1 Quality assurance: The International Education Mark (IEM) .............................31

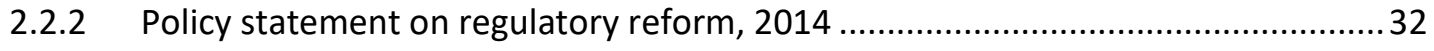

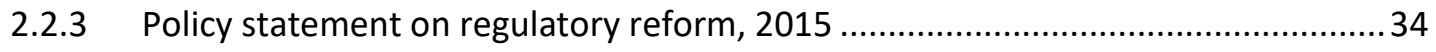

2.2.4 Further reforms and policy developments ............................................ 36

CHAPTER 3: Attracting international students.............................................................. 40

3.1 Promoting Ireland as a destination for non-EEA students .......................................... 40

3.1.1 Marketing and promotion of international higher education............................. 42

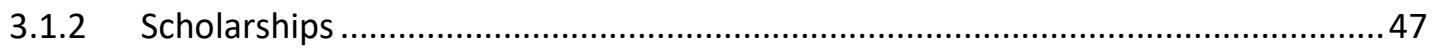

3.1.3 Alumni engagement......................................................................... 50

3.2 Facilitating international student admission and stay ............................................. 51

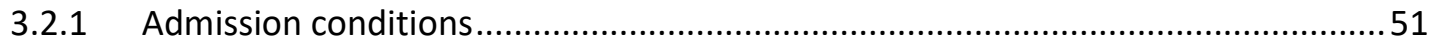

3.2.2 Access to orientation supports .............................................................. 62

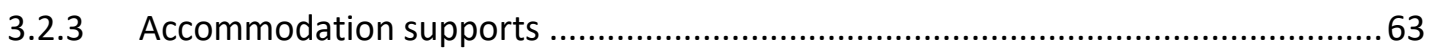

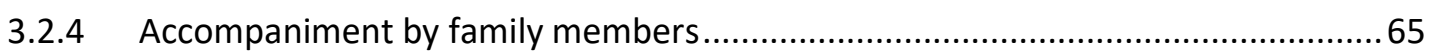

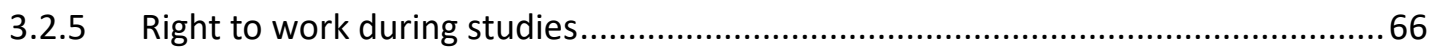


CHAPTER 4: Retaining students: Facilitating stay and access to employment after studies .68

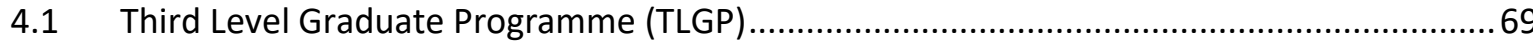

4.2 General employment permit and critical skills employment permit ...............................70

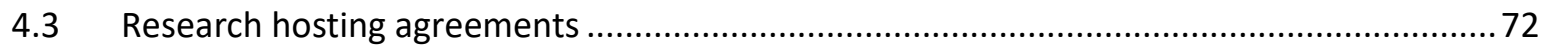

4.4 Start-up Entrepreneur Programme ...................................................................... 73

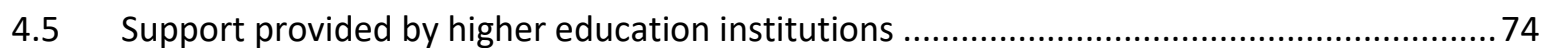

CHAPTER 5: Cooperation with non-EEA countries on higher education ........................................ 75

5.1 Bilateral agreements between Ireland and third countries ....................................... 75

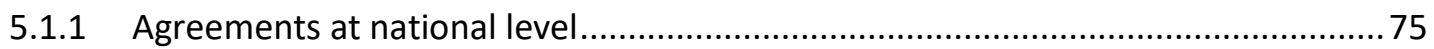

5.1.2 Agreements at institutional level .......................................................... 76

5.1.3 Other agreements........................................................................... 78

5.2 Provision of transnational higher education ............................................................ 79

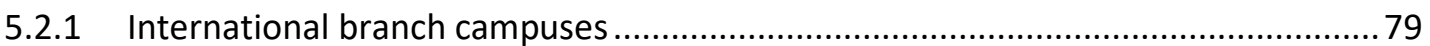

5.2.2 Delivery of programmes overseas ............................................................. 80

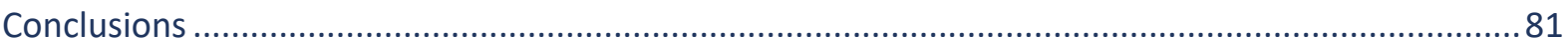

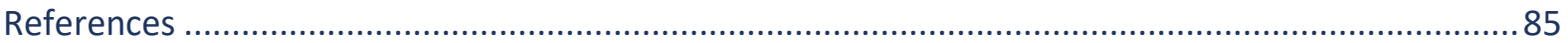


Figure 1.1 First residence permits issued in EU Member States, 2013-2017 ........................... 8

Figure 1.2 Percentage of first-residence permits issued for study and other educational reasons out of total first permits in EU Member States, 2017.................................................. 9

Figure 1.3 First-residence permits issued for study in EU Member States, 2017.......................11

Figure 1.4 Proportion of non-EEA and EU students among total students in higher education in

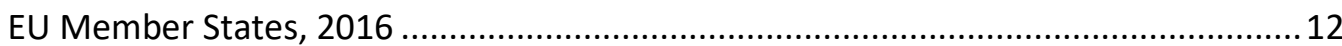

Figure 1.5 First-residence permits issued in Ireland, 2013-2017 .............................................. 17

Figure 1.6 First residence permits issued for education-related reasons in Ireland, 2013-2017.18

Figure 1.7 Students enrolled in full-time higher education programmes in public HEls by domiciliary of origin, 2013-2017

Figure 1.8 Non-EEA student enrolments in full-time higher education courses in public HEls per field, 2017-2018 academic year .

Figure 1.9 Number of non-EEA graduates of public HEls in Ireland, 2013-2017 22

\section{LIST OF TABLES}

Table 4.1 


\section{ABBREVIATIONS AND IRISH TERMS}

\begin{tabular}{|c|c|}
\hline AIT & Athlone Institute of Technology \\
\hline EEA & European Economic Area \\
\hline EHEA & European Higher Education Area \\
\hline EMN & European Migration Network \\
\hline EU & European Union \\
\hline GDP & Gross domestic product \\
\hline GNIB & Garda National Immigration Bureau \\
\hline HEA & Higher Education Authority \\
\hline HECA & Higher Education Colleges Association \\
\hline HEI & Higher education institution \\
\hline IUA & Irish Universities Association \\
\hline ICOS & Irish Council for International Students \\
\hline IEM & International Education Mark \\
\hline IHEQN & Irish Higher Education Quality Network \\
\hline \multirow[t]{2}{*}{ ILEP } & Interim List of Eligible Programmes for Student Immigration \\
\hline & Permission \\
\hline INIS & Irish Naturalisation and Immigration Service \\
\hline IOM & International Organization for Migration \\
\hline $\mathrm{MRCl}$ & Migrant Rights Centre Ireland \\
\hline NFQ & National Framework of Qualifications \\
\hline NGO & Non-governmental organisation \\
\hline OECD & Organisation for Economic Cooperation and Development \\
\hline Oireachtas & Irish Parliament \\
\hline QQI & Quality and Qualifications Ireland \\
\hline RCSI & Royal College of Surgeons in Ireland \\
\hline STEM & Science, technology, engineering and maths \\
\hline STEP & Start-Up Entrepreneur Programme \\
\hline TFEU & Treaty on the Functioning of the European Union \\
\hline THEA & Technological Higher Education Association \\
\hline TLGP & Third Level Graduate Programme \\
\hline UCD & University College Dublin \\
\hline UK & United Kingdom \\
\hline
\end{tabular}


$\mathrm{ii} \mid$ Attracting and retaining international higher level students: Ireland

United States

USI

Union of Students in Ireland 


\section{EXECUTIVE SUMMARY}

International student mobility has grown significantly worldwide over the past two decades, increasing from two million to five million between 1999 and 2016 (OECD, 2018). The $\mathrm{EU}$ is one of the main destinations for international students, with 1.6 million international students enrolled in the EU in 2016 (OECD, 2018). The importance of attracting international students was most recently highlighted in EU Directive 2016/801 on the conditions of entry and residence of third-country nationals for the purpose of research, studies, training, voluntary service, pupil exchange schemes or educational projects and au pairing. ${ }^{1}$ While Ireland has not opted into the Directive, the publication of two international education strategies since 2010 and reform of the non-EEA student immigration framework reflect the importance now being attached to promoting the higher education of non-EEA students in Ireland. Immigration of non-EEA nationals for the purposes of higher education in Ireland grew by 45 per cent between 2013, when 9,325 first residence permits were issued to students, and 2017, when 13,519 such permits were issued. $^{2}$

This study examines policy, law and practice in Ireland relating to non-EEA students undertaking a full-time course of study leading to a higher education qualification in public and private third-level institutions. The study focuses on recent developments in policy on the internationalisation of higher education and changes to the student immigration framework that took place between 2012 and 2018. In particular, it looks at measures to attract non-EEA students to Ireland and retain those students following the completion of their studies. ${ }^{3}$ Non-EEA nationals enrolled in English language and further education programmes are outside the scope of this study.

\section{NON-EEA STUDENTS IN HIGHER EDUCATION IN IRELAND}

Two main sources of data exist on non-EEA students in Ireland: data on residence permits issued for study collected by the Garda National Immigration Bureau (GNIB) and the Irish Naturalisation and Immigration Service (INIS) and reported by

Recital (3) and (14).

Residence permits issued for the first time provide information on the 'flow' of non-EEA nationals coming to Ireland for the first time for study purposes. See: Eurostat, 'First permits issued for education reasons by reason, length of validity and citizenship' [migr_resedu], available at

http://appsso.eurostat.ec.europa.eu/nui/show.do?dataset=migr_resedu\&lang=en.

3 Retention for the purposes of the study relates to facilitating the stay of non-EEA students following completion of their studies, such as through measures to support access to the labour market. 
Eurostat; and data on enrolments in publicly funded higher education institutions (HEI) collected and reported by the Higher Education Authority (HEA).

A significant proportion of non-EEA nationals that migrate to Ireland each year do so to undertake higher education programmes. Of the 47,901 first residence permits issued in Ireland in 2017, 13,519 were issued for 'study' purposes to nonEEA nationals enrolled in a higher education programme. ${ }^{45}$ Some 25 per cent of these non-EEA nationals $(3,332)$ were from the US, 17 per cent $(2,300)$ were from India, 15 per cent were from Brazil $(2,041), 14$ per cent were from China $(1,870)$ and five per cent were from Canada (614). Available data on non-EEA student enrolments in full-time higher education programmes in public HEls show that the largest number of non-EEA students were enrolled in health and welfare courses, representing 31 per cent of all full-time non-EEA student enrolments. ${ }^{6}$ Non-EEA students were primarily concentrated in honours bachelor's degree $(7,894)$ and master's degree $(4,019)$ programmes in $2017 .^{7}$

\section{INTERNATIONAL EDUCATION POLICY}

Two policy strategies have formed the backbone of the government's strategic objectives with regard to international education. Ireland's first policy strategy, Investing in global relationships: Ireland's international education strategy 201015, was launched in 2010. The State's second (and current) strategy, Irish educated, globally connected: An international education strategy for Ireland 2016-2020, was published in 2016. The overall vision of the current strategy is 'to support Ireland to become internationally recognised for the development of global citizens through our internationalised education system and a market leader in attracting international student talent' (Department of Education and Skills, 2016a).

Higher education in Ireland is provided by over 40 HEls (Clarke et al., 2018), 23 of which are public HEls and a number of which are private colleges. Public HEls in Ireland include seven universities, one technological university, 11 institutes of technology and four colleges of education. A report commissioned by the HEA in 2018 to examine the development of internationalisation in HEls and the approaches adopted by HEls to attract and retain international students found that significant efforts have been made by HEls in the area of internationalisation (Clarke et al., 2018). HEls implemented a range of activities as part of their

4 Eurostat, 'First permits issued for education reasons by reason, length of validity and citizenship' [migr_resedu], available at http://appsso.eurostat.ec.europa.eu/nui/show.do?dataset=migr_resedu\&lang=en; Eurostat, 'First permits by reason, length of validity and citizenship' [migr_resfirst], available at http://appsso.eurostat.ec.europa.eu/nui/show.do?dataset=migr_resfirst\&lang=en.

5 Residence permits issued for the first time provide information on the 'flow' of non-EEA nationals coming to Ireland for the first time for study purposes.

Consultation with HEA, December 2018. Ibid. 
internationalisation strategies, including marketing plans targeted at specific countries/regions, conclusion of agreements and transnational provision of higher education. However, in the same report, some HEls observed that internationalisation efforts were constrained by a lack of resources.

Brexit has been highlighted as an opportunity to attract international students, who may have otherwise studied in the UK, to HEls in Ireland. Nevertheless, due to funding challenges and capacity constraints, this potential increase in international students has also been identified as a risk to the Irish higher education sector (Royal Irish Academy Brexit Taskforce, 2017).

\section{REGULATION OF NON-EEA STUDENT IMMIGRATION}

In addition to the international education strategies, reform of the non-EEA student immigration framework that took place in 2010 led to a more coherent national policy landscape for international students in Ireland.

Included in the first international education strategy was a commitment to introduce the International Education Mark (IEM) and a code of practice to ensure quality assurance standards in the international education sector (Department of Education and Skills, 2010). In 2015, Quality and Qualifications Ireland (QQI) published Code of practice for provision of programmes of education and training to international learners; however, as of May 2019, the IEM is yet to be introduced.

Further reforms were introduced in 2014 and 2015, in response to suspected misuse of the student migration route to access the labour market and to ensure a strong regulatory framework for developing the international education sector (Department of Education and Skills and Department of Justice and Equality, 2014; 2015). Reforms introduced included an enhanced inspection and compliance regime, revised conditions for accessing employment during and after studies and a more restrictive list of eligible programmes for student immigration purposes. Pending the introduction of the IEM, the Interim List of Eligible Programmes for Student Immigration Permission (ILEP) was established. The ILEP lists all higher education and English language courses that international students are permitted to pursue in Ireland for immigration purposes (Department of Education and Skills and Department of Justice and Equality, 2014; 2015).

\section{PROMOTION OF IRELAND AS A DESTINATION FOR NON-EEA STUDENTS}

The promotion and marketing of higher education study opportunities in Ireland is carried out under the Education in Ireland national brand. Managed by Enterprise Ireland, under the authority of the Department of Education and Skills, marketing and funding activity under Education in Ireland focuses on identified priority 
partner countries. Promotional activities include hosting and attending international education fairs, education missions and media and digital campaigns.

Scholarships are available to non-EEA students at governmental and institutional level. ${ }^{8}$ HEls, Enterprise Ireland and the Department of Foreign Affairs and Trade have also worked to develop and mobilise alumni abroad. However, HEls reported that Ireland is not well known in key markets due to the lack of a coordinated strategic effort at national level and lack of funding from the government for promotional activities (Clarke et al., 2018).

\section{ADMISSION CONDITIONS}

Non-EEA students are subject to a number of conditions when applying for a visa and/or residence permission. Non-EEA students are required to provide a letter of acceptance from their college confirming their enrolment on a full-time education course, as well as evidence of payment of HEI course fees, private medical insurance, English language proficiency and sufficient funds for the duration of studies. Residence permits granted to degree programme students are renewable up to a maximum of seven years, provided that the student in question progresses academically (INIS, 2011a)..$^{9}$ Requirements concerning the provision of health insurance to non-EEA students are the subject of ongoing court proceedings. ${ }^{10}$ Pending the outcome of an appeal, the situation relating to medical insurance costs is unclear and was reported as a challenge for HEls providing advice to international students. ${ }^{11}$ Stakeholders raised concerns about the difficulties faced by students in scheduling appointments to register or renew their residence permission at INIS. ${ }^{12}$ INIS is currently considering a range of options to improve the registration and renewal processes in advance of the 2019 student peak period of September to December. ${ }^{13}$

\section{ORIENTATION AND ACCOMMODATION SUPPORTS}

The HEA and Enterprise Ireland place great emphasis on the quality of the student experience as an important factor in attracting and retaining non-EEA students. ${ }^{14}$ $\mathrm{HEls}$ offer a range of supports to international students at institutional, faculty and

8 For further information on scholarships provided by various other HEls in Ireland, see: Education in Ireland, 'Scholarships', available at https://www.educationinireland.com/en/How-Do-I-Apply-/Tuition-CostsScholarships/Scholarships.

9 Exceptions can be made in cases where a programme is of such duration that it is not possible to finish it in seven years, or if there are special circumstances, such as illness (INIS, 2011a).

10 Chubb European Group PLC v The Health Insurance Authority [2018] IEHC 609.

11 Consultation with the IUA, December 2018; Consultation with THEA, December 2018.

12 Interview with ICOS, October 2018; Interview with Crosscare, October 2018.

13 Consultation with INIS, December 2018.

14 Interview with Enterprise Ireland, November 2018; Interview with HEA, November 2018. 
departmental level, including pastoral care supports (Clarke et al., 2018). Securing accommodation has been highlighted as one of the greatest challenges for international students by HEls and students themselves (McGuire, 2016; Fitzgerald, 2017; Clarke et al., 2018). Stakeholders note that privately developed, purpose-built student accommodation, which particularly targets international students, is being offered at an unaffordable price for many students (Fitzgerald, 2017; O'Brien, 2018a). ${ }^{15}$

\section{LABOUR MARKET ACCESS DURING AND AFTER STUDIES}

While recent reforms have sought to tighten the student immigration regime, Arnold at al. (2017) noted that working more than the maximum permitted working hours (20 per week during the academic term and 40 per week during holiday periods) is still a common feature of student immigration in Ireland. The non-governmental organisation (NGO) Migrant Rights Centre Ireland ( $\mathrm{MRCl}$ ) expressed the view that non-EEA students' immediate access to the labour market allows employers to circumvent restrictions on the issuing of work permits in lowpaid sectors ( $\mathrm{MRCl}, 2015$ ). $\mathrm{MRCl}$ found that non-EEA students availing of their service tend to be employed in part-time work in sectors in which they are particularly vulnerable to exploitation, including: hotel, restaurant and catering; service and retail; cleaning and maintenance; and domestic and care work (MRCl, 2015; Gilmartin et al., 2016).

The current strategy identifies highly skilled international students as a group making an important contribution to Ireland's talent pool. The Third Level Graduate Programme (TLGP) allows non-EU students at Level 8 of the National Framework of Qualifications (NFQ) and above to remain in Ireland following graduation for the purposes of seeking employment. Graduates at NFQ Level 8 are entitled to remain for one year, while graduates at NFQ Level 9 and above are entitled to remain for up to two years. At the end of this period, international graduates must have secured employment in order to continue residing in Ireland. The TLGP is viewed as a measure to both attract students to Ireland and retain students following graduation. ${ }^{16}$

Non-EEA students who do not qualify for the TLGP in Ireland may be granted permission to stay if they have secured employment through the employment permit system. Graduates can secure employment on the basis of a general employment permit, critical skills employment permit or research hosting agreement. Non-EEA students may alternatively be able to apply to set up a

15 ICOS, 'ICOS' response to National Student Accommodation Strategy', available at https://www.internationalstudents.ie/news/icos-response-national-student-accommodation-strategy.

16 Consultation with the HEA, December 2018. 
business through the Start-up Entrepreneur Programme. ${ }^{17}$ Since 2012, the number of international graduates who have secured an employment permit following graduation grew from 48 in 2013 to 871 in 2017.

\section{COOPERATION WITH NON-EEA COUNTRIES ON HIGHER EDUCATION}

Cooperation with third countries in the area of international students takes many forms, including bilateral and multilateral agreements signed by the State and HEls with governments and HEls in non-EEA countries. Irish HEls have also developed global relationships by establishing campuses overseas and offering programmes in partnership with institutions and providers abroad. Enterprise Ireland observed that institutional engagements worldwide continue to increase in line with the objectives of the current international education strategy. ${ }^{18}$

17 The Start-up Entrepreneur Programme (STEP) was introduced in January 2012 to attract third-country national entrepreneurs to Ireland and stimulate productive investment in the State. Third-country nationals with a proposal for a high potential start-up and funding of $€ 50,000$ may be given residency under STEP for the purposes of developing their business.

18 Interview with Enterprise Ireland, November 2018. 


\section{Introduction}

\subsection{OBJECTIVES AND BACKGROUND TO THE STUDY}

International student mobility has grown significantly over the past two decades. Between 1999 and 2016, the number of international students enrolled worldwide in tertiary education programmes grew by approximately 150 per cent, increasing from two million to five million. In 2016, 3.5 million international students were enrolled in tertiary programmes in OECD countries. The most popular OECD destination country for international students was the US, followed by the UK, Australia and Canada, which together accounted for over one-third of the international student population. Students from Asia represent the largest group (55 per cent) of international students enrolled in OECD tertiary education programmes (OECD, 2018).

International students represent a small fraction of the estimated 244 million migrants worldwide (IOM, 2018). Nonetheless, globalisation and increased connectivity have made education overseas more accessible, leading to a growth in demand for studies abroad (OECD, 2018). For host countries, international students may be an important source of income within the education sector and may contribute to the country's economic performance through participation in the labour market. For the students, studying abroad can provide them with access to education not on offer at home and improve their employability (OECD, 2018). For countries of origin, student mobility may be seen as lost talent, or 'brain drain'. However, it is also argued that the skills gained by international students can contribute to knowledge creation, which can benefit their home countries, or 'brain circulation', where highly educated students return to, or retain links with, their country of origin (OECD, 2008).

The EU is one of the main destinations for international students, with 1.6 million international students enrolled in the EU in 2016 (OECD, 2018). Many students studying in EU Member States come from another EU country; however, a significantly larger number are international students from outside the European Economic Area (EEA) (EMN, forthcoming). Increasing the number of international students forms an integral part of internationalisation, a working definition of which Knight (2015) suggests to be 'the process of integrating an international, intercultural or global dimension into the purpose, functions or delivery of postsecondary education'. This phenomenon has been particularly pronounced in EU countries, where policies to attract and retain international students are viewed as a means of addressing demographic changes in the EU and the demand for highly skilled labour (IOM, 2008). The importance of attracting international students was 
most recently highlighted in the EU's Directive 2016/801 on the conditions of entry and residence of third-country nationals for the purpose of research, studies, training, voluntary service, pupil exchange schemes or educational projects and au pairing (recast) (the 2016 Directive).${ }^{19}$

While Ireland has not opted into the 2016 Directive, the publication of two international education strategies since 2010 and reform of the student immigration framework reflect the importance that is being attached to promoting Ireland as a destination for international students. ${ }^{20}$ The number of non-EEA nationals arriving in Ireland to undertake a higher level course of study has grown significantly in recent years. Immigration of non-EEA nationals for the purposes of higher education in Ireland grew by 45 per cent between 2013, when 9,325 first residence permits were issued to students, and 2017, when 13,519 such permits were issued. ${ }^{21}$

This study examines policy, law and practice in Ireland relating to non-EEA students undertaking a full-time course of study leading to a higher education qualification in public and private third level institutions. It builds on the 2012 European Migration Network (EMN) study, Immigration of international students to the EU: Ireland, by focusing on recent developments in policies on internationalisation of higher education and changes to the student immigration framework. In particular, the study looks at measures to attract non-EEA students to Ireland and to retain them following graduation. ${ }^{22}$ Non-EEA nationals enrolled in English language and further education programmes are outside the scope of this study.

Section 1.2 of this chapter outlines the methodology adopted for the study, while Section 1.3 sets out the study's scope. Section 1.4 provides an overview of developments in law and policy relating to non-EEA students in addition to student immigration trends in the EU. The Irish policy context is presented in Section 1.5, followed by an overview of data on non-EEA students in higher education in Ireland. Chapter 2 discusses Ireland's international education policy framework in addition to recent reforms of the non-EEA student immigration. Chapter 3 examines the measures in place to promote Ireland as a destination for education and discusses the measures that facilitate the admission of non-EEA students to

19 Recital (3) and (14).

20 Protocol 21, annexed to the Treaty on the European Union and the Treaty on the Functioning of the European Union, provides that Ireland is exempt from participating in the adoption by the EU, and application of, measures in the area of Freedom, Security and Justice, unless it notifies the European Council and Commission of its wish to opt-in to such measures.

21 Residence permits issued for the first time provide information on the 'flow' of non-EEA nationals coming to Ireland for the first time for study purposes. See: Eurostat, 'First permits issued for education reasons by reason, length of validity and citizenship' [migr_resedu], available at

http://appsso.eurostat.ec.europa.eu/nui/show.do?dataset=migr_resedu\&lang=en.

22 Retention for the purposes of the study relates to facilitating the stay of non-EEA students following completion of their studies, such as through measures to support access to the labour market. 
Ireland. Chapter 4 addresses measures to retain international students following their studies. Chapter 5 provides an overview of cooperation between government and higher education institutions (HEIs) in Ireland and non-EEA countries.

\subsection{METHODOLOGY}

This report collates data and information on non-EEA international students in higher education in Ireland. It is based on information gathered according to commonly agreed EMN study specifications for the EU-wide study, Attracting and retaining international students in the EU. As with all EMN studies, a similar report was produced by the other EMN National Contact Points. An EU-wide synthesis report, which will collate information from all the national reports, will then be published (EMN, forthcoming).

Desk research was undertaken at the outset, including a review of existing academic and policy-based literature. Interviews were undertaken with officials from the Higher Education Authority (HEA), Enterprise Ireland, the Irish Council for International Students (ICOS) and Crosscare. Information was also obtained through correspondence with the Irish Naturalisation and Immigration Service (INIS), the Department of Business, Enterprise and Innovation, the Irish Universities Association (IUA), the Technological Higher Education Association (THEA) and the Higher Education Colleges Association (HECA). An online survey of higher education institutions in Ireland was held, to which two responded. Information was also sought from the Department of Education and Skills.

\subsection{DEFINITIONS AND SCOPE}

In referring to international students, Member States generally do not differentiate between students coming from a country outside the EU for the purpose of study and those coming from another EU country. The HEA refers to international students as all students that are domiciled outside of Ireland, thus including both EU and non-EU nationals. However, for the purposes of this study, and in order to facilitate comparison across EU Member States, an international student is defined in accordance with Article 3(3) of Directive 2016/801 as:

a third-country national who has been accepted by a higher education institution and is admitted to the territory of a Member State to pursue as a main activity a full-time course of study leading to a higher education qualification recognised by that Member State, including diplomas, certificates or doctoral degrees in a higher education institution, which may cover a preparatory course prior to such education, in accordance with national law, or compulsory training. 
The EMN Asylum and Migration Glossary 6.0 defines a third-country national as, '[a]ny person who is not a citizen of the European Union within the meaning of Art. 20(1) of TFEU and who is not a person enjoying the Union right to free movement, as defined in Art. 2(5) of the Regulation (EU) 2016/399 (Schengen Borders Code)'. ${ }^{23}$ Immigration of EU and EEA nationals for other education purposes are therefore excluded from the study. Reference to international students is limited to non-EEA nationals who migrate for the purposes of study.

Irish immigration requirements relating to international students differ according to whether the non-EEA national is a 'degree programme' student, enrolled on a higher education programme at Level 7 of the Irish National Framework of Qualifications (NFQ) and above, or a 'language or non-degree programme' student, enrolled in an English language course or higher education course between NFQ Level 6 and Level 7. The definition of an international student for the purposes of this study focuses on students enrolled in a higher education course of study only. Non-EEA nationals enrolled in an English language course are therefore outside the scope of the study.

The definition is also limited to third-country nationals enrolled in a full-time course of study; thus those enrolled in a part-time course and occasional students are excluded from the scope of the study. The study covers the period between 2013 to 2018, with statistics provided for the years 2013 to 2017.

\subsection{EUROPEAN POLICY CONTEXT}

The harmonisation of national laws governing the admission of third-country nationals for the purpose of education gained momentum in the EU in the early 1990s. In December 1991, the Council of the European Union adopted a report submitted by ministers responsible for immigration setting out a programme of work on the harmonisation of immigration and asylum policies, in which the admission of students was accorded high priority (Council of the European Union, 1991). In November 1994, the Council of the European Union then adopted a resolution on the admission of third-country nationals to the territory of the Member States for study purposes. In particular, the resolution stated that the duration of residence for students should be limited to the length of their course of study and that students may not engage in gainful employment, with the exception of short-term or subsidiary jobs (Council of the European Union, 1994). In a subsequent communication on asylum and immigration policy, the European Commission stated admission policies should be based on the idea that migration for study promotes better understanding and knowledge of other societies, while

23 According to this definition, nationals of Norway, Iceland, Liechtenstein and Switzerland are not considered to be thirdcountry nationals. 
also highlighting the need to avoid policies that create a 'brain-drain' effect on countries of origin (Commission of the European Communities, 1994).

While harmonisation was being looked to as a necessary step in order to promote the EU as a destination for studies, moves towards enhancing cooperation in the provision of higher education across wider Europe were also underway. In May 1998, the education ministers of France, Germany, Italy and the UK signed the inter-governmental Sorbonne Declaration, which included a set of voluntary commitments on the harmonisation of the architecture of a European higher education system. ${ }^{24}$ The Declaration called on other EU Member States and European countries to join them in their objectives and, in June 1999, the ministers of education of 29 European countries, including Ireland, signed the Bologna Declaration. ${ }^{25}$ While the Bologna Declaration developed as an inter-governmental process separate to that of the EU, the EU emphasises its role in supporting countries to drive the aims of the Declaration (European Union, 2018). The Bologna Declaration includes a number of voluntary commitments to achieve greater compatibility and comparability between systems of higher education and to increase the competitiveness of higher education in European countries. The Declaration launched the Bologna intergovernmental process, which set the foundation for the establishment of the European Higher Education Area (EHEA) in 2010. In order to establish the EHEA, the Declaration set out a number of objectives, including the adoption of a framework of comparable degrees, the existence of undergraduate and postgraduate cycles in all countries, establishment of a system of credits, cooperation in quality assurance and elimination of obstacles to student mobility. Since the adoption of the Declaration, 48 European countries, including all 28 EU Member States, have joined the Bologna process.

Cooperation within the EU, through the Erasmus programme, which seeks to enhance the quality and attractiveness of higher education in Europe, also contributed to the internationalisation of higher education. ${ }^{26}$ Launched in 1987 to facilitate student exchange among EU Member States, the Erasmus programme has since expanded to facilitate third-country nationals to obtain educational qualifications in the EU. ${ }^{27,28}$ The Irish government has emphasised that Ireland's

24 EHEA, 'Sorbonne Joint Declaration', available at http://www.ehea.info/media.ehea.info/file/1998_Sorbonne/61/2/1998_Sorbonne_Declaration_English_552612.pdf.

25 EHEA, 'The Bologna Declaration of 19 June 1999', available at http://www.ehea.info/media.ehea.info/file/Ministerial_conferences/02/8/1999_Bologna_Declaration_English_553028 .pdf.

26 Regulation (EU) No 1288/2013 of the European Parliament and of the Council of 11 December 2013 establishing 'Erasmust': The Union programme for education, training, youth and sport and repealing Decisions No 1719/2006/EC, No $1720 / 2006 /$ EC and No 1298/2008/EC.

27 Council decision of 15 June 1987 adopting the European Community Action Scheme for the Mobility of University Students (Erasmus) (87/327/EEC).

28 Decision No. 2317/2003/EC of the European Parliament and of the Council of 5 December 2003 establishing a programme for the enhancement of quality in higher education and the promotion of intercultural understanding through cooperation with third countries (Erasmus Mundus) (2004 to 2008). 
involvement in the Erasmus programme since 1987 has been crucial to the internationalisation of education in Ireland (Department of Education and Skills, 2010).

In the context of an increased focus on the internationalisation of education at EU level, the adoption of the Treaty of Amsterdam in 1999 established the EU's competence to adopt legislation in the area of migration and asylum, which led to EU-led efforts to harmonise Member State approaches to student immigration. In December 2004, the Council of the European Union adopted Directive 2004/114/EC on the conditions of admission of third-country nationals for the purposes of studies, pupil exchange, unremunerated training or voluntary service (the 2004 Directive). The aim of the 2004 Directive was to harmonise laws in EU Member States on conditions for admitting international students, as part of the EU's objective to promote the mobility of third-country nationals for education. The Directive highlighted that migration for the purpose of studies is by definition temporary and a form of mutual enrichment for migrants, their country of origin and the host Member State. While the Commission pointed out that Member States increasingly sought to retain students by providing opportunities to students to remain after their studies in order to remedy skills shortages, flanking measures were required to minimise any 'brain drain' from students' countries of origin (European Commission, 2002). The 2004 Directive provided that students were entitled to employment for a minimum of 10 hours per week. Labour market access was considered necessary to reflect the cost of studies; however, access was made subject to certain conditions in order to ensure education was preserved as the primary objective of stay (European Commission, 2002).

In its 2011 review of the 2004 Directive's implementation, the Commission concluded that the level of harmonisation achieved was weak, as many of its provisions did not contain specific obligations for Member States, and that international students still faced obstacles coming to the EU to study (European Commission, 2011). In 2012, the previous EMN study on international students found that a harmonisation of the conditions for admitting international students to EU Member States had taken place to a certain extent, but that differences could still be observed at national level. This was particularly true in relation to labour market access and rights afforded to international students during their stay (EMN, 2013). The Stockholm Programme, which provided a framework for EU action in relation to migration and asylum from 2010 to 2014, also emphasised that access to Europe for students, among others, should be made more effective and efficient (Council of the European Union, 2010).

The recast Directive 2016/801 of 11 May 2016, on the conditions of entry and residence of third-country nationals for the purposes of research, studies, training, voluntary service, pupil exchange schemes or educational projects and au pairing, 
(the 2016 Directive) was subsequently adopted. This reform repealed and replaced the 2004 Directive. The 2016 Directive also merges the 2004 Directive with provisions on researchers at EU level that were contained in Directive 2005/71/EC of 12 October 2005, which concerned a specific procedure for admitting thirdcountry nationals for the purposes of scientific research. While Ireland opted into the latter, Ireland, the UK and Denmark did not opt into the 2004 or 2016 Directives.

The Commission in its proposal highlighted the potential of international students to form part of a pool of highly-skilled workers that can address challenges posed by the changing EU working-age population and future skills shortages. The Commission noted that the possibility to remain in a Member State following their studies is an important factor for international students pursuing studies in the EU and that this contributes to increasing the EU's global competitiveness in attracting talent (European Commission, 2013). It also noted that allowing third-country nationals to acquire knowledge and skills in Europe encourages 'brain circulation' and benefits both the country of origin and destination (European Commission, 2011). These factors are reflected in the provisions of the 2016 Directive. In particular, new provisions relate to increasing the rights of students to work parttime from a minimum of ten hours per week to 15 hours per week (Article 24) and permitting students to stay for a period of at least nine months after completion of their studies to identify work opportunities, subject to certain conditions (Article 25).

\subsubsection{Overview of main trends regarding non-EEA students in EU Member States}

\section{Immigration flows of non-EEA students in EU Member States}

At EU level, data are collected by Eurostat on the number of first residence permits issued for reasons relating to family, education and employment. Data on first residence permits issued for education reasons include two sub-categories. Firstly, permits for 'study' are issued to students enrolled in higher education programmes as defined under the Directives relating to non-EEA students (see Section 1.3). Secondly, permits for 'other educational reasons' are issued to non-EEA nationals not covered by the student definition, such as those admitted as English language students, unremunerated trainees or volunteers. ${ }^{29}$

Figure 1.1 shows that the number of third-country nationals arriving in EU Member States for education purposes gradually increased between 2013 and 2017. The

29 Eurostat, 'Statistics on resident permits - The main definitions and methodological concepts', available at https://ec.europa.eu/eurostat/cache/metadata/Annexes/migr_res_esms_an5.pdf. 
number of first-residence permits issued for education-related reasons increased

by 14 per cent between $2013(463,943)$ and $2017(530,113)$.

FIGURE 1.1 FIRST RESIDENCE PERMITS ISSUED IN EU MEMBER STATES, 2013-2017

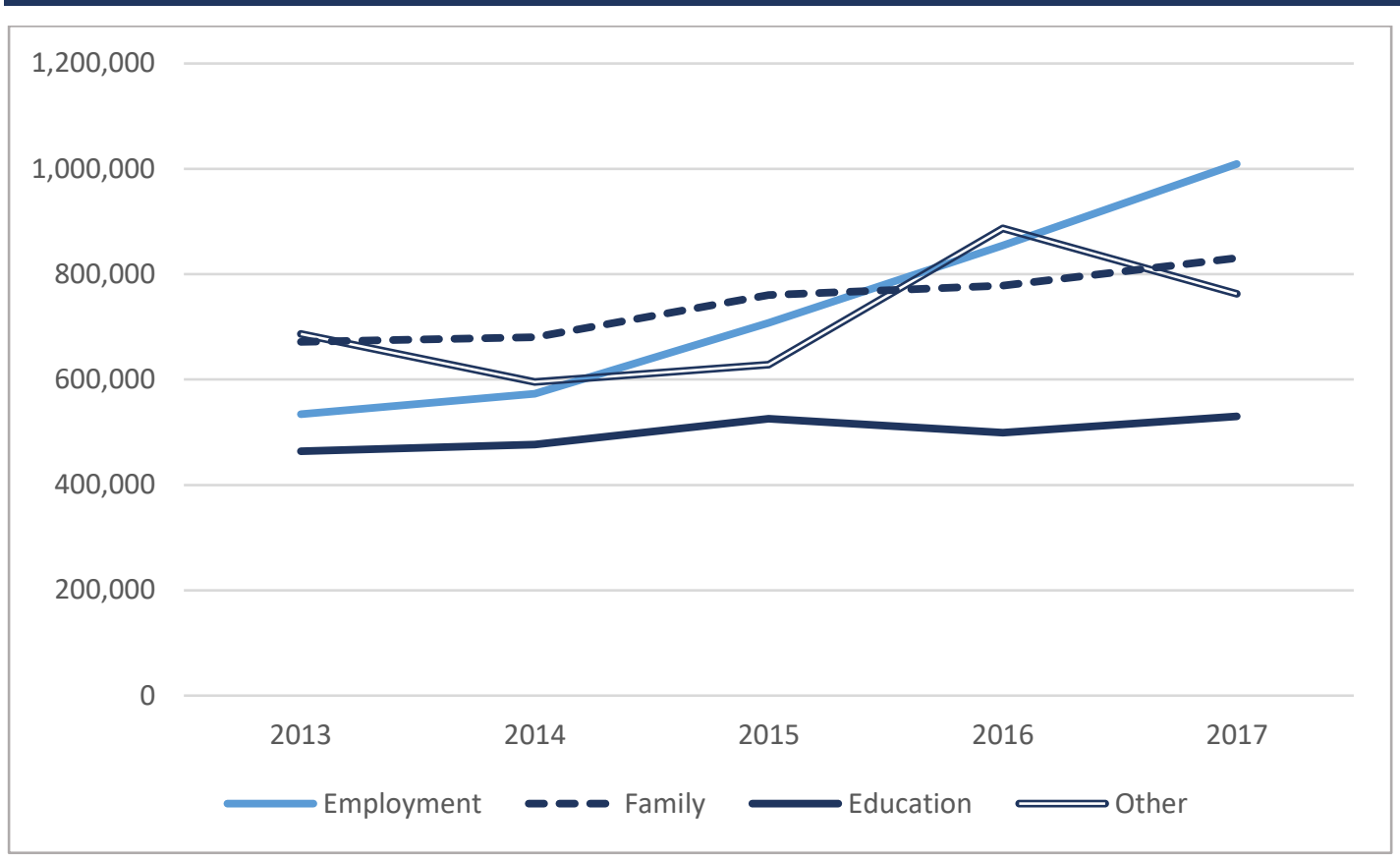

Source: Eurostat, 'First permits by reason, length of validity and citizenship' [migr_resfirst],

http://appsso.eurostat.ec.europa.eu/nui/show.do?dataset=migr_resfirst\&lang=en.

In 2017, 3,132,972 first-residence permits were issued to third-country nationals in EU Member States. Figure 1.1 shows that of the four categories, educationrelated permits accounted for the lowest number of these first-residence permits issued in EU Member States, each year between 2013 and 2017. The highest number of first-residence permits issued in EU Member States were issued for employment-related reasons ( 32 per cent), followed by family-related reasons ( 27 per cent), other reasons ( 24 per cent), ${ }^{30}$ and education-related reasons (17 per cent).

Figure 1.2 shows the proportion of first permits issued to non-EEA nationals for education reasons, broken down into 'study' and 'other educational reasons' categories. It shows that the majority of residence permits issued in EU Member States for education reasons are issued to international students as defined under the Directives (four EU Member States do not disaggregate data on education permits between 'study' and 'other educational reasons' categories). ${ }^{31}$ Of the

30 'Other reasons' may include residence without the right to work or international protection. The types of permission included in this category may differ across Member States. See: Eurostat, 'Residence permits - statistics on first permits issued during the year', available at https://ec.europa.eu/eurostat/statisticsexplained/index.php?title=Residence_permits_\%E2\%80\%93_statistics_on_first_permits_issued_during_the_year.

31 Bulgaria, Finland, France, and the UK. 
530,113 first-residence permits issued for education reasons in the EU in 2017, 87 per cent $(460,694)$ were issued for study.

FIGURE 1.2 PERCENTAGE OF FIRST-RESIDENCE PERMITS ISSUED FOR STUDY AND OTHER EDUCATIONAL REASONS OUT OF TOTAL FIRST PERMITS IN EU MEMBER STATES, 2017

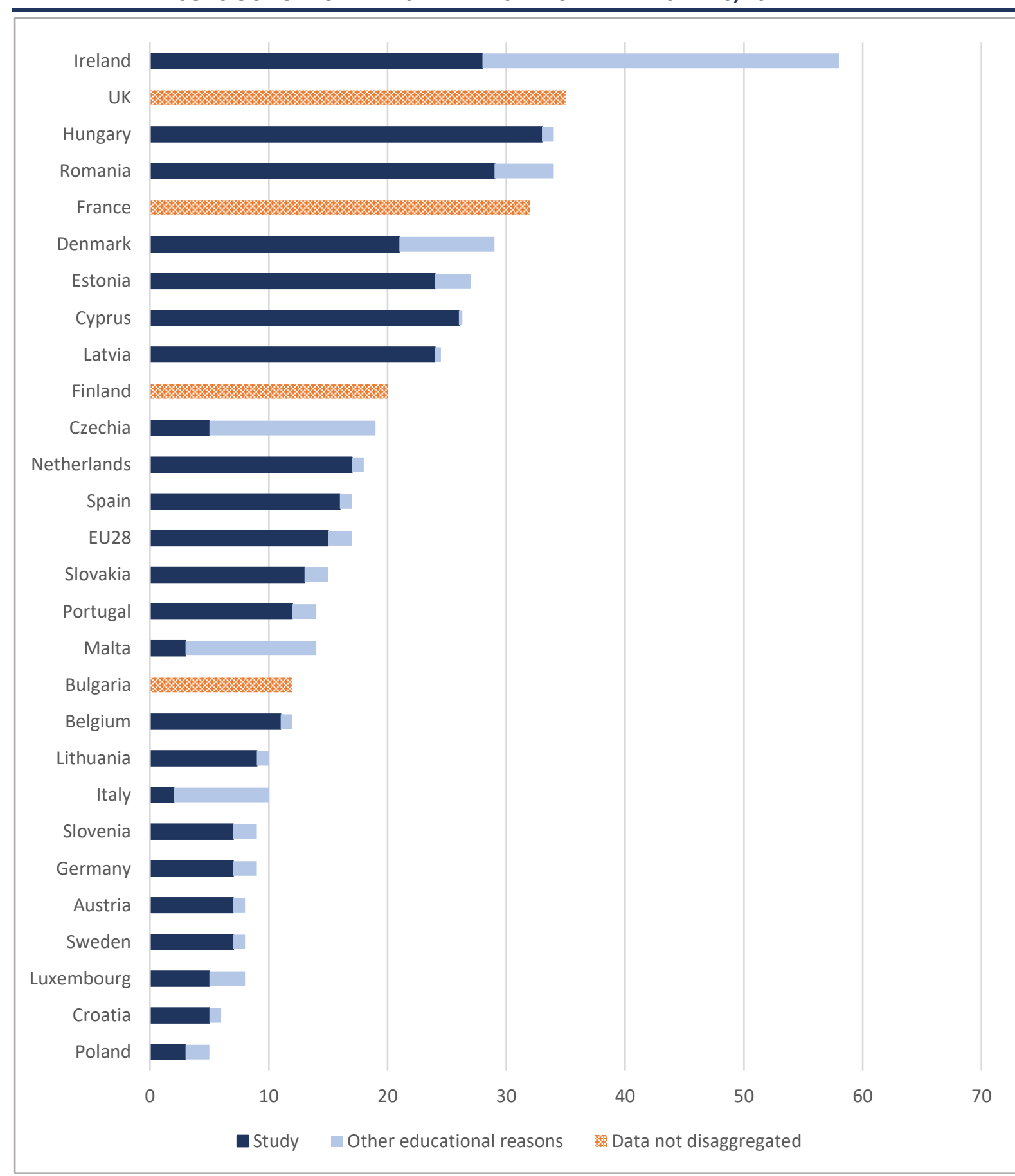

Source: Eurostat, 'First permits issued for education reasons by reason, length of validity and citizenship' [migr_resedu], http://appsso.eurostat.ec.europa.eu/nui/show.do?dataset=migr_resedu\&lang=en; Eurostat, 'First permits by reason, length of validity and citizenship' [migr_resfirst]

http://appsso.eurostat.ec.europa.eu/nui/show.do?dataset=migr_resfirst\&lang=en.

Unlike most other EU Member States, education-related reasons account for the highest proportion of all first residence permits issued in Ireland in 2017. Of all first 
permits issued to non-EEA nationals in Ireland, 58 per cent were issued for education reasons. Romania and the UK were the only other EU Member States in which the most common reason for issuing a first-residence permit was related to education, at 34 per cent and 35 per cent respectively.

Figure 1.2 shows that the proportion of first-residence permits issued for education-related reasons that are issued specifically for 'other educational reasons' (i.e. not 'study') is larger in Ireland than in most other EU Member States (see Section 1.5.1). Four other EU Member States (the Czech Republic, Greece, Italy and Malta) reported higher numbers of non-EEA nationals granted first-residence permits for 'other educational reasons' compared to those granted for 'study'. Malta noted that permits granted for 'other educational reasons' are granted to non-EEA nationals enrolled in English language schools. ${ }^{32}$

As shown in Figure 1.3, the highest number of residence permits issued to students in 2017 was recorded in the UK, where 179,633 such permits were issued, representing 39 per cent of all first-residence permits issued to students in the EU. France reported the second highest number of permits issued for study $(80,566)$, followed by Germany $(39,546)$, Spain $(37,531)$ and Poland $(21,579)$. Ireland reported the seventh highest number of permits issued for study reasons out of all EU Member States, with 13,519 permits issued in 2017, representing three per cent of all permits issued for study reasons in the EU.

32 Eurostat, 'First permits completeness', available at https://ec.europa.eu/eurostat/cache/metadata/Annexes/migr_res_esms_an2.pdf. 


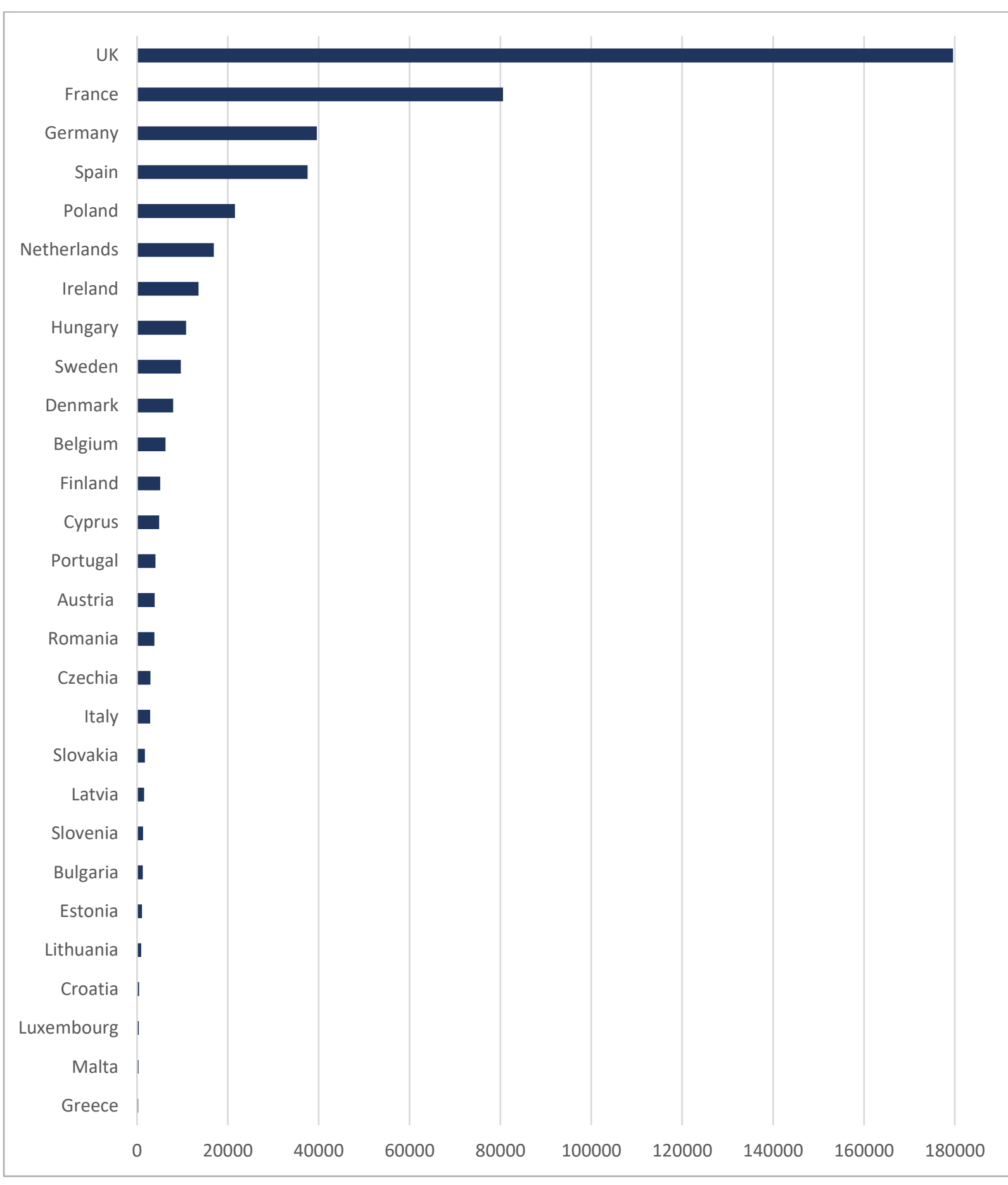

Source: Eurostat, First permits issued for education reasons by reason, length of validity and citizenship [migr_resedu], http://appsso.eurostat.ec.europa.eu/nui/show.do?dataset=migr_resedu\&lang=en.

Note: Bulgaria, Finland, France and the UK do not disaggregate between permits issued for 'study' and 'other educational reasons'.

In 2017, the largest share (26 per cent, or 119,103) of first-residence permits for study in the EU were issued to nationals of China. The second largest share were issued to nationals of the US $(33,417$, or seven per cent), followed by India $(32,372$, 
or seven per cent), Ukraine $(16,354$, or four per cent) and Morocco $(13,257$, or three per cent).

\section{Enrolments in higher education in EU Member States}

Figure 1.4 shows the proportion of non-EEA nationals and EU nationals among the higher education student population in each EU Member State that reported data on international students in the EMN study (EMN, forthcoming).

FIGURE 1.4 PROPORTION OF NON-EEA AND EU STUDENTS AMONG TOTAL STUDENTS IN HIGHER EDUCATION IN EU MEMBER STATES, 2016

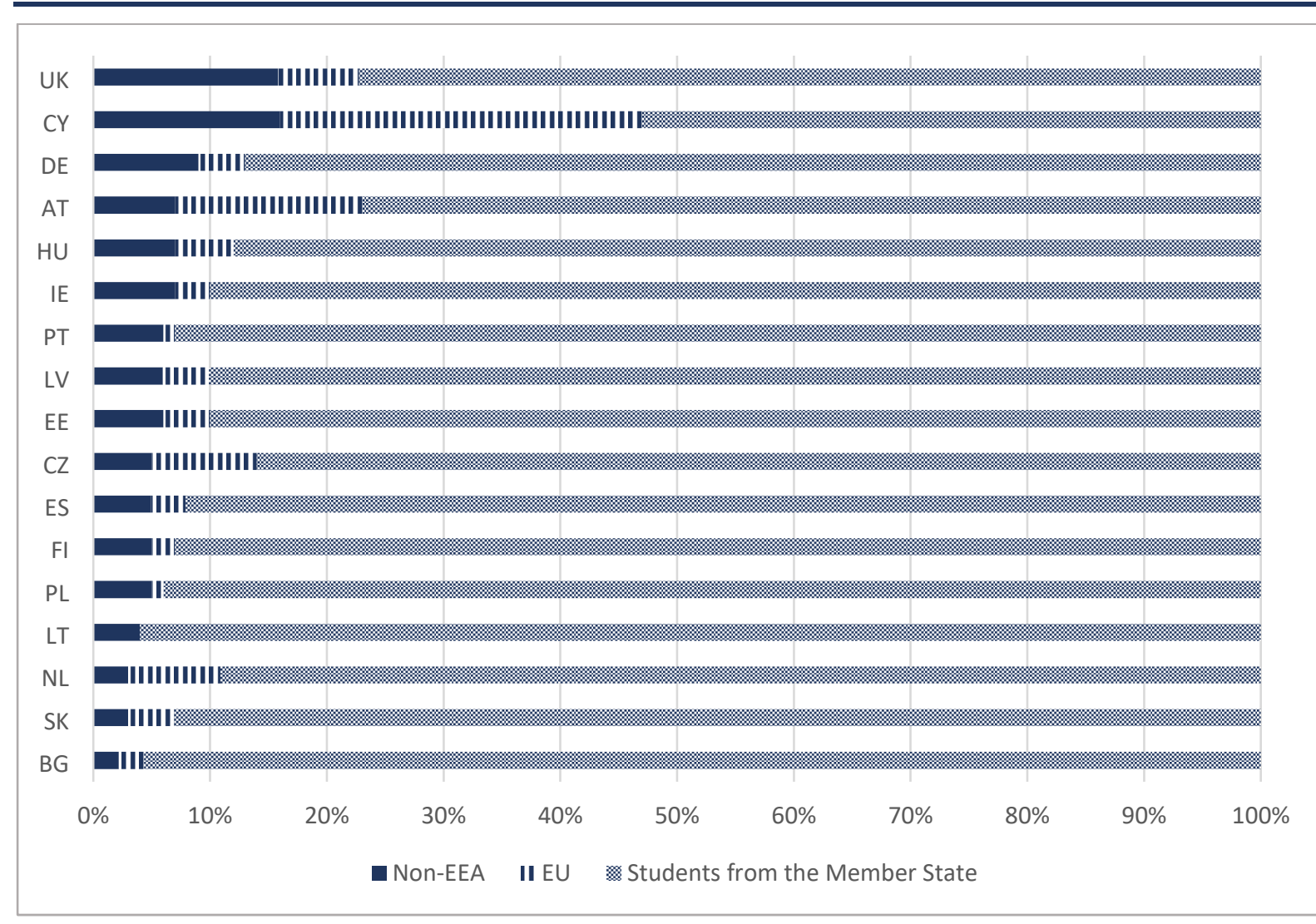

Source: $\quad$ European Migration Network (forthcoming)

Note: $\quad$ A range of national data sources are used. HEA data is used for Ireland, which excludes all private HEIs.

Member State codes: UK, United Kingdom; CY, Cyprus; CZ, the Czech Republic; DE, Germany; AT, Austria; HU, Hungary; IE, Ireland; PT, Portugal; LV, Latvia; PL, Poland; FI, Finland; ES, Spain; SK, Slovakia; NL, the Netherlands; BG, Bulgaria; LT, Lithuania.

Non-EEA nationals represent the majority of non-national students in most Member States, EU students outnumbering non-EEA students only in Austria, Cyprus, the Netherlands and Slovakia. The UK reported the largest proportion (17 per cent) of non-EEA national students among the student population in higher education, followed by Cyprus (16 per cent) and Germany (nine per cent). Ireland was joint fourth in this scale with Austria and Hungary. In Ireland, non-EEA students represented seven per cent of the full-time higher education student population in 2016. 


\subsection{IRISH POLICY BACKGROUND}

As stated in Section 1.2, Ireland has not opted into either the 2004 or 2016 EU Directive relating to non-EEA students. However, many of the conditions applicable to non-EEA nationals arriving in Ireland for the purposes of study mirror those set out in the Directive's provisions (EMN, forthcoming) (see Section 3.2.1).

In light of the growing global demand for higher education, and on request of the then Minister for Education and Science, the government established an interdepartmental Working Group to examine the internationalisation of education in Ireland in 2003. In a report to government in 2004, the Working Group recommended that a coherent approach to developing the international education market should be adopted (Department of Education and Science, 2004). The report was followed by a number of changes to the provision of higher education to international students in Ireland, including the establishment in 2009 of a new coordinated framework for the promotion, regulation and coordination of international education.

Included in the Working Group's recommendations was the development of a code of practice for higher education providers offering programmes to international students and a quality mark that would be awarded to education providers that comply with the code of practice (Department of Education and Science, 2004; Department of Education and Skills, 2010). The quality mark was viewed as a means of enhancing Ireland's reputation as a destination for international students and as a key indicator for immigration authorities assessing visa and residence permission applications from non-EEA nationals entering Ireland to pursue studies in a recognised HEI (Irish Naturalisation and Immigration Service, 2010). Responsibility for establishing the code of practice and the quality mark, otherwise known as the International Education Mark (IEM), was assigned to Qualifications and Quality Ireland (QQI), the amalgamated state agency established in 2012 to promote quality and accountability in education and training services. ${ }^{33}$ The Code of practice for provision of programmes of education and training to international learners was published in 2015 (see Chapter 2). It was initially planned that applications for the IEM would be taken from January 2015; however, as of May 2019, the IEM is yet to be introduced (see Chapter 2). Pending the IEM's introduction, the Department of Education and Skills and Department of Justice and Equality introduced an Interim List of Eligible Programmes for Student Immigration Permission (ILEP), which lists all higher education and English language courses that international students are permitted to pursue in Ireland for immigration purposes (see Chapter 2).

33 Qualifications and Quality Assurance (Education and Training) Act 2012, as amended, ss 60-61. 
In 2009, Enterprise Ireland, a state agency responsible for the development and growth of Irish enterprises in world markets, was charged with a key role in relation to the promotion of Ireland as a destination for higher education under the national brand 'Education in Ireland'. Before then, this had been a function of the International Education Board of Ireland, since 1992 (Finn and O'Connell, 2012). The (ongoing) High Level Group on International Education was also established in 2009 to coordinate national policy on international education and develop an international education strategy for Ireland. The Group is chaired by the Department of Education and Skills and brings together representatives of government departments and state agencies, the university sector, technological higher education sector, private colleges and English language sectors, and student representative bodies (Department of Education and Skills, 2010). ${ }^{34}$

Ireland's first international education strategy, Investing in global relationships: Ireland's international education strategy 2010-15, was adopted in September 2010. The primary objective of the strategy was that Ireland would become 'internationally recognised and ranked as a world leader in the delivery of highquality international education by providing a unique experience and long-term value to students' (Department of Education and Skills, 2010). Key objectives and targets relating to non-EEA students in higher education included increasing the number of full-time international students in higher education, enhancing the economic impact of international education to approximately $€ 1.2$ billion by 2015 and strengthening institutional relationships with priority partner countries. Underpinning the strategy's key objective and targets were ten strategic actions to enhance Ireland's competitive position in the provision of international education (see Chapter 2) (Department of Education and Skills, 2010).

The introduction of the first international education strategy was launched as part of a whole-of-government approach, in tandem with a number of reforms to regulations governing immigration to Ireland for education purposes. ${ }^{35}$ Prior to 2011, non-EEA student immigration in Ireland was not as tightly regulated as it is today, and student immigration was not monitored (Finn and O'Connell, 2012). As in other EU Member States, the misuse of the non-EEA student immigration regime as a means of entering and residing in the country for purposes other than education was identified as a challenge (EMN, 2013; Finn and O'Connell, 2012; INIS, 2009). As part of the overhaul of Ireland's international education system, the government launched a review of the student immigration framework in 2009

34 Department of Education and Skills, 'High Level Group on International Education', available at https://www.education.ie/en/The-Department/Regulation-of-Lobbying-Act-2015/Groups-Committees-exemptedunder-the-Transparency-Code/High-Level-Group-on-International-Education.html.

35 Department of Education and Skills, 'Government launches new strategy to dramatically expand international student numbers', press release, 22 September 2010, available at https://www.education.ie/en/Press-Events/PressReleases/2010-Press-Releases/PR10-09-22.html. 
(INIS, 2009)..$^{36}$ Following a public consultation, the Inter-Departmental Committee on Non-EEA Student Immigration established to oversee the review, published a set of recommendations in 2010 that formed the basis of the new immigration regime introduced in January 2011 (INIS, 2010; 2011b). The new regime included the creation of a differentiated approach to student immigration, divided between 'degree programme' non-EEA students and 'language or non-degree programme' non-EEA students. Other reforms included the introduction of capped periods of time a non-EEA student can spend in Ireland and stricter criteria for students applying for, and renewing, a residence permit (see Chapter 3 ). At the same time, policy measures that had previously been introduced to attract and retain non-EEA students, such as the Third Level Graduate Programme (TLGP, see Chapter 4), were further expanded. The first strategy noted that the reforms introduced would strengthen Ireland's competitiveness in the area of international education (Department of Education and Skills, 2010). Further reforms have since been implemented, as set out in policy documents and statements published in 2014 and 2015 by the Department of Justice and Equality and Department of Education and Skills (see Chapter 2) (Department of Education and Skills and Department of Justice and Equality, 2014; Department of Education and Skills and Department of Justice and Equality, 2015).

Ireland's current international education strategy, Irish educated, globally connected: An international education strategy for Ireland 2016-2020, which was developed by the Department of Education and Skills following consultations with a wide range of stakeholders, was published in October 2016. The strategy includes a review of the implementation of the first strategy, which noted that targets set out in the first strategy to increase full-time international students and the economic impact of international education had been exceeded. The current strategy builds on progress made following the first strategy and sets out strategic actions to further the internationalisation of education in Ireland over a five-year period (see Chapter 2) (Department of Education and Skills, 2016a).

\subsubsection{Overview of trends in relation to non-EEA students in Ireland}

Two main sources of data exist on trends in non-EEA students in Ireland: data on residence permits issued for study collected by the Garda National Immigration Bureau (GNIB) and the Irish Naturalisation and Immigration Service (INIS) and reported by Eurostat; and data on enrolments in publicly funded HEls collected and reported by the HEA.

36 Department of Justice and Equality, 'Ahern to overhaul student immigration regime', press release, 1 September 2009, available at http://www.justice.ie/en/JELR/Pages/Ahern\%20to\%20overhaul\%20student\%20immigration\%20regime. 


\section{Immigration of non-EEA students}

As set out in Section 1.4.1, data on first-residence permits issued for education reasons include two sub-categories. The first category of permits are those issued for 'study' to students enrolled in higher education programmes as defined under the Directives relating to non-EEA students. The second category are issued for 'other educational reasons' to non-EEA nationals not covered by the student definition, such as those admitted as English language students or students enrolled in vocational training courses. ${ }^{37}$

The upward trends in residence permits issued to non-EEA higher education students reflect in part the renewed policy focus in encouraging such students to study in Ireland.

Figure 1.5 presents immigration rates of non-EEA nationals to Ireland under four categories. The categories reflect the number of first permits issued. The data show that first-residence permits issued for education-related reasons increased by 30 per cent overall between 2013 and 2017. Education-related reasons accounted for the highest proportion of all first-residence permits issued in Ireland between 2013 and 2017. Of the 47,901 first-residence permits issued in Ireland in 2017, 27,588 (58 per cent) were for education-related reasons. In the same year, 9,398 permits (20 per cent) were issued for employment-related reasons, 7,857 (16 per cent) for other reasons and 3,058 (six per cent) for family reasons. In 2017, education thus accounts for more first-residence permits than the other three categories combined. 


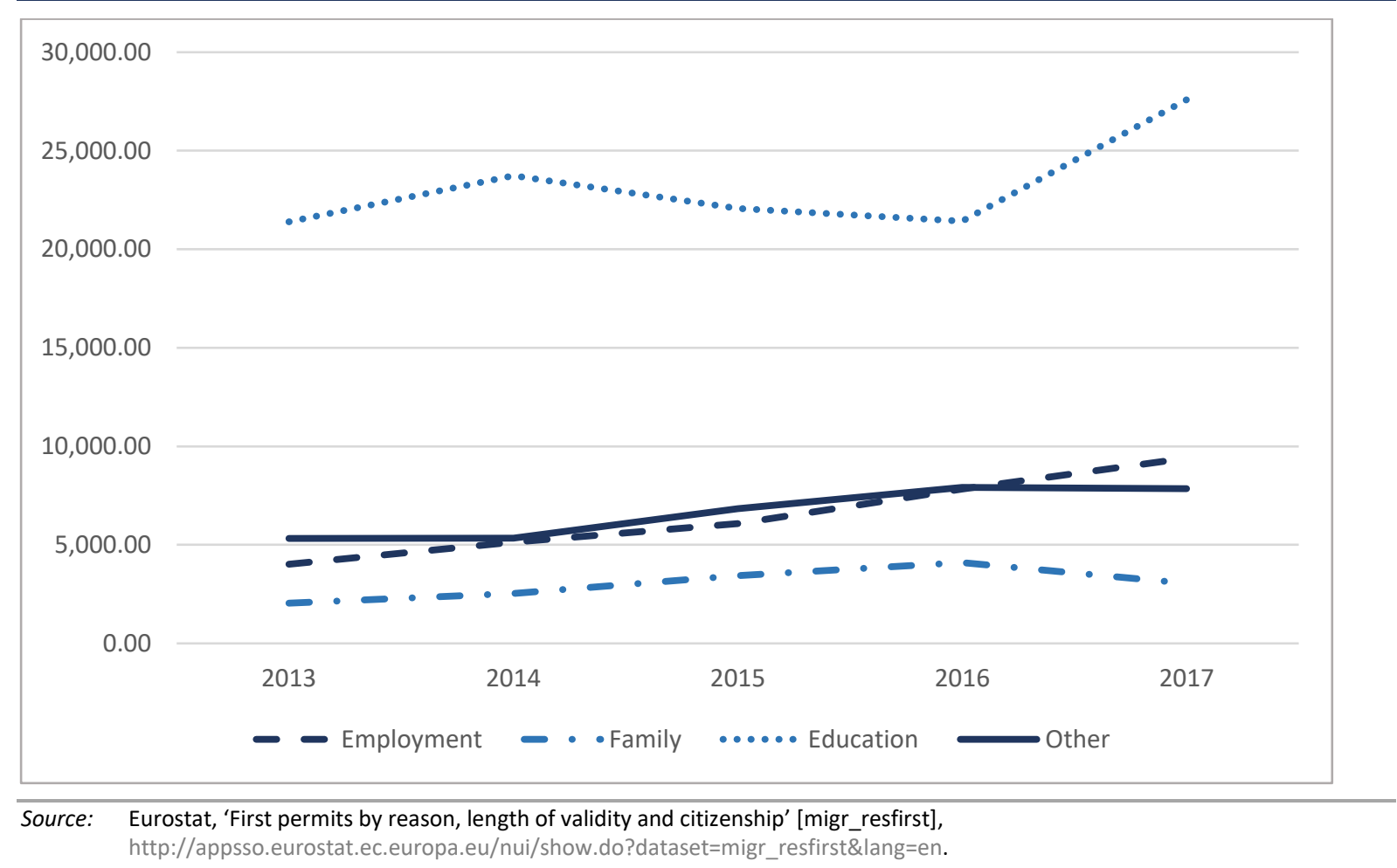

Figure 1.6 shows that in each year, apart from 2016, a larger number of firstresidence permits were issued for 'other educational reasons' than for 'study'. In 2017, 14,069 first-residence permits were issued for 'other educational reasons', while 13,519 such permits were issued for 'study' purposes. The higher number of non-EEA nationals granted a first-residence permit for 'other educational reasons' may partly reflect the larger number of non-EEA nationals in Ireland who are enrolled in English language courses rather than in higher education. Marketing English in Ireland, an association of regulated English Language Schools in Ireland, reported that in 2017 approximately 33,250 non-EEA nationals were enrolled in English language courses across the 66 regulated English language schools and colleges in Ireland. ${ }^{38}$

38 Marketing English in Ireland, '8\% rise in international English language students studying in Ireland with numbers now over 129,000', available at https://mei.ie/8-rise-in-international-english-language-students-studying-in-ireland-withnumbers-now-over-129000/. 


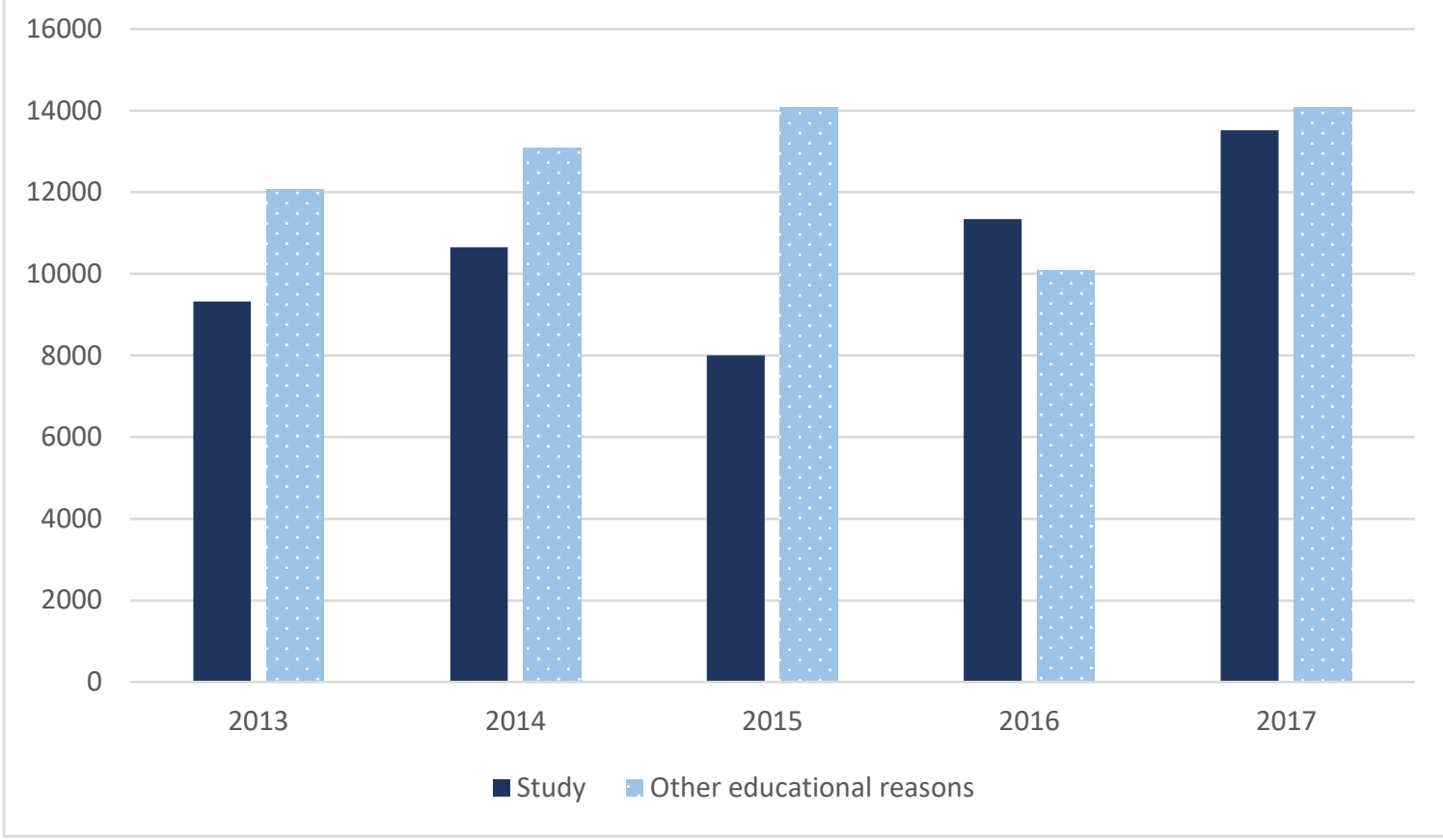

Source: Eurostat, 'First permits issued for education reasons by reason, length of validity and citizenship' [migr_resedu], http://appsso.eurostat.ec.europa.eu/nui/show.do?dataset=migr_resedu\&lang=en.

Among students issued a first-residence permit for study in a full-time higher education programme in Ireland in 2017, 25 per cent $(3,332)$ were from the US, 17 per cent $(2,300)$ were from India, 15 per cent were from Brazil $(2,041), 14$ per cent were from China $(1,870)$ and five per cent were from Canada (614).

\section{Student enrolments in higher education}

Comprehensive data on enrolments of non-EEA students in higher education are not available in Ireland. While comprehensive and up-to-date data are collected at national level by the HEA on students enrolled in HEA-funded HEIs, data on students in private HEls are not collected at national level. Data on enrolments in private HEls, as well as enrolments in Irish campuses or joint programmes overseas, had previously been gathered by Enterprise Ireland in its annual Education in Ireland report; however, this report series was discontinued in $2012 .{ }^{39}$

Given that available data on international students do not cover the international education sector in its entirety, and as this study only focuses on non-EEA students enrolled in full-time higher education programmes, the data provided do not seek to draw definitive conclusions regarding the number of non-EEA students studying

39 For an outline of international student data sources, see ICOS, 'Statistics', available at https://www.internationalstudents.ie/policy/statistics-international-students-ireland. 
in Ireland. Rather, these data provide a snapshot of non-EEA student full-time enrolments in higher education in public HEls in Ireland.

Figure 1.7 shows that the majority of students from outside Ireland who are enrolled in full-time higher education programmes in public HEls in Ireland come from outside of the EEA. Of the 166,640 students enrolled in the 2013-2014 academic year, six per cent were from a non-EEA country of origin. The proportion of students from non-EEA countries has grown steadily each year, with this group accounting for eight per cent of 180,044 total full-time enrolments in the 20172018 academic year. In contrast, the proportion of the student body represented by EU students remained static during that period, only growing by 0.1 percentage point overall between 2013 and 2017.

FIGURE 1.7 STUDENTS ENROLLED IN FULL-TIME HIGHER EDUCATION PROGRAMMES IN PUBLIC HEIS BY DOMICILIARY OF ORIGIN, 2013-2017

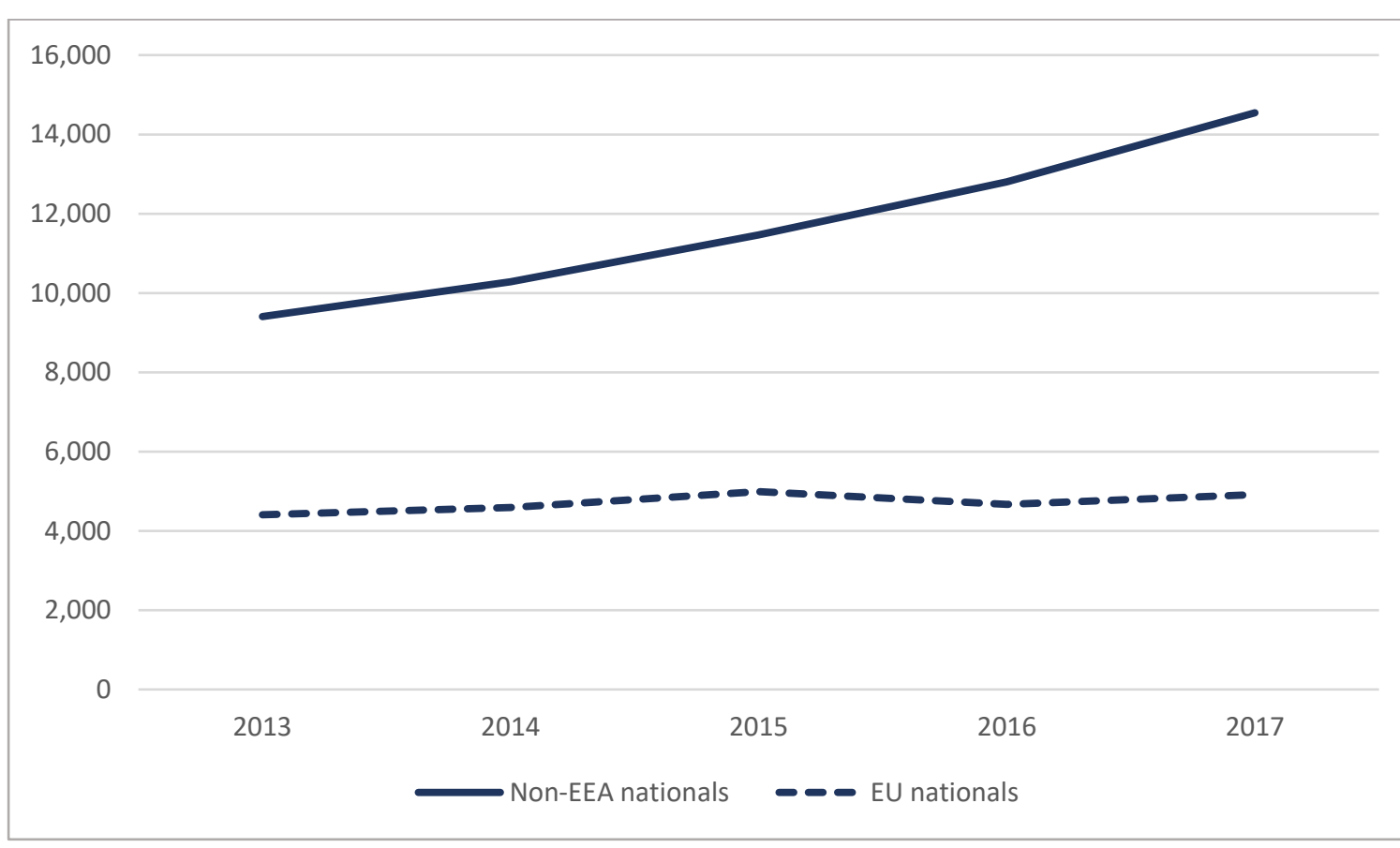

Source: Consultation with HEA, December 2018.

Note: The HEA collects data on a student's domiciliary of origin, which is the student's country of permanent residence prior to entry into the course of study in Ireland. It is not the same as nationality.

Data include enrolments of students of EU and non-EU origin in full-time programmes leading to a higher education qualification within public HEls. Data on enrolments in part-time programmes, access and foundation programmes, and data on Erasmus and occasional students, which are also covered in HEA statistics, are excluded.

Eurostat data indicate that China was the top country of origin of non-EEA students enrolled in full-time higher education in Ireland in each year between 2013 and $2017 .{ }^{40}$ Malaysia represented the second most common country of origin of non-

40 Eurostat, 'Mobile students from abroad enrolled by education level, sex and country of origin', [educ_uoe_mobs02], available at http://appsso.eurostat.ec.europa.eu/nui/show.do?dataset=educ_uoe_mobs02\&lang=en. The Department of Education and Skills reports data on mobile students in higher education gathered by the HEA to Eurostat. 
EEA students in full-time higher education programmes from the 2013-2014 to 2015-2016 academic year. In the 2016-2017 and 2017-2018 academic year, the US represented the second most common country of origin Canada, India and Saudi Arabia have also featured in the top six countries of origin during this period. ${ }^{41}$ Some 55 per cent of non-EEA students enrolled in full-time higher education programmes in Ireland in $\mathbf{2 0 1 7}$ were female. There are some genderbased variations between countries however. In the 2017-2018 academic year, 64 per cent of students from India were male, while 67 per cent of students from the US were female. ${ }^{42}$

Figure 1.8 presents non-EEA student enrolments in full-time higher education courses in public HEls, by field of study in the 2017-2018 academic year. As in previous years, the largest number of non-EEA students $(4,564)$ were enrolled in health and welfare courses, representing 31 per cent of all non-EEA students enrolled in full-time higher education in the 2017-2018 academic year. Business, administration and law and arts and humanities are the top two highest fields of study among both Irish nationals and EU nationals enrolled in third-level programmes in public HEIs in Ireland.

41 Only the ranking is reported as consistent data on the countries of origin of non-EEA nationals attending full-time courses only are not currently available. Consultation with HEA, January 2019.

42 Eurostat, 'Mobile students from abroad enrolled by education level, sex and country of origin', [educ_uoe_mobs02], available at http://appsso.eurostat.ec.europa.eu/nui/show.do?dataset=educ_uoe_mobs02\&lang=en. 


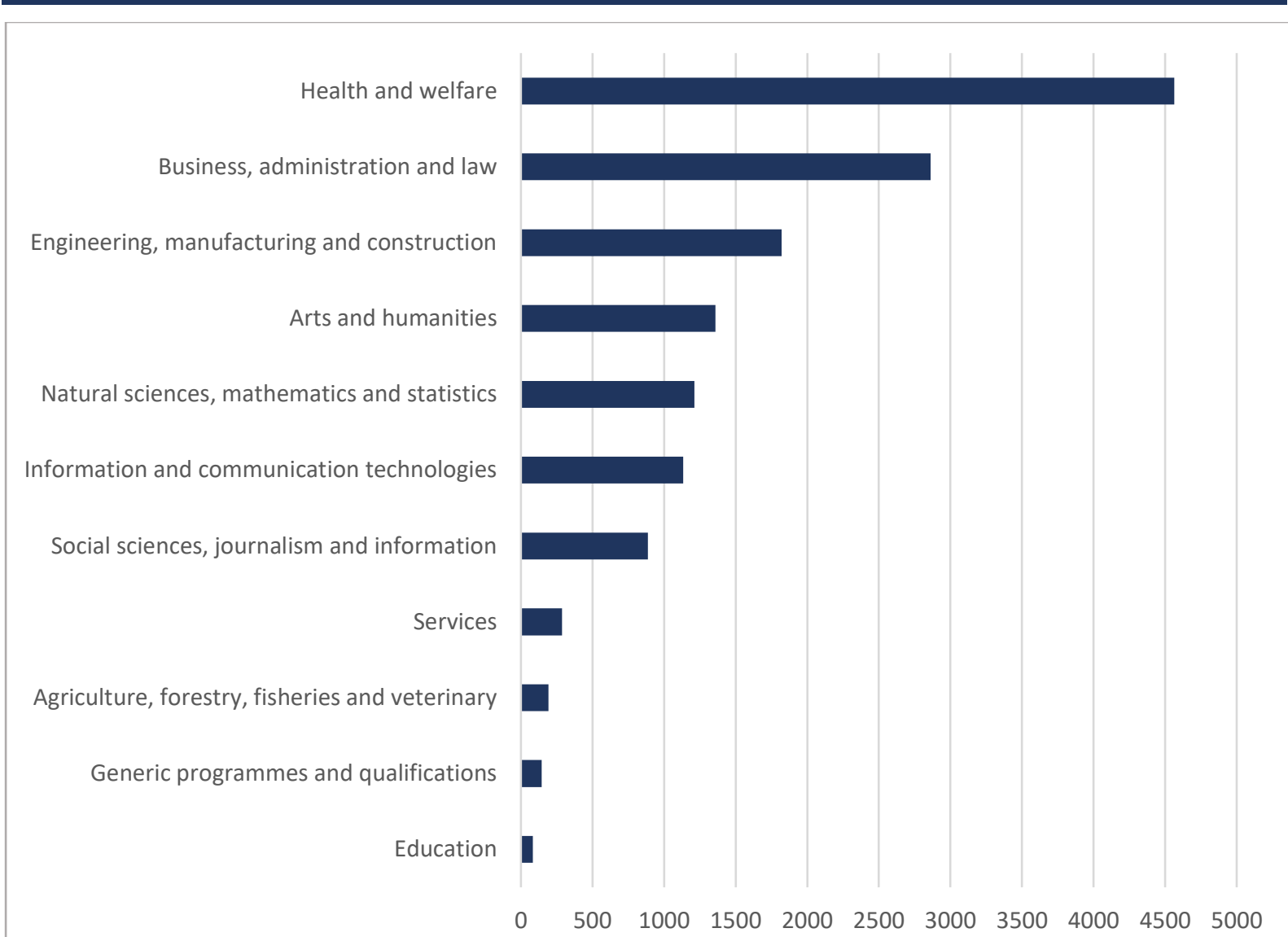

Source: Consultation with HEA, December 2018.

Note: Data on enrolments in part-time programme and access and foundation programmes, and data on occasional students, which are also covered in HEA statistics, are excluded.

The majority of non-EEA students $(7,894)$ were undertaking full-time programmes at honours bachelor's degree level in the 2017-2018 academic year, with 4,019 enrolled in a master's degree, 1,450 undertaking a doctoral degree, and 690 enrolled in an ordinary bachelor's degree. ${ }^{43,44}$ Master's degree programmes saw the largest growth in non-EEA student enrolments since the 2013-2014 academic year, when 1,870 non-EEA students were enrolled in such programmes, representing a 115 per cent increase overall. ${ }^{45}$

The large majority of non-EEA students enrolled in health and welfare programmes $(3,829)$ were at honours bachelor's degree level. Conversely, a slightly larger number $(1,402)$ of those enrolled in business, administration and law were undertaking a master's degree than an honours bachelor's degree $(1,299)$. Of the

43 For a description of the qualifications framework, see: http://www.nfq-qqi.com/.

44 A total of 232 non-EEA students were enrolled at certificate level, a further 101 at higher certificate level, 68 at higher diploma level, 30 at undergraduate diploma level, and 44 at postgraduate diploma level.

45 Consultation with HEA, December 2018. 
non-EEA students enrolled in engineering, manufacturing and construction programmes, 40 per cent (761) were enrolled at honours bachelor's degree level. ${ }^{46}$

In line with the growth in enrolments, the number of non-EEA students who have graduated with a qualification from an Irish HEl has increased since 2013. Figure 4.1 shows that the number of non-EEA graduates increased by 84 per cent between 2013 and 2017. Of the 4,608 non-EEA students who graduated in 2017, 2,413 were graduates of a master's programme, 1,508 were honours bachelor's degree graduates, 404 graduated with a doctoral degree and 281 graduated with an ordinary bachelor's degree. The top three fields in which non-EEA graduates obtained qualifications in 2017 were business, law and administration (1,311 graduates), health and welfare (926 graduates) and engineering, manufacturing and construction (621 graduates). ${ }^{47}$

FIGURE 1.9 NUMBER OF NON-EEA GRADUATES OF PUBLIC HEIS IN IRELAND, 2013-2017

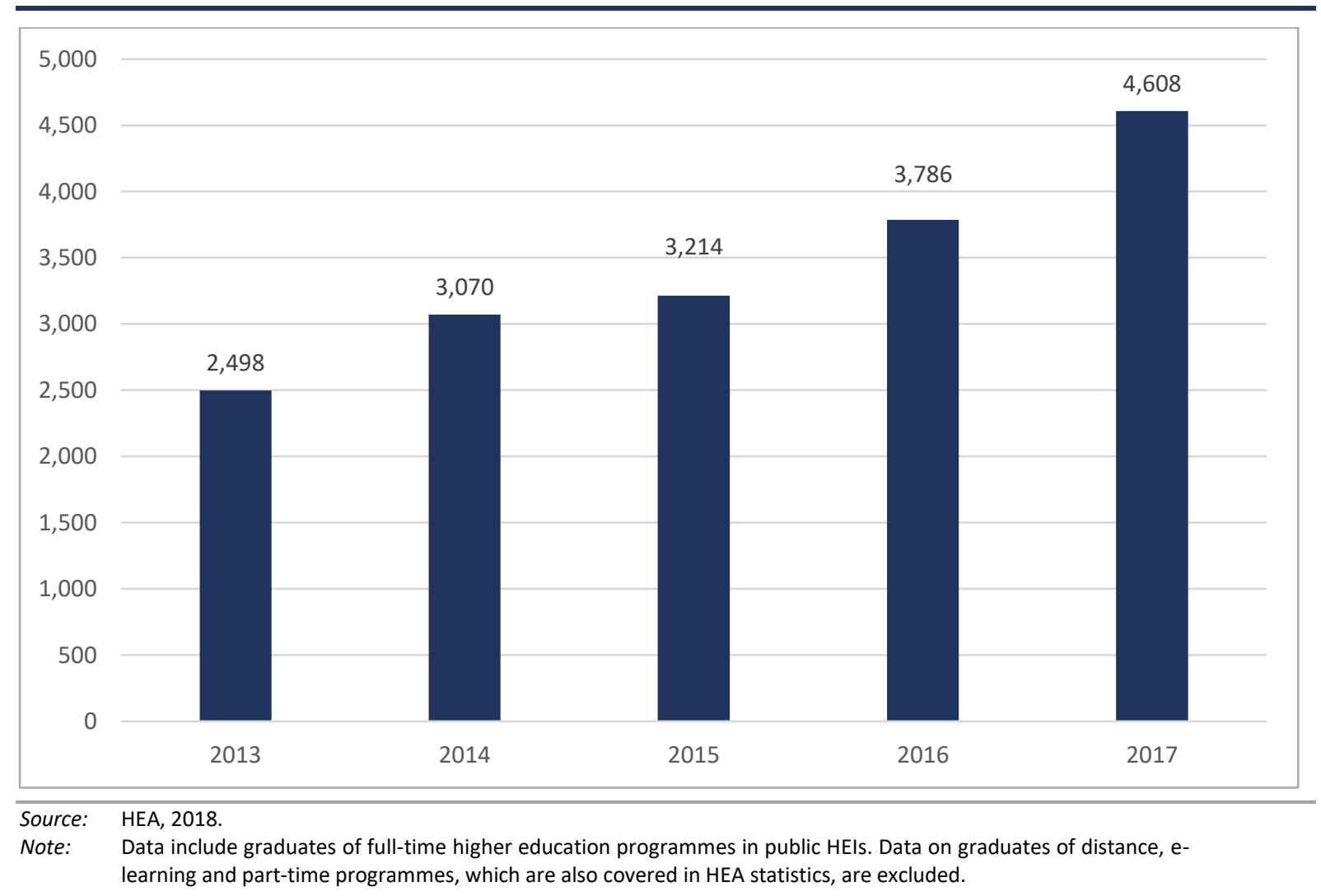

46 Consultation with HEA, December 2018.

47 Consultation with HEA, December 2018. 


\section{CHAPTER 2}

\section{Evolution of national policy and regulatory reforms}

Attracting non-EEA students forms an integral part of national policy on the internationalisation of education. As outlined in Section 1.5, in 2004 the Interdepartmental Working Group had already deemed the development of a comprehensive and coordinated approach as vital to expanding the internationalisation of education in Ireland. The introduction of Ireland's first international education strategy, Investing in global relationships: Ireland's international education strategy 2010-15, and reforms of the non-EEA student immigration framework in 2010, led to a more coherent national policy landscape for international students in Ireland (Finn and O'Connell, 2012).

The period since 2010 has seen the ongoing implementation of objectives contained in Ireland's first strategy and the current strategy, Irish educated, globally connected: An international education strategy for Ireland 2016-2020, was introduced in 2016.

The Higher Education Authority (HEA) noted that international education policy has shifted over time, away from an emphasis on international education primarily as a source of income and towards a stronger focus on quality enhancement. ${ }^{48}$ The first strategy acknowledged that a significant challenge for immigration authorities was to balance the need for competitiveness with appropriate safeguards (Department of Education and Skills, 2010). The current strategy underlines that high quality learner experience and academic quality are factors at the centre of the delivery of international education. It stresses that reforms of the student immigration framework and the regulatory environment for education providers form the basis for further development of the international education sector (Department of Education and Skills, 2016a). Thus, further reforms were made to the non-EEA student regime over the study period to strengthen the immigration system and ensure a strong regulatory framework.

Section 2.1 addresses the national policy framework relating to international higher education, setting out the key policies and objectives in the provision of education to non-EEA students. Section 2.2 outlines recent reforms to the regulatory framework for non-EEA students that have shaped the approach towards the admission of non-EEA nationals for the purpose of higher education in Ireland.

48 Consultation with the HEA, April 2019. 


\subsection{INTERNATIONAL HIGHER EDUCATION POLICY FRAMEWORK}

\subsubsection{International Education Strategies}

\section{International education strategy, 2010-2015}

Ireland's first international education strategy, Investing in global relationships: Ireland's international education strategy 2010-15, was adopted in September 2010. The strategy's High Level Group noted in the strategy's vision that investment in future global relationships is at the core of Ireland's approach to internationalisation. The High Level Group also emphasised the role international students play as advocates of Ireland's education system overseas, as well as the role international education plays in contributing to economic recovery. Other elements of the strategy's vision included the view that internationalisation should be a long-term, sustainable process, one that requires a collaborative approach and places the needs of students at its centre.

The primary objective of the first strategy was that 'Ireland will become internationally recognised and ranked as a world leader in the delivery of highquality international education by providing a unique experience and long-term value to students' (Department of Education and Skills, 2010). The strategy sought to increase the number of full-time international (EEA and non-EEA) students in higher education to 25,5000 and to increase the economic impact of international students (measured through financial contributions such as payment of tuition fees and spending in the economy) to approximately $€ 1.2$ billion. The strategy also aimed to strengthen institutional relationships with priority partner countries so as to include greater collaboration, such as in the area of mobility.

In 2016, the Department of Education and Skills reported that the targets set by the first strategy relating to full-time international student recruitment and the economic impact of international students had been exceeded. By 2016, the economic impact of international students was reported at a minimum of $€ 1.55$ billion per annum. The Department estimated that overall fee income from EEA and non-EEA students in full-time courses in public higher education institutions (HEIs) amounted to $€ 188$ million, with non-EEA students accounting for 94 per cent of the total, at $€ 177$ million. The Department also noted that Ireland's reputation as a destination for international students and the student experience was very strong (Department of Education and Skills, 2016a).

\section{International education strategy 2016-2020}

To build on progress under the first strategy, Ireland's second and current international education strategy, Irish educated, globally connected: An international education strategy for Ireland 2016-2020, was published in 2016. The overall vision of the current strategy is to support Ireland to become 
internationally recognised for the development of global citizens through our internationalised education system and a market leader in attracting international student talent' (Department of Education and Skills, 2016a). A number of high-level goals seek to support the achievement of the strategy's overarching objective. This includes increasing the number of international students, connecting the benefits of internationalisation with enterprises to support national economic ambitions and enhancing international alumni networks to build global connections to support social and economic outcomes for Ireland at home and abroad. The current strategy focuses on five key objectives: providing a high-quality experience for all learners; focusing on academic quality, research and mobility as well as attracting international students; developing a distinctive offer that incorporates intercultural aspects and enterprise engagement; taking an ethical approach to internationalisation; and supporting equality and diversity through internationalisation.

In pursuit of the strategy's vision and high level goals, four strategic priorities are identified:

- a supportive national framework;

- internationally-oriented, globally competitive HEls;

- sustainable growth in the English language training sector;

- succeeding abroad.

Underpinning the strategic priorities are 25 strategic actions for all stakeholders, including government departments, state agencies, education institutions and representative bodies. Included in the actions are further targets to increase fulltime international student enrolments and increase the economic impact of international students to $€ 2.1$ billion by the 2019-2020 academic year.

The current strategy states that supportive and cohesive government policy is crucial to its success. The strategy was therefore developed with reference to a number of key national policy developments, in which the international education sector has an important role to play. The national skills strategy, Ireland's national skills strategy 2025, which sets out targets for skills development and delivering long-term sustainable growth, views the current strategy as a means of attracting global talent to Irish HEls and fulfilling the objective of increasing the supply of skills to the Irish labour market (Department of Education and Skills, 2016b). The foreign languages strategy, Languages connect - Ireland's strategy for foreign languages in education 2017-2026, notes that international students have the potential to be a significant resource in meeting the language needs of employers in Ireland, while also providing intercultural awareness expertise and an opportunity for employees to interact through another language in the workplace. A particular measure identified in the foreign languages strategy is the promotion by Enterprise Ireland, 
IDA Ireland, the Department of Foreign Affairs and Trade, and the Department of Education and Skills, of the Third Level Graduate Programme (TLGP) among international students, particularly those with native competency in languages required by enterprise (Department of Education and Skills, 2017). In Ireland's most recent trade and investment strategy, Ireland connected: Trading and investing in a dynamic world, the value of the international education sector, and its ability to create links between Ireland and partners at individual, institutional and country level that will bring further engagement and economic activity in the future, is emphasised (Department of Business, Enterprise and Innovation and Department of Foreign Affairs and Trade, 2017). Attracting international talent is also one of the pillars of Future jobs Ireland 2019, which outlines the government's longer-term ambitions for the economy (Government of Ireland, 2019).

The current strategy also makes reference to the National strategy for higher education to 2030, which was launched in 2011 to set out a long-term vision for the higher education system in Ireland. That strategy recommended that a performance evaluation framework for the governance of higher education be put in place (Department of Education and Skills, 2011). The HEA, which is responsible for the strategic development of the higher education sector in Ireland, subsequently launched the first Higher Education System Performance Framework in 2013, which established national priorities and objectives for the higher education system. HEls are responsible for developing individual performance compacts, or formal agreements, set within the context of national objectives, through a process of strategic dialogue with the HEA (HEA, 2013). The current international education strategy states that the HEA has a central role to play in the internationalisation of higher education, in partnership with government departments and state agencies, and the strategic dialogue provides a strong mechanism for supporting a holistic approach to internationalisation (Department of Education and Skills, 2016a).

The current international education strategy emphasises that implementation of its actions involves all stakeholders on a partnership basis. Stakeholders responsible for the implementation of each strategic action are set out in the strategy. The strategy states that progress will be monitored through the publication of an annual report on internationalisation. A formal review was set to take place in mid-2018. As with the first strategy, the High Level Group on International Education is responsible for monitoring overall implementation of the current strategy. This is a steering group that advises and supports the internationalisation of higher education in Ireland. Members include the representatives from the following government departments: Department of Education and Skills, Department of Justice and Equality, Department of Foreign Affairs and Trade, Department of Business, Enterprise and Innovation and Department of Transport, Tourism and Sport. The Group also includes 
representatives from the HEA, Enterprise Ireland, Quality and Qualifications Ireland (QQI), Irish Council for International Students (ICOS), and HEI representative bodies, including the Irish Universities Association (IUA) and Technological Higher Education Association (THEA), among others. ${ }^{49,50}$

\subsubsection{HEl internationalisation strategies}

The second strategy emphasises that HEls are the primary drivers of the internationalisation of higher education in Ireland (Department of Education and Skills, 2016a). Higher education in Ireland is provided by over $40 \mathrm{HEls}$ (Clarke et al., 2018), including 23 public HEls and several private colleges. Public HEls include seven universities, one technological university, 11 institutes of technology and four colleges of education. ${ }^{51} \mathrm{HEls}$ are required to meet a number of conditions in order to offer programmes to international students (see Section 2.2).

HEls have developed internationalisation strategies setting out institutional objectives and targets (Clarke et al., 2018). When the internationalisation of education was first addressed at a national level in 2003, the success of HEls in attracting international students to Ireland was highlighted (Department of Education and Science, 2004). National internationalisation strategies have influenced HEls to further their internationalisation objectives (Clarke et al., 2018).

Ireland's first strategy stated that institutions should develop comprehensive internationalisation strategies. Such strategies would have regard to national policy and priorities and would set out visions, objectives and targets, as well as implementation structures and resources to be applied. Areas for consideration in internationalisation strategies, as outlined in the first strategy, include international student targets, capacity development, transnational education, internationalised curriculum, integration and student supports, international partnership development and improving global competitiveness (Department of Education and Skills, 2010).

A report commissioned by the HEA in 2018 to examine the development of internationalisation in HEls found that significant efforts have been made by HEls in the area of internationalisation (Clarke et al., 2018). Internationalisation featured in the strategic plans of HEls and was also referred to in documents such as business plans and mission statements. In most HEls, internationalisation was

49 ICOS is a voluntary organisation comprised of more than 30 member institutions, including all universities, some institutes of technology and private colleges, as well as the Union of Students in Ireland and other organisations. ICOS promotes the rights and welfare of international students and provides support to HEls in relation to international students.

50 Department of Education and Skills, 'High Level Group on International Education', available at https://www.education.ie/en/The-Department/Regulation-of-Lobbying-Act-2015/Groups-Committees-exemptedunder-the-Transparency-Code/High-Level-Group-on-International-Education.html.

51 Consultation with HEA, December 2018. 
observed as being driven primarily by senior management teams, with input provided by a range of HEl stakeholders, including academic councils, schools within HEls, international offices and faculty.

HEls monitor the progress of their own internationalisation strategies in conjunction with the HEA and the Higher Education System Performance Framework (Department of Education and Skills, 2016a).

In September 2018, Ireland's seven universities signed a charter led by the Irish Universities Association. Ireland's future talent: A charter for Irish universities sets out commitments by universities, in partnership with the government and other stakeholders, to meet national targets for the higher education system. Commitments include building on the international reach of universities by increasing the number of international students. In addition, the charter commits to ensuring broader benefits of internationalisation, including outward student mobility and exchange, internationalisation of the curriculum and nurturing international alumni. The charter acknowledges the need to address key barriers to progress, such as accommodation, pressure on student services and immigration policy (Irish Universities Association, 2018).

\subsubsection{Challenges}

\section{Funding and capacity of the higher education sector}

HEls observed in the 2018 report that internationalisation efforts were constrained by a lack of resources. The capacity of HEls was also highlighted by stakeholders consulted for this study as a challenge to attracting international students. ${ }^{52}$ The HEA noted that achieving the aims of the current strategy in the face of funding gaps is a challenge (HEA, 2017b). The Irish Universities Association observed that such funding gaps are putting pressure on student services such as careers, health and counselling. ${ }^{53}$ The Irish Universities Association charter highlights the need for a sustained programme of investment to build capacity for future growth in student numbers. The charter also observes that an under-funded higher education system may become unattractive for international students (Irish Universities Association, 2018).

The HEA note that while there the past decade has seen significant growth in the number of students enrolling in higher education, state funding allocations to HEls have not increased over the same period (HEA, 2017b). Pritchard and Slowey (2017) note that the economic crash had a dramatic impact on higher education in Ireland, whereby core state expenditure in education declined steeply from 2007 onwards at a time when student numbers were increasing. Clarke et al. (2018)

Consultation with HEI, November 2018.

53 Consultation with IUA, December 2018 
report that state grants to the higher education sector declined by 38 per cent in the same period. The HEA has reported that overall funding per student declined by 20 per cent between $2008(€ 12,000)$ and $2016(€ 10,000)$ (HEA, 2017b).

The Expert Group on Future Funding for Higher Education, which was established in 2014 to examine future funding policy for higher education, produced a report in 2016 that recommended an increase in investment in higher education over the subsequent 15 years and proposed a number of funding options to the government (Expert Group on Future Funding for Higher Education, 2016). A decision on future funding of the higher education sector is yet to be made (Murray, 2018). The Oireachtas noted that a reformed funding model for the higher education sector is necessary to ensure sufficient supports are in place to attract and retain international students (Oireachtas Library \& Research Service, 2017).

In an analysis of 34 higher education systems, in its 2017 report, the European University Association's Public Funding Observatory has classified Ireland and two other countries (Croatia and Iceland) as a 'system in danger' in light of funding cuts made in the context of increased student numbers (Bennetot Pruvot et al., 2017). Ireland was similarly classified by the Observatory in its 2018 report as a system 'in danger', alongside Serbia, despite continue economic growth and one of the highest average GDP growth rates in Europe. While the 2018 report observed 'improving patterns' in Ireland on the basis of a 4.8 per cent increase in investment in the sector between 2016 and 2017, the report found that this investment is insufficient to redress the financial situation and meet funding requirements identified by the Expert Group (Bennetot Pruvot et al., 2019).

Due to a lack of national funding, HEls have sought to diversify income sources and generate revenue from non-governmental sources (HEA, 2017a; Pritchard and Slowey, 2017). The current strategy states that international education has become an increasingly significant source of funding for HEls in Ireland. However, while the strategy highlights the importance of maintaining and enhancing international education as a funding source, it states that there is a need for further resources and sustainable investment in international education, in order to achieve the targets set out in the strategy (Department of Education and Skills, 2016a).

\section{Brexit}

A 'whole-of-island' approach to internationalisation and north-south cooperation in promoting the island of Ireland as a destination for international students is given particular attention in the current strategy. Such engagement is also seen as important following the result of the UK's 2016 referendum on the future of the UK in the EU and the invocation of Article 50 of the Treaty on the European Union, 
which followed in March 2017. The current international education strategy therefore states that developments and any opportunities or threats emerging as a result of Brexit will be kept under review and appropriate responses taken (Department of Education and Skills, 2016a).

In 2017, the Oireachtas Joint Committee on Education and Skills discussed the impact of Brexit on higher education in Ireland, including possible increases in international students applying for courses in Ireland. ${ }^{54}$ While Brexit has been highlighted as an opportunity to attract international students to HEls in Ireland who may have otherwise studied in the UK, funding and capacity constraints mean that a potential increase in international students has been identified as a risk for the higher education sector (Royal Irish Academy Brexit Taskforce, 2017, Griffin, 2018a).

It has also been argued that Brexit could have a negative effect on student flows from Northern Ireland to Ireland (O'Brien, 2019; O'Brien, 2018b). ${ }^{55}$ A report published by the HEA and Northern Ireland's Department for the Economy observed that students from Northern Ireland who study in Ireland in the future may be required to pay fees applicable to non-EEA nationals, which may have the effect of reducing the flow of students from Northern Ireland to Ireland, following Brexit (HEA and Department for the Economy, 2018). The Department of Education and Skills is examining the need for legislation to ensure all students on the island of Ireland can continue to be charged on the same basis (O'Brien, 2019). To provide clarity to students, the Department of Education and Skills announced in January 2019 that prospective UK students wishing to study in Ireland would continue to be eligible for the Department of Education's Free Fees and Student Grant Scheme, which is available to all EEA nationals, for the 2019-2020 academic year, irrespective of the outcome of Brexit negotiations. ${ }^{56}$

\subsection{NON-EEA STUDENT EDUCATION AND IMMIGRATION REGULATORY REFORM}

As mentioned in Section 1.5, significant reforms of the non-EEA student immigration framework were introduced in 2010 as part of the overall reform of the national policy framework for international students (INIS, 2010). These

54 Houses of the Oireachtas, 'Joint Committee on Education and Skills debate', 21 March 2017, available at https://www.oireachtas.ie/en/debates/debate/joint_committee_on_education_and_skills/2017-03-21/3/.

55 Ibid.

56 The position will be reviewed in advance of the 2020-2021 academic year. See: Department of Education and Skills, 'Ministers McHugh and Mitchell O'Connor announce decision to continue supports for prospective higher education students wishing to study in the UK and UK nationals wishing to take up studies in Ireland for the 2019/2020 academic year', press release, 11 January 2019, available at https://www.education.ie/en/Press-Events/Press-Releases/2019press-releases/PR19-01-11a.html; Department of Education and Skills, 'Ministers McHugh and Mitchell O'Connor announce the opening of the Student Grant Scheme for 2019', press release, 15 April 2019, available at https://www.education.ie/en/Press-Events/Press-Releases/2019-press-releases/PR19-04-25.html. 
reforms, alongside the introduction of Ireland's first international education strategy discussed in Section 2.1, led to a more coherent national policy landscape for international students in Ireland (Finn and O'Connell, 2012).

The non-EEA student education and immigration framework has undergone further regulatory reforms since 2011. Many of the changes were intended to strengthen the immigration system in response to suspected misuse of the student migration route to access the labour market and to ensure a strong regulatory framework for developing the international education sector. In particular, the period between 2014 and 2015 saw the introduction of a number of reforms to the student immigration regime.

\subsubsection{Quality assurance: The International Education Mark (IEM)}

Included in the first international education strategy's third strategic action, 'Quality will be at the heart of Ireland's international education offering', was a commitment to introduce the International Education Mark (IEM) and a code of practice, which had been proposed in 2004 to ensure quality assurance standards in the international education sector (Department of Education and Skills, 2010). The first strategy also stated that immigration rules would be aligned with the IEM, so that international students would not receive permission to remain in Ireland for the purposes of study at an institution that does not hold the IEM (Department of Education and Skills, 2010). In 2012, the Qualifications and Quality Assurance (Education and Training) Act 2012 provided the statutory basis for the development of the IEM and code of practice by QQI. ${ }^{57}$

In 2015, QQI published the Code of practice for provision of programmes of education and training to international learners, which is a set of threshold requirements for education providers relating to the quality of supports and services available to international students. Criteria that must be met relate to protection of learners, marketing, recruitment and admissions, fees, refunds and subsistence, and pastoral and academic supports and services (QQI, 2015). When implemented, QQI will assess education providers' compliance with the code of practice when determining applications to use the IEM (QQI, 2014; Oireachtas Library \& Research Service, 2018).

In 2013, QQI published a Green Paper on the IEM setting out issues for consultation ahead of its introduction (QQI, 2013). QQI's White Paper followed a year later, setting out the proposed policy and criteria for education providers seeking authorisation to use the IEM (QQI, 2014). Criteria for awarding the IEM to an education institution include: quality assurance arrangements being in place;

57 Qualifications and Quality Assurance (Education and Training) Act 2012, as amended, ss 60-61. 
arrangements for access, transfer and progression of learners being in place; and programmes leading to awards recognised within the National Framework of Qualifications (NFQ).

Applications for the IEM were initially due to be taken from January 2015 (Department of Education and Skills and Department of Justice and Equality, 2014). However, the IEM's introduction was delayed pending legislation that provides for its operation. ${ }^{58}$ Ireland's current strategy makes a commitment to bringing forward legislation to introduce the IEM by 2018 as part of a strategic action to ensure a robust regulatory environment for international education provision (Department of Education and Skills, 2016a). In May 2017, the Minister for Education and Skills introduced the draft outline of legislation giving powers to QQI to award the IEM. In July 2018, the Qualifications and Quality Assurance (Education and Training) (Amendment) Bill 2018 was published. The Bill amends the Qualifications and Quality Assurance (Education and Training) Act 2012 to provide for legislative reforms to strengthen QQI in its regulatory role and to allow for the introduction of the IEM. ${ }^{59}$ The Bill was initiated in the Oireachtas on 1 August 2018 and, as of May 2019, is before the Seanad. ${ }^{60}$

\subsubsection{Policy statement on regulatory reform, 2014}

From the beginning of 2014, a number of private education colleges closed, impacting over 3,000 non-EEA students enrolled in the colleges (Joyce and Whelan, 2015; Department of Education and Skills and Department of Justice and Equality, 2014, 2015, Irish Times, 2014). Following the closures, the Minister for Education and Skills and the Minister for Justice and Equality established a Task Force on Students Affected by the Closure of Private Colleges in May 2014. The Task Force submitted its report to the two ministers in July 2014. The report noted that while significant efforts had been made to ensure alignment between quality assurance and immigration policies, through both the first strategy and student immigration reforms introduced in 2010, a minority of education providers had continued to engage in unsustainable practices. Such practices included a lack of sufficient learner protection arrangements, unsustainably low fees that were inadequate to provide for delivery of high-quality programmes and the offering of programmes that were not Irish-accredited or quality assured. The Task Force also observed that a cohort of students in the colleges were in Ireland to access the labour market or for other reasons not related to education. The Task Force therefore found that a

58 A particular difficulty preventing the introduction of the IEM relates to the fact that QQI does not have express legal power to recognise awards. As one of the requirements for education providers applying for the IEM is that programmes must be recognised within the NFQ, the IEM could not be introduced until legislative amendments were made to facilitate its full operation. See: Oireachtas Library \& Research Service (2018).

59 Ibid

60 Houses of the Oireachtas, 'Qualifications and Quality Assurance (Education and Training) (Amendment) Bill 2018', available at https://www.oireachtas.ie/en/bills/bill/2018/95/. 
stronger regulatory environment for the provision of international education was needed (Task Force on Students Affected by Private College Closures, 2014).

Following the publication of the Task Force's report, the Department of Education and Skills and the Department of Justice and Equality issued the policy statement, Regulatory reform of the international education sector and the student immigration regime, in September 2014. The then Minister for Education and Skills, Jan O'Sullivan, stated at the time that the reforms were crucial to ensuring only providers that can offer the highest standards can attract international students to Ireland. ${ }^{61}$

The statement set out three pillars of reforms, with effect from 1 January 2015:

- A more restrictive list of eligible programmes for student immigration purposes;

- An enhanced inspection and compliance regime;

- Revised terms of the student work concession.

The statement also committed to publishing guidelines on other regulatory issues, such as financial requirements for students coming to Ireland and separate accounts for student funds pending visa decisions (Department of Education and Skills and Department of Justice and Equality, 2014). ${ }^{62}$

\section{Interim List of Eligible Programmes (ILEP)}

As the IEM was still under development, the Department of Education and Skills and Department of Justice and Equality announced the introduction of the Interim List of Eligible Programmes (ILEP), which replaced the former Internationalisation Register..$^{63}$ This is to be used until the IEM, and a more permanent system for programme eligibility, is put in place (Department of Education and Skills and Department of Justice and Equality, 2014). The ILEP was introduced as a mechanism to better regulate the immigration of non-EEA nationals for study purposes, by identifying higher education and English language programmes for which non-EEA students could be granted immigration permission. ${ }^{64}$ Eligibility for inclusion on the ILEP initially took into account the following:

61 Department of Education and Skills, 'Ministers O'Sullivan and Fitzgerald launch major reform of student immigration and the international education sector', press release, 2 September 2014, available at https://www.education.ie/en/Press-Events/Press-Releases/2014-Press-Releases/PR14-09-02.html.

62 Guidance on financial requirements for immigration registration and visa applications are provided on the INIS website. See Sections 2.2.4 and 3.2.1 of this report.

63 The Internationalisation Register was a list of programmes established in 2004 to regulate access for non-EEA students to employment during studies in line with the Student Work Concession. Students enrolled in the programmes listed on the Register could access employment during studies subject to certain conditions. However, the Internationalisation Register also came to be viewed as a reference point for INIS in considering non-EEA study visa and residence permission applications (see Finn and O'Connell, 2012).

64 INIS, 'Interim List of Eligible Programmes', available at http://www.inis.gov.ie/en/INIS/Pages/Interim\%20List\%20of\%20Eligible\%20Programmes\%20-\%20ILEP. 
- programme accreditation (generally only programmes accredited or recognised by Irish awarding bodies in the English language and higher education sector would be eligible);

- immigration compliance;

- a track record as a quality educational provider to Irish or EU students; and

- authorisation to use the IEM, once introduced (Department of Education and Skills and Department of Justice and Equality, 2014).

\section{Enhanced inspection and compliance regime}

The 2014 reforms included the introduction of an enhanced inspection regime, which partly comprised a greater inspection function for the Irish Naturalisation and Immigration Service (INIS) and the Garda National Immigration Bureau (GNIB) to review attendance management systems and student immigration permission compliance. This regime is linked to wider oversight in relation to tax compliance, abuse of the student work concession and social protection issues where necessary. QQI continues to monitor private providers, for which it makes higher education awards and monitoring will also be put in place as part of the IEM framework. A compliance working group was tasked with reviewing the operation of providers and student work concession (Department of Education and Skills and Department of Justice and Equality, 2014).

\section{Student work concession}

Access to the labour market for international students during their studies was introduced in 2001, partly as an incentive to attract international students to Ireland (Finn and O'Connell, 2012). Both degree programme and language and non-degree programme non-EEA students on a Stamp 2 permission are permitted to work for up to 20 hours per week during the academic term and up to 40 hours per week on a full-time basis during college holiday periods without needing to hold an employment permit (INIS, 2011a; INIS, 2011b).

When first introduced, college holiday periods were not defined and variations in term time and holiday periods between colleges left the concession difficult to monitor (Department of Education and Skills and Department of Justice and Equality, 2014; Sheridan and Whelan, 2016). As a result, the reforms standardised operation of the work concession from 1 January 2015, limiting college holiday periods in which non-EEA students are permitted to work to the period between 15 December to 15 January and the months of May, June, July and August.

\subsubsection{Policy statement on regulatory reform, 2015}

On 25 May 2015, the Minister of Education and Skills and the Minister for Justice and Equality approved a series of further reforms to build on those set out in the 2014 Policy Statement. They also provided additional standards and safeguards in 
the provision of international education. ${ }^{65}$ The reforms introduced in 2015 related primarily to the introduction of the ILEP, while additional requirements for English language students were also introduced. The 2015 statement also stated that the work concession reforms, which were introduced from 1 January 2015 in line with the 2014 statement, would be kept under review (Department of Education and Skills and Department of Justice and Equality, 2015).

\section{Phasing-in of ILEP}

The 2014 Policy Statement stated that the ILEP would be published on 1 January 2015. However, its introduction was postponed due to a legal challenge by two private colleges regarding the impact of the proposed reform on the English language sector (Department of Education and Skills and Department of Justice and Equality, 2015). The ILEP was subsequently introduced on a phased basis from 1 June 2015. The first phase included removal of all further education programmes (below NFQ Level 6) and overseas accredited vocational and training programmes from the list of programmes that had been included on the Internationalisation Register. The second phase addressed the inclusion of English language programmes on the list. The ILEP was published in January 2016 (Sheridan and Whelan, 2016).

The 2015 Policy Statement set out a number of additional requirements to be met by providers seeking inclusion on the ILEP, including full disclosure of ownership, learner protection arrangements, declarations regarding student capacity and a separate account facility to safeguard student payments pending visa decisions (Department of Education and Skills and Department of Justice and Equality, 2015).

The Department of Education and Skills and the Department of Justice and Equality are jointly responsible for managing the ILEP. The inclusion of courses is decided by the Department of Justice and Equality, having consulted with the Department of Education and Skills (Department of Education and Skills and Department of Justice and Equality, 2015). A number of criteria must be met for an institution to be included on the ILEP, which are subject to ongoing review by the Department of Justice and Equality and Department of Education and Skills (INIS, 2018a). The criteria were most recently updated with effect from 14 September $2018 .{ }^{66}$ Included in the criteria are:

- a record of service delivery and compliance with conditions relating to ownership, operation and quality assurance;

65 INIS, 'Ministers O'Sullivan and Fitzgerald announce Government approval of reforms to the student immigration system for international education', press release, 25 May 2016, available at https://merrionstreet.ie/en/NewsRoom/Releases/Ministers_0\%E2\%80\%99Sullivan_and_Fitzgerald_announce_Government_approval_of_reforms_to_th e_student_immigration_system_for_international_education.html.

66 INIS, 'Interim List of Eligible Programmes (ILEP)', available at http://www.inis.gov.ie/en/INIS/Pages/Interim\%20List\%20of\%20Eligible\%20Programmes\%20-\%20ILEP. 
- a track record of education;

- programme accreditation.

HEls applying to be listed on the ILEP are also required to:

- provide assistance to students on immigration-related issues;

- provide information to students, such as on awards granted, health insurance and fees;

- provide pastoral care and advice to students in relation to matters such as finding accommodation, opening a bank account and accessing medical services;

- have emergency procedures in place, documented and publicly available;

- put in place arrangements for the protection of students in the event that a programme ceases prematurely (this can take the form of arrangements for a student to complete the programme with another provider(s), or have their unspent fees and related costs reimbursed); and

- provide for a separate account facility to safeguard student advance payments until the student's visa application is determined (in cases where a visa application is refused, the funds, less any pre-indicated handling charge, must be returned to the student within a specified time) (INIS, 2018a).

Ongoing monitoring of institutions listed on the ILEP takes place to ensure that institutions comply with immigration rules. Institutions may be removed from the list if they are found to be in breach of ILEP requirements or have engaged in immigration abuse. ${ }^{67}$

The ILEP has since been updated every four months and will continue to be updated until the IEM is in place (Sheridan, 2017; Sheridan, 2018). Over 6,950 higher education and English language programmes are currently listed on the ILEP and are offered by a mix of over 130 state and private providers. ${ }^{68}$

\subsubsection{Further reforms and policy developments}

\section{Student work concession}

Following a further review of the student work concession's terms, the summer college holiday period was redefined to cover June, July, August and September, with effect from 1 September $2016 .{ }^{69}$

67 Ibid.

68 Consultation with INIS, February 2019.

69 INIS, 'Note to employers: Changes to the employment entitlements of non-EEA students holding Immigration Stamp 2 - with effect from 1 September 2016', available at http://www.inis.gov.ie/en/INIS/Pages/Changes\%20to\%20the\%20Employment\%20entitlements\%20of\%20NonEEA\%20Students\%20holding\%20Immigration\%20Stamp\%202\%20\%E2\%80\%93\%20with\%20 effect\%20from\%201\%20Se ptember\%202016. 


\section{Third Level Graduate Programme (TLGP)}

Permission to remain following studies was first granted to non-EEA international graduates of degree programmes in 2007 with the introduction of the TLGP, mentioned earlier in Section 2.1.1 (see also Section 4.1).

Up to 2016, graduates availing of the TLGP held a Stamp 2 permission like other non-EEA international students. However, in order to provide clarity and ensure employers can distinguish graduates from students on a Stamp 2 permission (who are subject to work concession restrictions), since February 2016 graduates qualifying for the TLGP are granted a new Stamp 1G immigration stamp (Sheridan, 2017). Permission to remain under the programme was initially granted to graduates with a qualification at NFQ Level 7 and above for a period of up to six months (Finn and O'Connell, 2012). To enhance Ireland's attractiveness as a destination for non-EEA students, in 2011 permission under the TLGP was extended to 12 months for graduates at NFQ Level 8 and above (Finn and O'Connell, 2012).

The current international education strategy (2016-2020) includes a commitment to amend the TLGP by the end of 2016 in order to further incentivise high performing students to come to Ireland and remain after their studies in order to help meet Ireland's skills and language needs (Department of Education and Skills, 2016a). The TLGP was subsequently reformed in May 2017 to allow graduates at NFQ Level 9 and above to remain in Ireland for a period of up to two years, subject to an overall eight-year limit on residence in Ireland. The HEA, Enterprise Ireland and Crosscare observed that the extension of the TLGP for NFQ Level 9 graduates is positive, providing graduates with a longer period of time to seek employment opportunities. ${ }^{70}$ ICOS and Enterprise Ireland also observed that the extension for NFQ Level 9 graduates is attractive for non-EEA students. ${ }^{71}$

Under the reforms introduced in 2017, non-EEA students enrolled after 31 May 2017 in a programme leading to an award at NFQ Level 7 are no longer permitted to avail of the TLGP. Transitional arrangements allow non-EEA students enrolled on or before 31 May 2017 on a programme leading to an award at NFQ Level 7 to continue to avail of a six-month residence permission. These transitional arrangements will cease to apply after 31 December 2019 (INIS, 2017).

\section{Revised finance requirements}

In order to be granted permission to enter and reside in Ireland for the purposes of study, non-EEA students must be able to demonstrate access to sufficient funds

70 Interview with Enterprise Ireland, November 2018; Interview with HEA, November 2018; Interview with Crosscare, November 2018.

71 Interview with ICOS, October 2018; Interview with Enterprise Ireland, November 2018. 
to support themselves while living and studying in Ireland (see Section 3.2.1). Students coming from countries that are visa-required for entry to Ireland must provide evidence of access to $€ 7,000$ at the time of their visa application. In order to be granted a residence permission, non-EEA students must also show evidence of access to $€ 3,000$ at the time of registration. Revised requirements and guidance regarding evidence of finances for non-EEA students were introduced from 1 September 2016. ${ }^{72}$ The requirements provided that visa-required students are no longer obliged to present evidence of sufficient funds on registration for a residence permission, as it was considered appropriate checks on finance are already undertaken as part of the visa application process.

\section{Regularisation scheme for former international students}

$\mathrm{MRCl}$ observed that a significant section of the current population of irregular migrants in Ireland fell into irregularity following the immigration reforms that were introduced from 2011 onwards (Arnold et al., 2017). This issue as it concerns non-EEA students was partly addressed between October 2018 and January 2019, when the Department of Justice and Equality put in place a new regularisation scheme for former international students. ${ }^{73,74}$ The short-term scheme was available for those non-EEA students who held a valid student residence permission during the period between 1 January 2005 and 31 December 2010 and who had not acquired an alternative immigration permission (apart from studenttype permissions, such as Stamp 1G, Stamp 2, temporary Stamp 1, Stamp 2A, Stamp $1 A$ ) in the intervening period. ${ }^{75,76,77}$ Successful applicants are granted a Stamp 4S permission, which grants permission to live and work for two years in the State without the need for an employment permit. At the end of the two years, applicants will be granted a Stamp 4 permission for one year, which is renewable,

72 INIS, 'Notice regarding evidence of finances for all non EEA students', available at http://www.inis.gov.ie/en/INIS/Pages/Notice\%20Regarding\%20Evidence\%20of\%20Finances\%20for\%20all\%20Non\%20 EEA\%20Students.

73 Department of Justice and Equality, 'Minister Flanagan announces special scheme allowing certain non-EEA nationals to apply for permission to remain in the State', 15 October 2018, available at http://justice.ie/en/JELR/Pages/PR18000323.

74 The Scheme follows the introduction of a similar scheme in 2012, otherwise known as the Student Probationary Extension. See: Finn and O'Connell (2012).

75 INIS, 'Special scheme for non-EEA nationals who held a student permission in the State during the period 1 January 2005 to 31 December 2010', http://www.inis.gov.ie/en/INIS/Pages/special-scheme-for-non-eea-nationals-who-held-astudent-permission-in-the-state-during-the-period-1-january-2005-to-31-december-2010.

$76 \mathrm{MRCl}$, 'Student scheme 2018', available at https://www.mrci.ie/2018scheme/.

77 The introduction of the new scheme follows the Supreme Court judgment in Luximon $v$ Minister for Justice and Balchand v Minister for Justice [2018] IESC 24 in April 2018, which involved two non-EU nationals who had entered Ireland in 2006 and resided in Ireland on the basis of a Stamp 2 student permission up to 2011. Both individuals subsequently applied to change their residence permission to a Stamp 4 permission in order to regularise their residence in the State; however, their applications were unsuccessful and they were ordered to leave the State. The Court held that the Article 8 ECHR right to private and family life must be taken into account by the Minister of Justice when deciding an application for change of immigration status. 
if they can provide evidence that they have complied with the terms of the Stamp $4 \mathrm{~S}$ permission. ${ }^{78}$ 


\section{CHAPTER 3}

\section{Attracting international students}

Ireland's first international education strategy had, as part of its ten strategic actions, a commitment to strengthen national promotion and marketing (Department of Education and Skills, 2010). Building on this commitment, the current strategy notes that the recruitment of international students is a key component of the internationalisation strategy for the higher education sector. One of the four strategic priorities of the strategy is 'succeeding abroad', which commits to building partnerships in overseas markets, exploring additional highpotential market opportunities, increasing the visibility of the Education in Ireland brand and strengthening engagement with alumni to support the recruitment of international students (Department of Education and Skills, 2016a).

As stated in Chapter 1, the harmonisation of EU rules relating to the admission of non-EEA students is a key part of increasing the attractiveness of the EU as a destination for higher education. While Ireland has not opted into the EU Directives pertaining to non-EEA students, Ireland's first international education strategy (2010-2015) recognised that competitive immigration and labour market access policies are important in facilitating internationalisation (Department of Education and Skills, 2010).

This chapter examines measures in place to attract and facilitate the admission of non-EEA students to Ireland. Section 3.1 addresses measures in place to encourage third-country nationals to study in Ireland. Section 3.2 examines the immigration conditions applicable to non-EEA students in Ireland.

\subsection{PROMOTING IRELAND AS A DESTINATION FOR NON-EEA STUDENTS}

Ireland's current international education strategy notes that global competition in the provision of international education is growing, notably in the areas of fees, immigration and residency conditions, and opportunities for employment (Department of Education and Skills, 2016a). Australia, Canada, the UK and the US are among Ireland's largest competitors in providing for international education. ${ }^{79}$ In addition, the current strategy cautions that the dominance of English-speaking countries in the international education sector is increasingly being challenged by non-native English speaking countries providing programmes delivered through English. The provision of programmes taught through English has significantly increased in recent years (EMN, forthcoming), which may affect Ireland's competitive advantage (Griffin, 2018b). The 2012 European Migration Network

79 Interview with Enterprise Ireland, November 2018. 
(EMN) study on international students reported that 75 per cent of international study programmes in the Netherlands were taught entirely through English (EMN, 2012).

The fact that Ireland is an English-speaking country is however only one of many key factors that attract international students to Ireland (Clarke et al., 2018; Southern Cross Consulting, 2018). Clarke et al. (2018) found that, while Ireland was often not initially considered as a destination for studying abroad by many students, the final decision to study in Ireland was informed by institutional reputation, specific courses available, research quality, location, cost of living, earning potential, social life and the institutional scholarships or bursaries available. The research also found that some students were attracted to Ireland due to partnerships between Irish universities and universities in their home countries. The Higher Education Authority (HEA) and Enterprise Ireland also observed that the overall student experience is an important factor in attracting students to Ireland.$^{80}$ Finn and Darmody (2017) highlighted that satisfaction levels among international students in Ireland were mainly influenced by the students' experience of the education institution at which they are studying, including their social experience.

The current strategy notes that higher education institution (HEI) rankings are important in students' perception of HEls in Ireland (Department of Education and Skills, 2016a). High rankings of universities in relation to expertise in specific fields of education are also relevant in attracting international students to Ireland. ${ }^{81}$ Research on the US Study Abroad Programme in Ireland found that while HEls rated university rankings as the second most important reason for choosing Ireland, students interviewed for the research ranked university rankings last among a range of other factors (Southern Cross Consulting, 2018). The other factors listed by students included Ireland's location within Europe, safety and friendliness, culture, the connected history between Ireland and the US, an understandable academic system and curriculum alignment (Southern Cross Consulting, 2018). The OECD and European Commission (2017) and Clarke et al. (2018) report that inward international student mobility in Ireland is also driven by competitive fees for international students in comparison with other Englishspeaking countries.

Enterprise Ireland highlighted that Ireland's global connectivity, exemplified by the presence of multinational companies in Ireland, is also attractive to prospective international students, particularly in relation to employment and internship

80 Interview with Enterprise Ireland, November 2018.

81 Interview with HEA, November 2018; Interview with Enterprise Ireland, November 2018. 
opportunities. ${ }^{82}$ The entitlement to work during and after studies, including the extension of the Third Level Graduate Programme (TLGP) to two years, was also considered important (see Sections 3.2.4 and 4.1). ${ }^{83}$ For postgraduate students in particular, the ability to undertake master's programmes of one year duration was viewed as an attraction. ${ }^{84}$

In this context, government policy has a strong focus on promoting Ireland as a destination for international students (Clarke et al., 2018). A number of initiatives have been introduced, at both national and institutional level, to attract international students to Ireland.

\subsubsection{Marketing and promotion of international higher education}

\section{Education in Ireland}

The marketing and promotion of study opportunities in HEls in Ireland is primarily carried out under the national brand, 'Education in Ireland'. The brand is managed by Enterprise Ireland under the authority of the Department of Education and Skills and is funded by the Department of Education and Skills, HEls, and Enterprise Ireland. ${ }^{85}$ Education in Ireland represents all Irish universities and institutes of technology, in addition to many colleges. The Department of Foreign Affairs and Trade and its network of embassies and consulates also plays a crucial role in promoting Ireland and supporting the development of partnerships between the Irish higher education sector with countries abroad (Department of Education and Skills, 2016a). ${ }^{86}$

Enterprise Ireland has 34 overseas offices around the world, with the head Education in Ireland office based in Dublin and an Education in Ireland office in New York. Education in Ireland representatives are based in Enterprise Ireland offices in key regional markets and education consultants facilitate access to these markets by building relationships with universities, schools and agents (Finn and O'Connell, 2012).

Marketing activity and funding are focused on identified partner countries abroad. In Ireland's first strategy, priority partner countries were identified as the focus for marketing and branding activities (Department of Education and Skills, 2010). ${ }^{87}$ However, the current (2016-2020) strategy states a review will be undertaken to

82 Interview with Enterprise Ireland, November 2018.

83 Interview with Enterprise Ireland, November 2018; Interview with HEA, November 2018; Consultation with HECA, December 2018.

84 Ibid.

85 Interview with Enterprise Ireland, November 2018.

86 Consultation with HEA, April 2019.

87 Interview with Enterprise Ireland, November 2018. 
take into account opportunities to engage with new high potential markets (Department of Education and Skills, 2016a). Key target partner countries are: Brazil, China, the Gulf Region, India, Malaysia and the US. High-potential countries that have been identified for expanding marketing activity include Argentina, Canada, Chile, Indonesia, Mexico, Nigeria, South Korea and Vietnam. ${ }^{88}$ Education in Ireland is also active in Hong Kong, Japan, Sri Lanka and Thailand and looking at opportunities in countries such as Kuwait, Ghana and Colombia. ${ }^{89}$ In order to ensure effective engagement with new partners in addition to existing core partners, the current strategy acknowledges that Education in Ireland, HEls and embassies require adequate resources, noting resources were a challenge for HEls engaging with core partner countries (Department of Education and Skills, 2016a).

\section{Higher education institutions (HEIs)}

HEls also implement international education promotional activities as part of their own internationalisation strategies. HEls receive advice from the HEA and Enterprise Ireland in relation to their internationalisation and marketing strategies (Finn and O'Connell, 2012)..$^{90}$ One HEl consulted for this study noted that promotional activities are targeted towards both HEls and students in key partner countries abroad. ${ }^{91}$

Targeted regions, countries and fields of study vary among HEls. Research commissioned by the HEA in 2018 shows that over two-thirds of HEls surveyed had business plans and marketing strategies targeted towards regions of interest. The research found that the top three regions with which universities had country specific business plans were Asia, North America and the Middle East. The top three regions prioritised by institutes of technology were Asia, North America and Africa, while private colleges tended to focus on Asia and Europe. In particular, China, India, Malaysia and the US featured prominently in the marketing strategies of Irish HEls (Clarke et al., 2018).

Some HEls have a number of global centres around the world to support their marketing activities. For example, University College Dublin (UCD) has global centres based in six cities: Beijing, Chicago, Delhi, Kuala Lumpur, New York and San Francisco. ${ }^{92}$ Partnerships with third countries and campuses abroad also ensure

88 Department of Education and Skills, 'Minister Bruton launches international education strategy', press release, 6 October 2016, available at https://www.education.ie/en/Press-Events/Press-Releases/2016-Press-Releases/PR16-0710.html.

89 Interview with Enterprise Ireland, November 2018.

90 Interview with Enterprise Ireland, November 2018.

91 Consultation with HEI, November 2018.

92 University College Dublin, 'Global centres', available at http://www.ucd.ie/international/global-centres/. 
HEI visibility in such countries; for example, Dublin Business School has a presence in India, China and Malaysia (see Chapter 5)..$^{93}$

While the current strategy does not target specific fields of study, promotional activities conducted by Irish HEls may be targeted towards attracting students to specific fields of education, depending on the market in which the activities are being carried out and individual HEI strategies. Enterprise Ireland observed that science, technology, engineering and maths (STEM) programmes, including cloud computing and financial technology, are a particular focus of promotional activities carried out by HEls at the moment. ${ }^{94}$

Challenges faced by HEls in promoting in international education have been identified. One HEl consulted for the study noted that competition at a domestic level among HEls works against attracting international students. ${ }^{95}$ Clarke et al. (2018) found that HEls were of the general view that Ireland is not well known in key partner countries due to the lack of a coordinated strategic effort at national level and lack of funding made available by the government for promotion. HEls also reported uncertainty with regard to reliance on specific markets and study fields and highlighted the need for cooperation between HEls in relation to engagement in the international sphere. It was suggested that the reliance on student fairs, for which much promotional resources are allocated, should be reviewed (Clarke et al., 2018).

\section{International education fairs}

Education in Ireland, in partnership with Irish HEls, holds education fairs in certain countries and participates in international education fairs. ${ }^{96}$ Between 2013 and 2018, Education in Ireland and HEls took part in several education fairs each year in countries including Brazil, China, India, Indonesia, Malaysia, Mexico, Nigeria, Oman, Saudi Arabia, Sri Lanka, Switzerland, Thailand, the US and Vietnam. ${ }^{97}$

\section{Education missions}

Education missions also form part of Ireland's outreach in third countries. Enterprise Ireland and the Department of Foreign Affairs and Trade have assisted in over 80 such visits and events in core markets since 2010 (Department of Education and Skills, 2016a). These visits and events are often attended at a senior or even ministerial level by the Department of Education and Skills, the Department of Foreign Affairs and Trade and Enterprise Ireland, in addition to HEls and HEI representative bodies. Ministerial presence helps the government, HEls

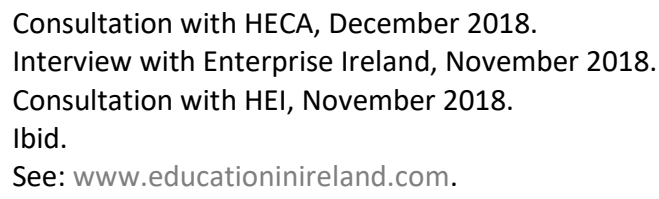


and agencies to effectively establish and improve cooperation with third countries. Many bilateral agreements have been signed at ministerial and HEl level during education missions abroad (see Chapter 5).

\section{Education agents}

HEls in Ireland also recruit international students through education agents. Research shows that HEls view offshore recruitment agencies as effective in supporting their marketing and recruitment of international students (Clarke et al., 2018). The first national strategy stated Ireland would need to develop its capacity to work with ethical and trusted agents on a more strategic basis (Department of Education and Skills, 2010). As a result, the government launched a trusted agents programme operated by Enterprise Ireland in India in 2011 to enhance relationships with education agents and increase the number of Indian students coming to Ireland to study. ${ }^{98}$ The programme allows HEls to liaise with agents who have a proven reputation with education providers. It also provides a means for cooperation between the Department of Justice and agents, who may assist prospective students in submitting visa applications (Finn and O'Connell, 2012).

In 2012, Ireland signed the Statement of Principles for the Ethical Recruitment of International Students by Education Agents and Consultants (known as the London Statement) along with Australia, New Zealand and the UK. ${ }^{99}$ This statement comprises a set of guiding principles that recognise education agents as important stakeholders in international education and seek to promote and encourage a common understanding in the recruitment of international students by education agents and consultants. ${ }^{100}$

\section{Media and digital campaigns}

Digital campaigns represent an increasingly prominent feature of promotional activities in countries abroad. Enterprise Ireland noted that highly effective digital campaigns take place throughout periods of recruitment of international students, featuring content on Irish HEls and promoting specific programmes. ${ }^{101}$ In the past, radio campaigns and newspaper media were utilised to promote educational fairs;

98 Merrion Street, 'Minister Bruton announces moves to increase Ireland's share of 100,000 Indian students for international education sector', available at https://merrionstreet.ie/en/Category-Index/Economy/Business/brutonannounces-moves-to-increase-irelands-share-of-100000-indian-students-for-international-education-sector.html.

99 The London Statement was developed as part of an initiative proposed within the Roundtable on the Integrity of International Education. The Roundtable is a forum of senior education officials established to share knowledge and experience in the area of international education. Ireland takes part in the forum along with Australia, Canada, New Zealand, the UK and the US.

$100 \mathrm{QQI}$, 'Statement of principles for the ethical recruitment of international students by education agents and consultants', available at https://www.qqi.ie/Downloads/London\%20Statement\%20of\%20Principles\%20for\%20Agents.pdf.

101 Interview with Enterprise Ireland, November 2018. 
however, targeted promotional campaigns are now conducted through social media, predominantly via Facebook. ${ }^{102}$

Research on HEl digital marketing practices worldwide found that digital experiences play a significant role for students in their choice of $\mathrm{HEI}$ (TERMINALFOUR, 2018). It was reported that Irish HEls are investing very little in digital marketing campaigns compared to HEls in Australia, Canada, New Zealand, the UK and US and that this should be an area of greater investment (Kelly, 2018b).

\section{The International Student Ambassador Programme}

The International Student Ambassador Programme is another means of promoting international education through the use of digital media. This programme is an initiative of Education in Ireland, and is aimed at promoting international education among students abroad. Student ambassadors share their experience of studying in Ireland through social media. ${ }^{103}$ Currently, 28 higher education institutions are involved in this programme. ${ }^{104}$

\section{Provision of information to international students}

The provision of good quality information to prospective students is an important element in efforts to attract them to Ireland. The Irish Higher Education Quality Network's (IHEQN) Code of practice and guidelines for higher education institutions, which is a set of benchmarks against which HEls measure provision of international education, includes detailed guidelines on the provision of information to international students. It requires HEls to provide comprehensive information to international students and ensure accurate promotion and marketing of education in Ireland. Bodies involved in promoting Irish education should also uphold the standards laid out in this code of practice (IHEQN, 2009).

Similar standards were further set out by QQI in 2015, in its Code of Practice for Provision of Programmes of Education and Training to International Learners. In relation to marketing of international education, a key principle identified in this code of practice requires service providers to conduct recruitment of learners in a transparent and ethical manner. Providers are required to ensure that clear, unambiguous and up-to-date information is provided to students in marketing and promotional materials. Providers must also provide all learners with information on all study and other costs (QQI, 2015).

102 Ibid.

103 Education in Ireland Student Ambassador Programme, 'About', available at http://blog.educationinireland.com/ambassador-programme/.

104 See Education in Ireland Student Ambassador Programme, available at http://blog.educationinireland.com/. 
Enterprise Ireland provides information to prospective international students both in the Education in Ireland brochure and in brochures that target students in different countries, such as China, India and Vietnam, and that are available in different languages, including Arabic and Spanish. ${ }^{105}$ Conditions relating to visas, residence permissions and labour market access are set out by INIS on its website. Detailed information on immigration conditions, course requirements, costs and student supports and services is also available on HEl websites, in addition to the websites of Education in Ireland and ICOS.

A survey of international students who were studying in Ireland in 2015, which was conducted by the National Forum for the Enhancement of Teaching and Learning in Higher Education, found that of the 318 students from non-EU countries surveyed, 237 reported having some, little or no knowledge of immigration policies or procedures in Ireland (Farrelly and Murphy, 2017). Farrelly and Murphy (2017) observed that giving students more detail regarding the systems they will encounter in Ireland would enhance the overall experience of incoming non-EEA students. ICOS observed that students have reported a lack of clarity in relation to student immigration rules, particularly in the context of family reunification entitlements (see Section 3.2.4).

\subsubsection{Scholarships}

Both the previous and current international education strategies have recognised scholarships as a crucial tool in recruiting international students (Department of Education and Skills, 2010; 2016a). Non-EEA students may apply for scholarships made available to non-EEA nationals by the government and HEls, some of which were established with the specific aim of attracting students to Ireland and of supporting Ireland's international development policies. ${ }^{106} \mathrm{It}$ is difficult to ascertain the extent of scholarship support in Ireland. The HEA noted that the system that has been created to manage applications under the Government of Ireland International Education Scholarships programme has been very successful and could offer potential for disseminating information on all relevant scholarship offers. ${ }^{107}$

\section{Government of Ireland International Education Scholarship}

Through the Government of Ireland International Education Scholarship programme, scholarships are awarded to non-EEA students to study full-time in Ireland for a period of one year. The programme is funded by the Department of Education and Skills and HEls and is administered by the HEA. Students are

105 See: Education in Ireland, 'Publications', available at https://www.educationinireland.com/en/Publications/.

106 For further information on scholarships provided by various other HEls in Ireland, see: Education in Ireland, 'Scholarships', available at https://www.educationinireland.com/en/How-Do-I-Apply-/Tuition-CostsScholarships/Scholarships.

107 Consultation with HEA, April 2019. 
awarded $€ 10,000$ by the HEA to cover costs and living expenses for the final year of an undergraduate programme, one year of a taught master's degree programme, or one year of a two-year research master's or three to four year doctoral degree programme. Student tuition and administration fees for that year are also waived by the HEl they attend. ${ }^{108}$ The scholarships were first launched in 2012 as part of Ireland's first strategy as a measure to attract high-calibre international students to Ireland (Department of Education and Skills, 2010). The scholarship is also viewed as a means of increasing linkages with countries in core partner countries and strengthening the internationalisation strategies of HEls (Department of Education and Skills, 2016a). ${ }^{109}$ In this regard, HEls were given the option of re-branding scholarships provided at institutional level as Government of Ireland scholarships to build on their impact (Department of Education and Skills, 2010). Initially provided to 20 individuals, the scholarship is now provided to 60 students as part of the current strategy's aims to increase the number of Government of Ireland scholarships offered (Department of Education and Skills, 2016a). ${ }^{110}$

\section{Claddagh Scholarship Programme}

The Claddagh Scholarship Programme was established by Education in Ireland in September 2015 to promote almost 200 scholarships offered by $17 \mathrm{HEls}$ in Ireland to students from China for courses ranging from undergraduate to doctoral degree level. ${ }^{111}$ This programme also aims to bring together industry partners in Ireland and China who provide opportunities to Chinese graduates to undertake work placements and gain employment following graduation. ${ }^{112}$

\section{Irish Aid Fellowship programme}

Since 1974, Irish Aid, the Irish government's development cooperation programme, led by the Department of Foreign Affairs and Trade, has run an Irish Aid Fellowship programme, which is managed by ICOS and which includes a number of funding streams for eligible applicants.

The Irish Aid Fellowship Training Programme is one stream that provides scholarships to nationals of Cambodia, Eritrea, Ethiopia, Kenya, Laos, Lesotho,

108 HEA, 'Call for applications 2018: Government of Ireland - International education scholarships', available at http://hea.ie/assets/uploads/2018/01/Government-of-Ireland-International-Education-Scholarship-Call-2018-1-1.pdf. ${ }^{109}$ Ibid.

110 Department of Education and Skills, '22 April, 2013 - Minister Quinn launches new Government of Ireland international scholarships to strengthen links with emerging markets', available at https://www.education.ie/en/Press-Events/PressReleases/2013-Press-Releases/PR13-04-22.html.

111 Enterprise Ireland, 'Education mission to China - new Sino-Irish collaborations announced', press release, 27 October 2015, available at https://www.enterprise-ireland.com/en/News/PressReleases/2015-Press-Releases/Educationmission-to-China-\%E2\%80\%93-new-Sino-Irish-collaborations-announced.html.

112 Interview with Enterprise Ireland, November 2018. See also: Education in Ireland, 'Claddagh Scholarship', available at http://www.educationinireland.cn/claddagh_scholarship_programme.html. 
Liberia, Malawi, Mozambique, Myanmar, Palestine, Rwanda, Sierra Leone, Somalia, Sudan, Tanzania, Uganda, Vietnam, Zambia and Zimbabwe. Programme applicants must be working in ministries or civil society organisations. This programme covers course fees, flights, accommodation, monthly allowances, insurance and other incidental expenses. Fellowships are awarded for full-time study at master's level in Ireland and all applicants are required to sign a commitment that they will return to their country of origin within 14 days on completion of their studies to resume work. ${ }^{113}$ ICOS highlighted that the aim of this programme is to invest in students who return to their country of origin and contribute to their own organisation in a development-related area, while also supporting Ireland's overall development objectives. ${ }^{114}$ A number of countryspecific fellowship programmes provide scholarships to students from Burundi, Namibia, Nigeria, Palestine, South Africa, Vietnam and Zambia. ${ }^{115}$ A total of 96 fellowships were awarded in $2018 .{ }^{116}$

Ireland's first international development policy committed to expanding the Irish Aid Fellowship programme to assist students in developing countries to undertake postgraduate studies at HEls in Ireland. The policy also stated that a new stream of fellowships, focusing on vocational and labour market skills, would be developed (Department of Foreign Affairs and Trade, 2013). Following the announcement in 2017 of a new Irish policy for international development, a public consultation paper was published. This paper stated that new elements of Ireland's development policy could include building on postgraduate skills in developing countries through further expansion of the programme (Department of Foreign Affairs and Trade, 2018). ICOS stated that efforts to attract students from emerging markets in Africa, Asia and the Middle East must be balanced with efforts to ensure equal access to higher education by expanding the number of scholarships available to students in developing countries. ICOS therefore welcomed the commitment to expand the Irish Aid Fellowship programme, stating however that it should be clearly aligned with Ireland's development priorities and guided by the United Nation's Sustainable Development Goals, and that least developed countries should be prioritised (ICOS, 2018).

Ireland's new policy for international development introduced in February 2019 states that Ireland will increase the cohort of skilled graduates in developing countries through a revitalised fellowship programme, as part of its commitment to increase support for education (Department of Foreign Affairs and Trade, 2019).

113 Irish Aid Fellowships, 'Fellowship training programme', available at https://www.irishaidfellowships.ie/strands/fellowship-training-programme.

114 Interview with ICOS, October 2018.

115 See: Irish Aid Fellowships, 'Irish Aid fellowship strands', available at https://www.irishaidfellowships.ie/strands.

116 Interview with ICOS, October 2018. 


\subsubsection{Alumni engagement}

International alumni represent a valuable network for Ireland, including in relation to promoting education in Ireland in graduates' home countries (Department of Education and Skills, 2010). A core goal under the current strategy's fourth priority, 'succeeding abroad', is building long-term networks of influence for Ireland through engagement with alumni and diaspora. This commitment also forms part of Ireland's current trade and investment strategy, Ireland connected: Trading and investing in a dynamic world, which sets out the need to build effective engagement with international education graduates (Department of Business, Enterprise and Innovation and Department of Foreign Affairs and Trade, 2017). Alumni are viewed as important actors in promoting education in Ireland and supporting the Education in Ireland brand abroad. The actions set out in the current strategy include using existing networks to facilitate improved networking connections between alumni and HEls, examining practice in other countries relating to engagement with alumni and developing enhanced data on alumni (Department of Education and Skills, 2016a).

HEIs, Enterprise Ireland and the Department of Foreign Affairs and Trade have worked to develop and mobilise alumni networks abroad. The Irish China Alumni Network seeks to maintain a connection with Chinese graduates after they return to China and to develop links between Chinese alumni and Irish companies based in China. ${ }^{117}$ Alumni events are also being explored by Enterprise Ireland in conjunction with the Department of Foreign Affairs and Trade in Bangkok, Toronto and Washington. ${ }^{118}$ Clarke et al. (2018) reported that about one-third of HEls surveyed had established international alumni networks, primarily to seek support from alumni to promote HEls, the largest of which were based in North America and China.

According to ICOS, the Irish Aid Fellowship programme also aims at developing and maintaining alumni networks. ${ }^{119}$ Ireland's new policy for international development states that graduates of this fellowship programme provide an important network for engaging with businesses and governments in developing countries (Department of Foreign Affairs and Trade, 2019). ICOS highlighted the potential role of alumni who return to their country of origin in informing Ireland's development objectives in those countries. ${ }^{120}$

117 Interview with Enterprise Ireland, November 2018.

118 Ibid.

119 Interview with ICOS, October 2018.

120 Ibid. 


\subsection{FACILITATING INTERNATIONAL STUDENT ADMISSION AND STAY}

\subsubsection{Admission conditions}

Non-EEA nationals entering Ireland for the purposes of study are subject to the same general requirements applicable to all non-EEA nationals in relation to visas and residence permission. A number of additional conditions apply specifically to non-EEA students applying for a visa and/or residence permission and are set out in INIS policy documents published since 2011.

Conditions relating to the immigration of international students differ according to whether the non-EU national is a 'degree programme' student, enrolled on a higher education programme at Level 7 of the National Framework of Qualifications (NFQ), or a 'language or non-degree programme' student, enrolled in an English language course or higher education course at NFQ Level 6 (INIS, 2011a; INIS, 2011b; Department of Education and Skills and Department of Justice and Equality, 2015).

\section{Applying for a visa}

Nationals of certain non-EEA countries who wish to enter Ireland and who are enrolled on a course of study of three months or more are required to apply for a ' $D$ ' study visa. ${ }^{121}$ To do so, these non-EEA nationals must submit a number of documents with their application, including:

- a letter of acceptance from the college confirming the applicant has been accepted and enrolled on a full-time course;

- evidence accounting for any gaps in the applicant's educational history;

- evidence college fees have been paid;

- evidence of academic ability to follow the course applied for, such as exam results, qualifications;

- evidence of a minimum standard of English;

- evidence of sufficient funds to support their stay in Ireland - applicants are required to show that they have recourse to a minimum of $€ 7,000$;

- evidence of private medical insurance. ${ }^{122}$

\section{Applying for a student residence permission}

In Ireland, a visa is a form of pre-entry clearance for arrival at the borders of the State. As such, a visa does not automatically grant permission to reside in Ireland. Following arrival in Ireland, both visa-required and non-visa required non-EEA nationals who wish to study for more than three months in the country must

121 For a full list of visa-required nationals, see: INIS, 'Countries that need a visa for Ireland', available at http://www.inis.gov.ie/en/INIS/Pages/visa-required-countries.

122 For a full list of documents required from visa-required nationals in an application for a visa, see: INIS, 'Study', available at http://www.inis.gov.ie/en/INIS/Pages/Study. 
register with the immigration authorities within three months of their arriving in Ireland.

A number of education-based residence permissions for international students are available in Ireland. On registration, the student receives one of three registration stamps, indicating the residence permission granted to the student, in their passport:

- Stamp 1A: non-EEA nationals in full-time, paid accountancy training in Ireland;

- Stamp 2: non-EEA nationals attending a full-time course of study on the Interim List of Eligible Programmes (ILEP); ${ }^{123}$

- Stamp 2A: non-EEA nationals attending courses of study not on the ILEP (for example, students spending a semester in Ireland).

Residence permits granted to undergraduate students are valid for one year and are renewable on an annual basis. Students on taught master's programmes are given a 15-month residence permission to provide for completion of the programme and submission of a thesis. ${ }^{124}$ Residence permits granted to degree programme students are renewable up to a maximum of seven years, provided the student progresses academically (INIS, 2011a). ${ }^{125}$

Initial reforms in 2011 introduced a time limit of three years of residence for nondegree and language students (INIS, 2010). In 2015, further reforms reduced the total permitted length of stay for language students to two years, unless such students are subsequently accepted onto a course at NFQ Level 7 or higher (Department of Education and Skills and Department of Justice and Equality, 2015). Language students are now initially issued with a residence permission for eight months, which is twice renewable (Department of Education and Skills and Department of Justice and Equality, 2015).

Time spent in Ireland on a student residence permission does not count towards eligibility for long-term residence or citizenship. This contrasts with certain other EU Member States that regard time spent in the State as a student as reckonable residence for long-term residence, ${ }^{126}$ or citizenship ${ }^{127}$ (EMN, forthcoming).

123 The ILEP is a list of recognised programmes for student immigration purposes. See INIS, 'Interim List of Eligible Programmes', available at http://www.inis.gov.ie/en/INIS/Pages/Interim\%20List\%20of\%20Eligible\%20Programmes\%20-\%20ILEP.

124 Consultation with INIS, December 2018.

125 Exceptions can be made where the programme is of such duration that it is not possible to finish the course in seven years, or in the case of special circumstances, such as illness (INIS, 2011a).

126 These Member States include Belgium, Croatia, Czech Republic, Estonia, Hungary, Italy, Latvia, Lithuania, Poland, Portugal, Spain and Sweden (doctoral degree students only) and Slovakia.

127 This applies in Finland and Luxembourg. 
In order to be granted a residence permission as a student in Ireland, a student must satisfy a number of conditions (INIS, 2011a; INIS, 2011b; Department of Education and Skills and Department of Justice and Equality, 2015), listed below.

- The student must show they entered the State to engage in full-time study.

- The student must show that they are enrolled on a privately funded course in a higher education degree programme, at NFQ Level 7 or higher, an English language course or a higher education non-degree course leading to an award at NFQ Level 6, included on the ILEP.

- The student must have received a letter of acceptance from the college confirming they have been accepted and enrolled on a full-time course.

- The student must have paid the college fees and received a receipt confirming payment.

- While certain students are permitted to engage in casual employment, they must show they are able to pay for their course, support themselves and live in Ireland without needing a job or to avail of State benefits.

- The student must show that they have access to $€ 3,000$ at the time of registration. ${ }^{128}$

- The student must have private medical insurance, either personally or through a group scheme operated by the college.

\section{Letter of acceptance}

Degree programme students are required to provide a letter of acceptance from their college confirming that they have been accepted and enrolled on a course of full-time education (INIS, 2011a). Language and non-degree programme students are required to provide a letter of acceptance from their college confirming they have been accepted and enrolled on a course of full-time education, involving a minimum of 15 hours organised daytime tuition each week (INIS, 2011b).

\section{Payment of college fees}

Evidence of payment of $\mathrm{HEI}$ tuition fees is also a requirement for obtaining a residence permission. Where fees are below $€ 6,000$, the total amount must be paid in advance. If they amount to over $€ 6,000$, at least $€ 6,000$ must be paid in advance (INIS, 2011a; INIS, 2011b).

Tuition fees for international students in HEls are higher than those for domestic and EEA students, who are entitled to free tuition fees under the Free Fees Initiative (Department of Education and Skills, 2016a). Fees for third-country

128 Visa-required nationals who obtain a study visa are not required to present evidence of finance on registration as they will already have provided such evidence in the process of applying for their visa: INIS, 'Notice regarding evidence of finances for all non EEA students', available at 
nationals are determined at an institutional level, by each individual $\mathrm{HEI}$, and are not a matter for the government (Finn and O'Connell, 2012).

Education in Ireland reported that HEl tuition fees for non-EEA nationals ranged from between $€ 9,950$ to $€ 54,135$ for undergraduate programmes, and between $€ 4,000$ to $€ 48,000$ for postgraduate programmes in the 2018-2019 academic year. ${ }^{129,130}$

In addition to tuition fees, most HEls also charge all their students an annual student contribution charge, or registration fee, which covers student services and examinations. This charge is regulated by the Department of Education and Skills, which has currently set the charge at a maximum of $€ 3,000$ per year.

The first international education strategy noted that in setting tuition fees, a balance should be struck between the impact of higher fees on competitiveness and the need to deliver a high quality of education and exceptional student experience (Department of Education and Skills, 2010). Noting that cost considerations play a role in student decisions to study abroad, the strategy encouraged HEls to compete with global competitors; however, it emphasised that any reduction in fees should not be to the detriment of student supports offered (Department of Education and Skills, 2010). While most other EU Member States impose higher fees for non-EEA students, Ireland reported the highest range of tuition fees for non-EEA nationals and highest administrative fees among EU Member States (EMN, forthcoming).

International students may apply for scholarships to cover all or part of their tuition fees and student contribution charge (see Section 3.1).

\section{English language requirements}

Visa-required nationals applying for a visa to study in Ireland are required to show evidence of English language proficiency, except for applicants entering Ireland for the purposes of attending an English language course. Certification must be provided for immigration purposes as part of the student's application for a visa. ${ }^{131}$ Acceptable English language certificates and the minimum levels of English required of visa applicants are set out by INIS. ${ }^{132}$ Immigration requirements

129 Education in Ireland, 'Non EU undergraduate tuition costs', available at http://www.educationinireland.com/en/HowDo-I-Apply-/Tuition-Costs-Scholarships/Fees-for-Non-EU-Students/Non-EU-Undergraduate-Tuition-Costs. html.

130 Education in Ireland, 'Non-EU postgraduate tuition costs', available at http://www.educationinireland.com/en/HowDo-I-Apply-/Tuition-Costs-Scholarships/Fees-for-Non-EU-Students/Non-EU-Postgraduate-Tuition-Costs.html.

131 INIS, English language requirements for study visas, available at

http://www.inis.gov.ie/en/INIS/English\%20Language\%20Requirements.pdf/Files/English\%20Language\%20Requiremen ts.pdf.

132 Ibid. 
stipulate that certification in English language must have been issued within two years prior to the commencement of the course.

HEls also generally require both visa-required and non-visa required non-EEA students to provide evidence that they meet the English language standard for the course set by the HEI they attend. HEls set their own requirements regarding English language proficiency, which can vary between degree programmes and undergraduate and postgraduate level. Levels required by $\mathrm{HEls}$ are generally higher than those required for obtaining a student visa.

\section{Sufficient funds}

Non-EEA international students are admitted to Ireland for the purposes of study on the condition that they cannot access state benefits (INIS, 2011a; INIS, 2011b). International students must therefore demonstrate that they have access to a sufficient level of resources to support themselves while living in Ireland, and will not need to get a job or avail of state benefits.

What represents 'sufficient resources' varies according to whether the non-EEA student is visa-required or non-visa-required. Visa-required non-EEA students must show that they have access to a minimum of $€ 7,000$ in their application for a visa. They must also show that they have access to a minimum of $€ 7,000$ in addition to course fees for each subsequent year of study in Ireland. ${ }^{133}$ In order to demonstrate access to sufficient funds, visa-required non-EEA students must submit an up-to-date bank statement showing what has been paid into and out of their bank account over the previous six months. ${ }^{134}$ If a family member or friend is responsible for covering costs, or part thereof, evidence must be submitted that proves the relationship and the ability of that sponsor to support the student. Evidence of the relationship of the sponsor to the applicant (such as a birth or marriage certificate) must be submitted, as well as documentation that provides clear details of the ongoing financial support the sponsor intends to provide to the applicant. Evidence as to the availability of such support and evidence that the sponsor has enough funds to maintain themselves and other family members must be submitted; an example here might be a letter from the sponsor's employer confirming employment details and recent payslips. Finally, an up-to-date bank statement is also required of a sponsor, showing what has been paid into and out of their bank account over the previous six months. ${ }^{135}$

133 INIS, Financial requirements for study visas, available at http://www.inis.gov.ie/en/INIS/Information\%20on\%20Student\%20Finances.pdf/Files/Information\%20on\%20Student\% 20Finances.pdf.

134 Ibid.

135 Ibid. 
Visa-required degree programme students may alternatively submit evidence that an education bond has been paid to satisfy the sufficient funds requirement, although INIS observed that this is not common practice. ${ }^{136}$ The use of an education bond is supported by the Irish Naturalisation and Immigration service and allows degree programme students to provide an alternative to bank statements as evidence of sufficient resources. A bond to the amount of $€ 7,000$ must be lodged to an approved student fee payment service, such as that offered by TransferMate. ${ }^{137}$ Receipt of payment of the bond can be submitted as evidence of financial resources with the visa application. The bond is held from the time of the visa application to the time the student registers with immigration in Ireland. The bond is then transferred to the student's Irish bank account on arrival in Ireland. ${ }^{138}$ Education in Ireland note that the bond allows for a swifter visa application process, by reducing the need for financial and sponsor information requests. ${ }^{139}$

Evidence of sufficient funds is also a prerequisite to the granting of a residence permission. Visa-required nationals who obtain a study visa are not required to present evidence of finance on registration as they will already have provided such evidence in their visa application. ${ }^{140}$ Non-EEA nationals who are exempt from applying for a visa to enter Ireland must provide proof of sufficient funds when applying for a residence permission following arrival in Ireland. Such non-EEA students must show that they have access to a minimum of $€ 3,000$ on first registration in the State. In order to demonstrate sufficient funds, visa-exempt non-EEA nationals can provide a statement from an Irish bank account or a current and past foreign bank statement for an account in the students' name accompanied by a debit card for that account. Alternatively, evidence can be provided through documentation showing that money is held in a trust by a financial services body regulated in Ireland, or a pre-paid credit or debit card(s) with a verification of the required amount in credit. ${ }^{141}$ INIS reported that the majority of students provide evidence of sufficient resources by way of a bank statement that details funds in their bank account. ${ }^{142}$

136 Consultation with Policy Division, INIS, December 2018.

137 TransferMate is an approved student fee payments service provider of the Department of Justice and Equality. It is also a service used by many education institutions with regard to the online student application and international fee payment process.

138 Ibid.

139 Education in Ireland, 'EduStep', available at https://www.educationinireland.com/en/how-do-i-apply-/get-yourstudent-visa/for-higher-education/edustep-.html.

140 INIS, 'Notice regarding evidence of finances for all non EEA students', available at http://www.inis.gov.ie/en/INIS/Pages/Notice\%20Regarding\%20Evidence\%20of\%20Finances\%20for\%20all\%20Non\%20 EEA\%20Students.

141 INIS, 'Notice regarding evidence of finances for all non EEA students', available at http://www.inis.gov.ie/en/INIS/Pages/Notice\%20Regarding\%20Evidence\%20of\%20Finances\%20for\%20all\%20Non\%20 EEA\%20Students.

142 Consultation with Policy Division, INIS, December 2018. 


\begin{abstract}
Health insurance
For the purpose of obtaining a residence permission, all non-EEA students are required to provide evidence of private medical insurance. Private medical insurance can be obtained either individually or through a group insurance scheme operated by the student's HEl. Medical insurance must cover accident and/or disease, as well as any period of hospitalisation. Travel insurance may suffice for newly-arrived students in the first year of their course; however, such students must source private health insurance for their subsequent years of study in Ireland. ${ }^{143}$
\end{abstract}

In 2018, requirements concerning the provision of health insurance to international students were the subject of High Court proceedings in Chubb European Group PLC v The Health Insurance Authority. ${ }^{144}$

In line with the Health Insurance Act 1994, as amended, insurers selling health insurance contracts to persons 'ordinarily resident' in the State are required to register with the Health Insurance Authority ( $\mathrm{HIA}$ ) and to comply with the principal requirements set out in the Health Insurance Acts in relation to community rating, open enrolment, lifetime cover and minimum benefits. ${ }^{145,146}$ However, Section 2(1)(d)(i) of the Health Insurance Act 1994, as amended, provides that a contract of insurance provided to persons that are not ordinarily resident in Ireland does not come within the definition of a health insurance contract. The Health Insurance Act of 1994 does not define the meaning of 'ordinarily resident'.

In January 2017, the HIA announced that, according to its interpretation, the term 'ordinarily resident' applies to non-EU students where they are attending a course of study in the State of more than one year's duration. ${ }^{147}$ In March 2017, pursuant to Section 18B of the Health Insurance Act 1994, as amended, the HIA issued an enforcement notice, notifying Chubb that Chubb was in contravention of the Health Insurance Acts by offering its Medicover policy to non-EU students studying in Ireland for more than one year. ${ }^{148}$ The HIA therefore requested Chubb to restrict the offer of its policy to non-EU students studying in Ireland for one year or less in order to comply with the 1994 Act. The HIA had deemed the policy could not be

143 INIS, Private medical insurance for full-time non-EEA students, available at http://www.inis.gov.ie/en/INIS/Private\%20Medical\%20Insurance\%20for\%20full\%20time\%20NonEEA\%20Students.pdf/Files/Private\%20Medical\%20Insurance\%20for\%20full\%20time\%20Non-EEA\%20Students.pdf. 144 [2018] IEHC 609.

145 The HIA is the independent statutory regulator of the private health insurance market in Ireland.

146 Health Insurance Act 1994, ss 7-10 and 14.

147 HIA, 'Non-EEA students studying in Ireland', press release, 25 January 2017, available at https://www.hia.ie/news/noneea-students-studying-ireland.

148 Section 18B of the Health Insurance Act 1994 provides that where the HIA is of the opinion that a person is contravening a relevant provision of the Act, the HIA may serve a notice on the person directing the person to take the necessary steps to remedy the contravention. 
offered to international students unless Chubb complied with the Health Insurance Acts and registered its product with them. Pursuant to Section $18 \mathrm{C}(1)$ of the Health Insurance Act 1994, as amended, Chubb subsequently applied to the High Court seeking to have the enforcement order cancelled.

In the High Court, Chubb submitted that as its Medicover student policy was offered exclusively to non-EU students, which it submitted were not 'ordinarily resident' for the purposes of the 1994 Act, the policy did not amount to a health insurance contract and, accordingly, it was not required to register with the HIA. ${ }^{149}$ However, the High Court held that the HIA had not erred in its determination that non-EU students pursuing a course of study for more than one year in Ireland are to be deemed to be ordinarily resident. ${ }^{150}$

The HIA welcomed the judgment as a confirmation of its interpretation of the term 'ordinarily resident' for the purposes of health insurance provision and its role in enforcing the Health Insurance Acts. ${ }^{151}$ Following the judgment, costs for private health insurance may increase for international students. ICOS stated that as a result of the ruling, private medical insurance for international students may become considerably more expensive, 'potentially adding several thousand euro to the overall cost of study in Ireland, and making Ireland less competitive as a result. ${ }^{\prime 152}$ ICOS further stated that 'there are significant deficits in HIA registered plans from an international student and HEI perspective, including, but not limited to: the absence of cover for repatriation or family support in the case of serious illness or death of the insured; extended waiting periods (usually up to six months) before claims can be made; and the absence of cover for existing conditions' ${ }^{153}$ ICOS highlighted the need for insurance schemes tailored to the circumstances of international students in Ireland. ${ }^{154}$ Students have also expressed concern at the increased financial pressure on international students that may arise following the ruling, noting that students may be faced with private insurance prices of over $€ 1,000$ per year (Kelly, 2018a). A HEl consulted for the study observed that health insurance requirements present a risk to the recruitment of international students across all HEls in Ireland. ${ }^{155}$ The judgment has since been appealed. Pending the outcome of the appeal, the situation relating to costs of medical insurance is

149 Chubb European Group PLC v The Health Insurance Authority [2018] IEHC 609 [13].

150 Ibid [57]

151 HIA, 'High Court Judgment: HIA v Chubb European Group plc', available at https://www.hia.ie/sites/default/files/22.10.2018\%20HIA\%20Court\%20Judgement\%20Press\%20Release.pdf.

152 ICOS, 'ICOS statement on High Court judgement in the case of the Health Insurance Authority (HIA) v Chubb European Group plc on 22 October, 2018', available at https://www.internationalstudents.ie/news/icos-statement-high-courtjudgement-case-health-insurance-authority-hia-v-chubb-european-group.

153 ICOS, 'Statement from ICOS on the HIA ruling regarding private health insurance for non-EEA students', available at https://www.internationalstudents.ie/news/statement-icos-hia-ruling-regarding-private-health-insurance-non-eeastudents.

154 Interview with ICOS, October 2018.

155 Consultation with $\mathrm{HEI}$, November 2018. 
unclear and was identified as an added challenge for HEls providing advice to international students. ${ }^{156,157}$

\section{Visa processing}

Processing times for study visas vary depending on where the application is made. ${ }^{158}$ INIS states on its website that most visas currently take eight weeks to process, following receipt of the application. ${ }^{159}$ Visa applications by degree programme students are fast-tracked. ${ }^{160}$

ICOS observed that universities have in the past raised concerns about visa processing times and the high level of refusals. ${ }^{161}$ One HEl consulted for the study also noted that while study visa approvals used to pose a challenge, the situation has since improved. HEIs, HEI representative bodies and INIS are engaged in an ongoing dialogue on this issue, which is seen to have contributed to improvements in visa processing times. ${ }^{162}$ Urgent appointments can be requested where necessary and may in some cases be sought by HEls on behalf of international students. ${ }^{163}$

Prior to May 2019, visa-required international students were required to apply for a re-entry visa if they intended to travel outside of Ireland for a short period of time. However, on 12 April 2019, the Minister for Justice and Equality announced that the re-entry visa system would be abolished, effective 13 May 2019. From this date an Irish residence permit card, or Garda National Immigration Bureau (GNIB) card, which is granted to non-EEA nationals on registration with INIS/GNIB, will suffice to re-enter Ireland. Prior to its abolishment, the re-entry visa system was a source of concern for students and representative organisations, who noted that it posed an additional administrative burden on students, who may wish to travel home during holiday periods or undertake travel as part of their programme of study, and that it also put pressure on students to secure immigration appointments in good time (Synott, 2018; Civinini, 2018). ${ }^{164}$ The abolishment of the

156 Consultation with IUA, December 2018; Consultation with THEA, December 2018.

157 ICOS, 'Statement from ICOS on the HIA ruling regarding private health insurance for non-EEA students', available at https://www.internationalstudents.ie/news/statement-icos-hia-ruling-regarding-private-health-insurance-non-eeastudents.

158 Consultation with INIS, December 2018.

159 INIS, 'Visa decisions and waiting times', available at http://www.inis.gov.ie/en/INIS/Pages/Current_Processing_Times.

160 Parliamentary Question, 24 October 2012 [43109/12], available at https://www.oireachtas.ie/en/debates/find/.

161 Interview with ICOS, October 2018.

162 Consultation with HEI, November 2018; Consultation with INIS, December 2018; Consultation with IUA, December 2018.

163 Consultation with INIS, December 2018.

164 Interview with ICOS, October 2018. 
re-entry visa system aims to remove the administrative burden from visa-required nationals residing in Ireland and was welcomed. ${ }^{165,166}$

\section{INIS registration appointments}

In 2016, INIS assumed responsibility for the registration of non-EEA nationals resident in Dublin, which was previously the responsibility of the Garda National Immigration Bureau (GNIB). GNIB remains responsible for the registration of nonEEA nationals resident in all other parts of the country. In the same year, INIS introduced an online appointments system, which replaced the queuing and ticketing system that issued appointments on a first-come, first-served basis (Sheridan, 2017). ${ }^{167}$

Stakeholders have raised concerns about the difficulties faced by students in scheduling appointments to register or renew their residence permission at INIS, with students experiencing stress and anxiety in relation to their legal status when delays occur. ${ }^{168}$ ICOS noted that the lack of availability of appointments may result in residence permits granted to students expiring before an appointment to renew the permit has been secured. ${ }^{169}$ Students in the Dublin area report that the online booking system makes it difficult to get a timely appointment to register at INIS, and there are often no available appointments on the system (Bindenagel, 2018). Students have observed that delays in obtaining registration appointments can have a negative impact on their experience of academic life in Ireland (Grossen, 2018). The difficulties students experience with the online system can be exacerbated by the use of 'online bots' by third-party agents to block book appointment slots and to offer appointment slots to non-EU nationals, including international students, for a fee, preventing many individuals from being able to secure appointments on the online system (Pollak, 2018a; Pollak, 2018b). INIS reported that a number of technical fixes have partly addressed this problem. ${ }^{170}$ They have since announced that the current online application system will be replaced in 2019 in order to improve security (Pollak, 2018c). ${ }^{171}$ Alternative systems proposed in the INIS Service Improvement Plan 2018-2020 include the introduction of postal renewal by the third quarter of 2019 for 'low-risk customers', including students on a multi-year degree course (INIS, 2018b).

In an Irish Times letter to the editor, doctoral student Bindenagel suggested that there is insufficient collaboration between the Department of Education and Skills

\footnotetext{
165 INIS, 'Abolition of adult re-entry visas', available at http://www.inis.gov.ie/en/INIS/Pages/abolition-of-adult-re-entryvisas.

166 Consultation with HECA, April 2019.

167 Consultation with INIS, December 2018.

168 Interview with ICOS, October 2018; Interview with Crosscare, October 2018.

169 Interview with ICOS, October 2018.

170 Consultation with INIS, December 2018.

171 Consultation with INIS, December 2018.
} 
and the Department of Justice and Equality to ensure that INIS has the resources necessary to meet the demand for immigration appointments arising from the increased international student targets set out in the current strategy. They recommended that the Department of Justice and Equality streamline the student registration appointment system to address the challenges faced by international students (Bindenagel, 2018). Crosscare, an NGO, noted that the provision of information on how to resolve issues relating to immigration registration and residence permissions may assist non-EEA students. ${ }^{172}$

INIS provided dedicated weekend registration sessions for non-EEA students from October to December 2018, in co-operation with the Irish Universities Association and the Technological Higher Education Association (THEA). ${ }^{173}$ Student appointments were co-ordinated by international student officers in Dublin-based HEls during these sessions. ${ }^{174}$ INIS is currently considering a range of options to improve the registration and renewal processes in advance of the 2019 student peak application period of September to December. ${ }^{175}$

\section{Renewing a student residence permission}

Prior to reform of the student immigration regime in 2011, students could register on an annual basis to renew their residence permission, without any conditions as to the number of renewals permitted (Arnold et al., 2017). However, reforms introduced since 2011 have set out a number of conditions that must be met in order to renew a student residence permission.

Students who wish to renew their residence permission are required to satisfy a number of conditions, including those outlined below (INIS, 2011a; INIS, 2011b; INIS, 2011c; Department of Education and Skills and Department of Justice and Equality, 2015).

- Degree programme students must provide a letter from their college confirming that the student has been engaging in full-time daytime education, that they are progressing academically and have progressed to the next year of the course.

- Language and non-degree programme students must provide a letter from their college confirming that the student has been engaging in full-time daytime education of at least 15 hours per week and confirming a level of 85 per cent attendance. ${ }^{176}$

172 Interview with Crosscare, November 2018.

173 Consultation with INIS, December 2018; Consultation with THEA, April 2019.

174 Consultation with INIS, December 2018.

175 Consultation with INIS, December 2018.

176 INIS, 'Interim List of Eligible Programmes', available at http://www.inis.gov.ie/en/INIS/Pages/Interim\%20List\%20of\%20Eligible\%20Programmes\%20-\%20ILEP. 
- Students must provide proof that course fees have been paid in full to the school/college.

- Students must provide proof that they reside in the State. ${ }^{177}$

- Students must show that they have maintained private medical insurance.

Guidelines set out under the immigration regime for full-time non-EEA students state that permission may be withdrawn if the student breaches any of the above conditions of their student permission (INIS, 2011a; INIS, 2011b).

\subsubsection{Access to orientation supports}

As discussed above, stakeholders consulted for this study placed great emphasis on the quality of the student experience as an important factor in attracting and retaining non-EEA students. ${ }^{178}$ The IHEQN Code of practice and guidelines for Irish higher education institutions concerning the provision of education to international students also stresses the responsibility of HEls to provide a quality service in relation to both academic delivery and pastoral supports (IHEQN, 2009). That code states pre-arrival and post-arrival information should be provided to students and that HEls should provide information, orientation and induction programmes to all new international students. QQI's Code of practice for provision of programmes of education and training to international learners sets out requirements relating to the pastoral care and provision of support to international students by education providers. It states that providers shall foster a supportive environment that supports the well-being and integration of all learners into the student body and ensures a positive learning experience for all learners (QQI, 2015).

HEls surveyed in 2018 reported that they offer a range of supports to international students at institutional, faculty and departmental level, including pastoral care supports (Clarke et al., 2018). The Higher Education Colleges Association (HECA) stated that induction and orientation is a key element of the learner experience and that efforts are made to ensure international students receive relevant information and to integrate national and international students into one student body. ${ }^{179} \mathrm{HEls}$ offer a range of induction, orientation and academic supports to international students. Students may receive advice on opening bank accounts or obtaining health insurance through the HEls international office or student services. Pastoral care is also provided by organisations such as ICOS.

Induction and orientation supports are delivered in a number of ways. For example, Griffith College Dublin has a daily orientation structure that provides

177 Consultation with INIS, December 2018.

178 Interview with HEA, November 2018; Interview with Enterprise Ireland, November 2018.

179 Consultation with HECA, December 2018. 
critical information to international students on arrival, an international induction process that brings together international students in various groups to deliver relevant information, in addition to a general process whereby all students in the $\mathrm{HEI}$ are brought together for a college-wide induction. ${ }^{180}$

Courses, programmes or individual events are offered by many HEls to prepare international students for studying at the HEI in which they are enrolled. HEls also offer English language programmes, in most cases on a fee-paying basis (Clarke et al., 2018). For example, Trinity College Dublin (TCD) runs its English for Academic Purposes programme before the start of the academic term for students and the general public engaging in third level education who wish to improve their academic English skills. TCD also run the Trinity Smart-Start programme one week prior to the start of term to introduce international undergraduate students to academic and social life at the university and in Ireland. ${ }^{181}$

In addition to those based in Ireland, preparatory programmes may also be provided in international students' home countries. Clarke et al. (2018) reported that a higher number of institutes of technology tended to provide pre-arrival orientation supports compared to universities and private colleges. Griffith College Dublin provides such programmes in certain cases to further prepare students for studying in Ireland. For example, lecturers work with partner universities in China to deliver intensive preparatory programmes to assist students with language, culture and study preparation. ${ }^{182}$ Education in Ireland, in conjunction with the Department of Foreign Affairs, has in the past held pre-departure briefings in countries of origin, such as India, to provide information to students and parents in preparation for study in Ireland. ${ }^{183}$ Clarke et al. (2018) reported that international students were in general happy with the orientation experience and supports received. However, international students surveyed commented negatively about access to medical and counselling services available in HEls and were of the view that provision in these areas could be improved (Clarke et al., 2018).

\subsubsection{Accommodation supports}

Ireland's current strategy states that the availability of on-campus student accommodation is an essential element of an institution's internationalisation strategy (Department of Education and Skills, 2016a). The IHEQN noted that due

180 Consultation with HECA, December 2018.

181 See: Trinity College Dublin, 'Pre-orientation programmes', available at https://www.tcd.ie/study/international/presesson-programmes/.

182 Consultation with HECA, December 2018.

183 Education in Ireland, 'Pre-departure briefings - India 2017', available at https://www.educationinireland.com/en/Events/Pre-Departure-Briefings-India-2017.html. 
to linguistic and cultural barriers, as well as a lack of family support networks while abroad, international students require particular assistance with regard to accommodation (IHEQN, 2009). That non-EEA students may lack local knowledge and networks to access private rented accommodation may make them more vulnerable to discrimination and fraud when seeking accommodation. ${ }^{184}$ The IHEQN guidelines therefore state that HEls have a greater duty of care in providing accommodation for international students (IHEQN, 2009). Accommodation supports are provided for international students at an institutional level and vary among HEls. Some HEls offer campus accommodation for which students may apply through the HEl's accommodation service.

Securing accommodation has been highlighted as one of the greatest challenges for international students by HEls and students themselves, in the context of ongoing housing and accommodation shortages and the increase in accommodation costs (Clarke et al., 2018; Fitzgerald, 2017; McGuire, 2016). The increase in students in higher education in Ireland, including international students, has led to an increase in the demand for affordable student accommodation, particularly in Dublin, Cork, Galway and Limerick (Government of Ireland, 2017). In 2015, the HEA reported that both domestic and international students were experiencing difficulties in sourcing affordable accommodation in close proximity to their HEI campus, particularly in the Dublin area (HEA, 2015). A survey of international students on housing in 28 European countries conducted by the HousErasmus+ project found that the UK and Ireland were viewed by international students as the most expensive countries for accommodation (Kuzmane et al., 2017). ${ }^{185}$ In addition, 53 per cent of international students surveyed in Ireland reported that these costs made it difficult to finance their stay in Ireland. Some 28 per cent of the international students surveyed in Ireland reported they had experienced attempted fraud while looking for accommodation, the highest level reported among the 28 countries included in the study (Kuzmane et al., 2017).

In a report on the demand and supply of student accommodation, the HEA recommended that relevant stakeholders work to increase the supply of student accommodation (HEA, 2015). In July 2017, the Government launched the National student accommodation strategy to ensure an increased supply of purpose-built student accommodation to reduce the demand for accommodation in the private rental sector among both domestic and international students attending HEls. The National student accommodation strategy commits to increase bed spaces

184 ICOS, 'ICOS' response to National student accommodation strategy', available at https://www.internationalstudents.ie/news/icos-response-national-student-accommodation-strategy.

185 The countries covered in the survey include Austria, Belgium, Bulgaria, Croatia, Czech Republic, Denmark, Estonia, Finland, France, Germany, Greece, Hungary, Iceland, Ireland, Italy, Latvia, Lithuania, Netherlands, Norway, Poland, Portugal, Romania, Slovakia, Slovenia, Spain, Sweden, Turkey and the UK. 
available to HEls, which is seen as an added attraction for marketing HEls to domestic and international students (Government of Ireland, 2017).

However, stakeholders noted that privately developed purpose-built student accommodation, which is particularly targeted towards international students, is being offered at an unaffordable price for many students (Fitzgerald, 2017; O'Brien, 2018a). ${ }^{186}$ ICOS observed that the prohibitive cost of student accommodation disproportionately affects international students, who tend to opt for purpose-built student accommodation as opposed to the private rental market. ${ }^{187}$ ICOS reported that $\mathrm{HEI}$ accommodation and international offices will require increased resources to meet the increased demand for their services. ${ }^{188}$ One $\mathrm{HEl}$ consulted for the study observed that the shortage of student accommodation in many locations in Ireland may limit growth in the international education sector. ${ }^{189}$

\subsubsection{Accompaniment by family members}

In general, students do not have the right to have their family join them in Ireland. Partners, spouses and children of international students must submit their own visa application, which will be assessed on their own merit. This is subject to certain exceptions, outlined below.

- The student is pursuing a course at doctoral degree level, in which case students are required to show evidence of academic progression and must complete their doctoral degree in four years.

- The student is participating in an academic programme agreed between Ireland and another State, where such an agreement provides an exemption or where the student and dependents have the financial resources to cover expenses in Ireland.

- The student can provide evidence of financial resources on an annual basis to support themselves and their dependents without recourse to public funds or engaging in employment. Such students would need to be pursuing an honours bachelor's degree or higher (INIS, 2016a).

- The student's child is on a short visit to their parents in special circumstances and can guarantee the child will return home following their visit (INIS, 2011a).

Permission to remain for those eligible for reunification will continue to be subject to the requirement that sufficient funding is in place to provide for both the

186 ICOS, 'ICOS' response to national student accommodation strategy', available at https://www.internationalstudents.ie/news/icos-response-national-student-accommodation-strategy.

187 Ibid.

188 Ibid.

189 Consultation with HEI, November 2018. 
student and their dependants and that the student and their dependants will not require access to social welfare benefits (INIS, 2010).

In that context, where a student is accompanied by their children, the child is not permitted to attend state-funded schools and must attend a private fee-paying school (INIS, 2011a). This requirement was introduced to ensure the accompaniment of the student by their children did not bring with it additional costs to the State as a result of the child availing of state education in Ireland (INIS, 2009; Finn and O'Connell, 2012). The introduction of reforms in 2011 included a proposal to introduce an immigration levy to be paid by international students if their child were to attend a state primary or secondary school (INIS, 2010). The introduction of the levy was initially envisioned for the 2012-2013 academic year; however, the levy has yet to be introduced.

ICOS noted a lack of clarity around the application of family reunification rules, which have led to uncertainty for some international students in Ireland. ${ }^{190}$ For example, ICOS noted that as the immigration levy has not been introduced, there is no facility for international students to send their children to state primary or secondary schools. ${ }^{191}$ ICOS also noted that there is a lack of clarity with regard to the level of financial resources required of an international student to support family members who wish to reside in Ireland with the student. ${ }^{192}$ While acknowledging the exemptions provided in certain cases, the Immigrant Council of Ireland called on the Government to at least provide for the possibility of granting children of international students permission to enter and remain on exceptional grounds (Immigrant Council of Ireland, 2009).

\subsubsection{Right to work during studies}

As outlined in Section 2.2, both 'degree programme' and 'language and non-degree programme' non-EEA students on a Stamp 2 permission are permitted to work for up to 20 hours per week during the academic term and up to 40 hours per week on a full-time basis during college holiday periods without needing an employment permit (INIS, 2011a; INIS, 2011b). College holiday periods include the period from 15 December to 15 January and the months of June, July, August and September. ${ }^{193}$ Otherwise known as the student work concession, access to the labour market is

190 Interview with ICOS, October 2018.

191 Ibid.

192 Ibid.

193 INIS, 'Note to employers: Changes to the employment entitlements of non-EEA students holding immigration Stamp 2 with effect from 1 September 2016', available at http://www.inis.gov.ie/en/INIS/Pages/Changes\%20to\%20the\%20Employment\%20entitlements\%20of\%20NonEEA\%20Students\%20holding\%20Immigration\%20Stamp\%202\%20\%E2\%80\%93\%20with\%20effect\%20from\%201\%20Se ptember\%202016. 
viewed by INIS as a concession to assist students to finance their studies and high non-EU fees (Finn and O'Connell, 2012).

Granting non-EEA students access to the labour market is in keeping with competitor countries, who operate similar systems for non-EEA students (Department of Education and Skills, 2010; INIS, 2010; Department of Education and Skills and Department of Justice and Equality, 2014). The 2016 EU Students Directive, which Ireland has not opted into, provides that non-EEA students must be granted permission to work for at least 15 hours per week during the academic year (EMN, forthcoming). ${ }^{194}$

Students on a Stamp 2A permission are not permitted to work. Degree programme students are permitted to undertake an internship or work placement where it forms part of their course (INIS, 2011a), whereas language and non-degree programme students are not permitted to do so (INIS, 2011b). International students are not permitted to be self-employed in Ireland (INIS, 2010).

The NGO Migrant Rights Centre Ireland ( $\mathrm{MRCl}$ ) expressed the view that employers circumvent restrictions on the issuing of work permits in low-paid sectors and seek to fill labour shortages through employment of non-EEA students ( $\mathrm{MRCl}, 2015$ ). $\mathrm{MRCl}$ found that non-EEA students availing of their service tend to be employed in part-time work in sectors in which they are particularly vulnerable to exploitation, including: hotel, restaurant and catering; service and retail; cleaning and maintenance; and domestic and care work (MRCl, 2015; Gilmartin et al., 2016). While recent reforms have sought to tighten the student immigration regime, Arnold at al. (2017) observed that work outside of the permitted hours is still a common feature of student immigration in Ireland. Smith (2012) reported that non-EEA students working as au pairs were typically working above 40 hours per week, beyond the permitted hours. Such workloads were observed to be a significant stress for students and to impact on college attendance, which placed them at risk of losing their student permission (Smith, 2012; Gilmartin et al., 2016).

194 Directive (EU) 2016/801 of the European Parliament and of the Council of 11 May 2016 on the conditions of entry and residence of third-country nationals for the purposes of research, studies, training, voluntary service, pupil exchange schemes or educational projects and au pairing, Article 24. 


\section{CHAPTER 4}

\section{Retaining students: Facilitating stay and access to employment after studies}

The current international education strategy (2016-2020) identifies highly skilled international students as a group making an important contribution to Ireland's talent pool. International students are seen to bring additional language skills and knowledge of overseas markets, and their retention in Ireland is also seen to enhance workplace diversity (HEA, 2019). One of the objectives of the strategy is therefore to retain international graduates. The existence of opportunities to stay in Ireland after studying also contributes to Ireland's overall attractiveness as a destination for non-EEA students.

Literature on the internationalisation of higher education has highlighted concerns that internationalisation, and the recruitment and retention of international students, may lead to a 'brain drain' for sending countries (Courtois, 2017). Ireland's first strategy (2010-2015) highlighted the importance of capacity building in developing countries and stated that internationalisation must be consistent with Ireland's foreign policy and development programme (Department of Education and Skills, 2010). Ireland's current strategy acknowledges that in implementing internationalisation objectives, an ethical approach to the internationalisation of higher education must be adopted, one that balances responsiveness to local, regional and national needs with international competitiveness (Department of Education and Skills, 2016a).

Under the Third Level Graduate Programme (TLGP), non-EEA graduates at Level 8 of the National Framework of Qualifications (NFQ) can stay up to 12 months in Ireland following graduation, while those at Level 9 or above can stay up to 24 months. Non-EEA students who do not qualify for the TLGP in Ireland may be granted permission to stay if they have secured employment through the employment permit system. The current national skills strategy commits to examining the role of the TLGP and the employment permit system in this context (Department of Education and Skills, 2016b).

This chapter explores the conditions that apply to students following completion of their studies and the measures in place to encourage students to remain in Ireland to pursue employment or other activities. Section 4.1 examines permission to remain for the purposes of seeking employment under the TLGP, while Sections 4.2 to 4.5 examines the pathways to employment available to non-EEA students through the employment permit system, research hosting agreements, the Startup Entrepreneur Programme, and assistance provided to students by HEls. 


\subsection{THIRD LEVEL GRADUATE PROGRAMME (TLGP)}

The TLGP provides for non-EEA graduates who have completed their studies in Ireland and been awarded a qualification at NFQ Level 8 or above to remain in Ireland after their studies for the purpose of seeking graduate-level employment and applying for an employment permit (INIS, 2017). Under the TLGP, graduates may be employed on a full-time basis and are not subject to restrictions on working hours. In addition, graduates granted permission under TLGP are not required to hold an employment permit to engage in employment (INIS, 2017). However, graduates are not permitted to operate a business or to be self-employed during the period of time spent in Ireland under this programme (INIS, 2017). The TLGP is viewed as a primary measure to both attract students to Ireland and to retain them following graduation. ${ }^{195}$ Emphasis is placed on ensuring enterprises can retain skilled non-EEA international students following qualification in Ireland. ${ }^{196}$

Graduates who have obtained an award at NFQ Level 8 may be granted permission to reside for up to 12 months under the TLGP. This is subject to an overall seven year limit on residence in Ireland, under a Stamp 2 permission as a student and a Stamp 1G permission as a graduate.

Graduates who have obtained an award at NFQ Level 9 and above can remain in Ireland for a period of up to two years, subject to an overall eight year limit on residence in Ireland, under a Stamp 2 permission as a student and a Stamp 1 G permission as a graduate (INIS, 2017). Such graduates are initially granted a 12 month permission, which is renewable for a second 12 month period where the graduate shows that they have taken appropriate steps to secure graduate-level employment.

The granting of permission to non-EEA students for the purposes of seeking employment after graduation is in line with practice in other EU Member States. The EU 2016 Students Directive, into which Ireland has not opted, stipulates that non-EEA students should be permitted to remain in a Member State for a period of at least nine months in order to seek employment or to set up a business. ${ }^{197}$ The period of time during which non-EEA students are permitted to stay following graduation varies across other EU Member States that are bound by the Directive. Some 16 Member States grant such permission for periods of nine to 18 months (EMN, forthcoming). ${ }^{198}$ However, in seven of these Member States, non-EEA

195 Consultation with HEA, December 2018.

196 Parliamentary Question, 3 May 2018 [19546/18], available at https://www.oireachtas.ie/en/debates/find/.

197 Directive (EU) 2016/801 of the European Parliament and of the Council of 11 May 2016 on the conditions of entry and residence of third-country nationals for the purposes of research, studies, training, voluntary service, pupil exchange schemes or educational projects and au pairing, Article 25.

198 In seven Member States - Bulgaria, the Czech Republic, Estonia, Hungary, Latvia, Luxembourg and Slovakia - the time limit is nine months. In a further eight Member States - Austria, Finland, France, Lithuania, the Netherlands, Poland, 
graduates are not permitted to work while residing in the State on a graduate permission. ${ }^{199}$ Ireland stands out in this regard in offering graduates with a degree at NFQ Level 9 or above the possibility of remaining in Ireland for up to a further two years.

Concerns have been expressed in media reports about the lack of awareness among some employers regarding the stamp system and non-EEA students' entitlement to work under the TLGP (Pollak, 2019). Stamp 1G was introduced in 2016 as a separate category for graduates on that programme, in an effort to assist employers differentiate between graduates and students on a Stamp 2 permission with conditions as to their access to the labour market (see Section 2.2.4). However, non-EEA students have reported difficulties in applying for jobs, observing that employers tend to think that only non-EEA nationals on a Stamp 4 permission are entitled to work (Pollak, 2019).

In 2012, 653 residence permissions were granted to non-EEA graduates availing of the TLGP (Finn and O'Connell, 2012). Available data on graduates granted a Stamp $1 \mathrm{G}$ since its introduction in 2016 show that 1,473 non-EEA graduates were granted a Stamp $1 \mathrm{G}$ in 2016, increasing to 2,089 in $2017 .^{200}$

At the end of the period during which an international graduate is permitted to stay in Ireland with a Stamp 1G permission, international graduates must have secured employment on the basis of a general employment permit, critical skills employment permit or research hosting agreement, in order to be permitted to continue residing in Ireland.

\subsection{GENERAL EMPLOYMENT PERMIT AND CRITICAL SKILLS EMPLOYMENT PERMIT}

The General Employment Permit allows non-EEA nationals to work in Ireland for an employer in a particular occupation, apart from occupations on the Ineligible Categories of Employment List (ICEL), which lists occupations for which employment permits may not be issued. ${ }^{201}$ Such permits can be issued for a period of two years, following which it may be renewed for a further three years. The general minimum annual remuneration for applying for a general employment permit is set at $€ 30,000$. However, a lower annual remuneration of $€ 27,000$ was

Portugal and Spain - it is 12 months. In Germany, graduates are permitted to stay on a graduate residence permit for up to 18 months.

199 These Member States are Austria, Finland, Hungary, Latvia, Lithuania, Luxembourg and Spain.

200 Consultation with INIS, November 2018.

201 Department of Business, Enterprise and Innovation, 'Ineligible categories of employment for employment permits', available at https://dbei.gov.ie/en/What-We-Do/Workplace-and-Skills/Employment-Permits/Employment-PermitEligibility/Ineligible-Categories-of-Employment/. 
introduced in 2013 for categories that include non-EEA students who have graduated in the last 12 months from an Irish third-level institution and have been offered a position from the Critical Skills Occupations List (CSOL) (Joyce and Gusciute, 2015). In such cases, annual remuneration must be $€ 30,000$ at the time of renewal of the permit. ${ }^{202}$ The CSOL is a list of occupations for which there is a shortage in qualifications, experience or skills and that are deemed to be of strategic importance to economic growth. Occupations listed on the CSOL include business, research and administrative professionals, ICT professionals, health professionals, engineers and scientists. ${ }^{203}$

The Critical Skills Employment Permit is designed to attract highly skilled people to the labour market, with the aim of encouraging them to take up permanent residence in Ireland. Such permits are issued for highly skilled occupations deemed to be of critical importance to the economy and for which there is a significant shortage of supply. Eligible occupations include occupations with a minimum annual remuneration of $€ 30,000$ listed on the CSOL and other occupations with a minimum annual remuneration of over $€ 60,000$, apart from those included on the ICEL. Such permits are issued on the basis of a job offer of at least two years in a particular occupation. After two years on a Critical Skills Employment Permit, nonEEA nationals may apply for a Stamp 4 permission to live and work in Ireland without the need for an employment permit.

The application of reduced criteria for graduates applying for a General Employment Permit has been welcomed. ${ }^{204}$ However, Crosscare observed that the minimum income thresholds for employment permits may pose difficulties for recently graduated non-EEA students seeking employment. ${ }^{205}$ ICOS expressed concerns that the minimum income thresholds are prohibitive for graduates, who may require more than one year to achieve enough experience to earn a sufficient income (Finn and O'Connell, 2012). The OECD recommends that the time allowed for graduates to remain in Ireland and work following their studies should be increased (OECD and European Commission, 2017). The Migrant Rights Centre Ireland $(\mathrm{MRCl})$ recommended the introduction of measures help maximise the skills that students bring and those they acquire in Ireland, such as facilitating entry to the employment permits system through a different salary threshold ( $\mathrm{MRCl}$, 2015).

202 Department of Business, Enterprise and Innovation, 'General employment permit', available at https://dbei.gov.ie/en/What-We-Do/Workplace-and-Skills/Employment-Permits/Permit-Types/General-EmploymentPermit/.

203 Department of Business, Enterprise and Innovation, 'Highly Skilled Eligible Occupations List', available at https://dbei.gov.ie/en/What-We-Do/Workplace-and-Skills/Employment-Permits/Employment-Permit-Eligibility/HighlySkilled-Eligible-Occupations-List/.

204 Interview with Crosscare, November 2018.

205 Interview with Crosscare, November 2018. 
Finn and O'Connell (2012) reported that a total of 88 non-EEA graduates on a student permission were granted an employment permit in 2011, while 44 were granted one in 2012. Table 3.1 shows that the annual number of non-EEA graduates who have secured an employment permit following graduation increased significantly between 2013 and 2017.

TABLE 4.1

EMPLOYMENT PERMITS GRANTED TO NON-EEA GRADUATES, 2013-2017

\begin{tabular}{l|c|c|c|c|c|}
\hline Year & 2013 & 2014 & 2015 & 2016 & 2017 \\
\hline Total & 48 & 550 & 566 & 743 & 871 \\
\hline
\end{tabular}

\subsection{RESEARCH HOSTING AGREEMENTS}

International graduates may be granted permission to remain for employment with an accredited research institution on the basis of a Hosting Agreement, in line with Council Directive 2005/EC/71. ${ }^{206}$ All seven Irish universities, 11 institutes of technology and several research organisations and industrial organisations are currently accredited to issue Hosting Agreements to non-EEA researchers. ${ }^{207}$ Such agreements allow institutions to avail of a fast-track procedure to admit non-EEA nationals to Ireland for the purposes of research and employ non-EEA researchers without the need for an employment permit. Following two years working in Ireland on the basis of a Hosting Agreement, non-EEA nationals may be granted a Stamp 4 residence permission.

EURAXESS Ireland, administered by the Irish Universities Association (IUA), process Hosting Agreements on behalf of the Department of Business, Enterprise and Innovation. Graduates seeking employment in a research institution may also avail of assistance from EURAXESS Ireland in relation to developing connections with potential employers and advice on immigration-related matters. ${ }^{208}$ The IUA highlighted the success of the fast-track system in place for securing residence under the Hosting Agreement Scheme. ${ }^{209}$ A survey of researchers on Hosting Agreements, conducted by EURAXESS in 2013, found that 40 per cent of researchers surveyed were already living in Ireland when they applied for research

\footnotetext{
206 Department of Business, Enterprise and Innovation, 'Scheme for Accreditation of Research Organisations (Hosting Agreement Scheme)', available at https://dbei.gov.ie/en/What-We-Do/Innovation-Research-Development/HostingAgreement-Scheme/; INIS, 'Researchers (on a hosting agreement)', http://www.inis.gov.ie/en/INIS/Pages/Researchers.

207 As of May 2019, 68 research organisations, including several HEls, are accredited to issue Hosting Agreements to researchers from non-EEA countries. See: Department of Business, Enterprise and Innovation, 'List of accredited research organisations', available at https://dbei.gov.ie/en/What-We-Do/Innovation-Research-Development/HostingAgreement-Scheme/List-of-Accredited-Research-Organisations.html.

208 For further information, see https://www.euraxess.ie/.

209 Consultation with IUA, December 2018.
} 
posts, of whom 60 per cent held doctoral degrees obtained at an Irish HEI and 13 per cent had obtained a master's degree at an Irish HEI (EURAXESS, 2013).

\subsection{START-UP ENTREPRENEUR PROGRAMME}

Non-EEA students can apply to set up a business through the Start-up Entrepreneur Programme (STEP). STEP was introduced in January 2012 to attract third-country national entrepreneurs to Ireland and to stimulate productive investment in the State. Under this scheme, third-country nationals with a proposal for a high potential start-up and funding of $€ 50,000$ may be given residency under for the purposes of developing their business. A high potential start-up must:

- introduce a new or innovative product or service to international markets;

- be capable of creating at least ten jobs in Ireland and realising at least $€ 1$ million in sales within three to four years;

- be led by an experienced management team;

- be headquartered and controlled in Ireland;

- be less than six years old.

The STEP scheme does not apply to retail, personal services, catering or other such businesses (INIS, 2016b).

In 2014, a 12-month immigration permission was introduced to enable thirdcountry national entrepreneurs to attend innovation bootcamps or incubators in Ireland in order to help them to prepare a STEP application. This permission is available to non-EEA students who graduate with advanced science, technology, engineering or mathematics (STEM) degrees in Ireland and who wish to prepare a STEP application. ${ }^{210}$

The Immigrant Council of Ireland noted that increased efforts should be made to target STEP at non-EEA students (Gusciute et al., 2015). The 2015 action plan for jobs included the promotion of STEP (Department of Business, Enterprise and Innovation, 2015a). The first progress report noted that a seminar with the first group of targeted students had taken place, as well as further road show events throughout 2015 (Department of Business, Enterprise and Innovation, 2015b).

210 INIS, 'Minister Shatter announces targeted changes in the Start-up Entrepreneur Programme', available at http://www.inis.gov.ie/en/INIS/Pages/Minister\%20Shatter\%20announces\%20targeted\%20changes\%20in\%20the\%20St art-up\%20Entrepreneur\%20Programme. 


\subsection{SUPPORT PROVIDED BY HIGHER EDUCATION INSTITUTIONS}

The HEI provides support aimed at facilitating international students to seek employment opportunities following completion of their studies. ${ }^{211} \mathrm{HEI}$ career offices provide training and support to graduates with a view to obtaining employment through the development of soft skills and job preparedness skills. ${ }^{212}$ Individual academic departments may also assist students to secure work placement or employment following graduation. ${ }^{213}$ One HEI consulted for the study stated that their international office provides briefings to non-EEA students on the TLGP. ${ }^{214}$ The provision of information by HEl career offices to employers, on the TLGP and other employment routes for non-EEA students, was highlighted as good practice, particularly in terms of reducing barriers to employment for nonEEA students, of whose entitlements employers may not be aware. ${ }^{215}$

211 Consultation with THEA, December 2018; Consultation with HECA, December 2018.

212 Consultation with HECA, December 2018.

213 Consultation with HEI, November 2018; Consultation with THEA, December 2018.

214 Consultation with HEI, November 2018.

215 Consultation with HECA, December 2018. 


\section{CHAPTER 5}

\section{Cooperation with non-EEA countries on higher education}

Cooperation with third countries in the area of international education takes many forms, including bilateral and multilateral agreements signed by the State and HEls with governments and HEIs in non-EEA countries. Irish HEls have also developed global relationships by establishing campuses overseas and offering programmes in partnership with institutions and providers abroad.

The current international education strategy (2016-2020) acknowledges that the Department of Education and Skills and the Department of Foreign Affairs and Trade have been highly successful in assisting the building of long-term partnerships at national and institutional level in partner countries (Department of Education and Skills, 2016a). Enterprise Ireland observed that institutional engagements worldwide continue to increase in line with the objectives of the current strategy. ${ }^{216}$

Section 5.1 discusses bilateral agreements between the Irish State and HEls and governments and HEls in non-EEA countries, which facilitate mobility of non-EEA students and contribute to internationalisation in Ireland. Section 5.2 provides an overview of some examples of the provision of education by Irish HEls in non-EEA countries.

\subsection{BILATERAL AGREEMENTS BETWEEN IRELAND AND THIRD COUNTRIES}

Finn and O'Connell (2012) reported that there is little collated information available on agreements signed at national and institutional level. It has also been found that the extent to which educational institutions collate such information varies among higher education institutions (HEls), with some HEls reporting that such information is not centralised at institutional, school or departmental level (Clarke et al., 2018).

\subsubsection{Agreements at national level}

An unknown, but significant, number of arrangements are in place between the Irish State and third countries relating to international education. Partnerships have been established with countries in key markets where Ireland has been promoted as a destination for international students.

216 Interview with Enterprise Ireland, November 2018. 
During the study period, agreements were signed with countries such as Bolivia, China, Indonesia and Oman. ${ }^{217,218,219,220}$ Such partnerships generally take the form of memorandums of understanding, which are seen to facilitate the deepening of relationships between both countries while promoting student exchange. ${ }^{221}$

As outlined in Section 3.1.1, bilateral agreements between Ireland and non-EEA countries may be signed at ministerial level during education missions undertaken by the Minister of Education and Skills and government officials, with the assistance of Enterprise Ireland. Memorandums are also signed at ministerial level during visits of ministers from third countries to Ireland, such as a memorandum of cooperation signed by the Minister for Education and Skills and Japan's Minister of Education, Culture, Sports, Science and Technology in May 2013..$^{222}$

The HEA reported that, in its role as national agency for Erasmus+, it has been engaged in promotional activities since 1987. Each year, it receives a number of foreign delegations keen to partner with Ireland. It also engages in a number of bilateral arrangements with a focus on building collaboration. ${ }^{223}$

Enterprise Ireland stated that a top-down approach is taken in developing partnerships in certain markets. ${ }^{224}$ In such cases, agreements made initially at ministerial level facilitate the subsequent development of relationships between HEls and representative bodies in Ireland and non-EEA countries. ${ }^{225}$

\subsubsection{Agreements at institutional level}

Bilateral agreements include memorandums of understanding and partnership agreements between Irish HEls and non-EEA HEls, which provide the opportunity for HEls to establish and develop links with HEls abroad and facilitate student

217 HEA, 'Interinstitutional cooperation agreement on higher education between the Higher Education Authority, Ireland and the Ministry Of Education, Plurinational State of Bolivia', available at http://eurireland.ie/assets/uploads/2017/06/09_Final-Draft-of-MOU.pdf.

218 Department of Foreign Affairs and Trade, 'Minister Flanagan signs agreement to boost links with China', 9 December 2014, available at https://www.dfa.ie/news-and-media/press-releases/press-releasearchive/2014/december/minister-flanagan-china/.

219 Department of Education and Skills, 'Minister Bruton leads education and trade mission to Malaysia and Indonesia', 15 September 2018, available at https://enterprise-ireland.com/en/News/PressReleases/2018-Press-Releases/MinisterBruton-concludes-5-day-Enterprise-Ireland-education-mission-to-Indonesia-and-Malaysia.html.

220 Department of Education and Skills, 'Minister for Higher Education, Mary Mitchell O'Connor, T.D. and her counterpart the Minister of Higher Education, H.E. Dr Rawya Al Busaidi sign a memorandum of understanding', 14 May 2018, available at https://www.education.ie/en/Press-Events/Press-Releases/2018-press-releases/PR18-05-14-1.html.

221 Department of Education and Skills, 'Minister Bruton leads education and trade mission to Malaysia and Indonesia', 15 September 2018, available at https://enterprise-ireland.com/en/News/PressReleases/2018-Press-Releases/MinisterBruton-concludes-5-day-Enterprise-Ireland-education-mission-to-Indonesia-and-Malaysia.html.

222 HEA, 'Partnership for innovation and growth: Joint declaration by the Prime Minister of Japan and the Taoiseach of Ireland', available at http://eurireland.ie/assets/uploads/2017/06/13_Joint-Declaration-signed-by-Taoiseach-2013.pdf

223 Consultation with HEA, April 2019.

224 Interview with Enterprise Ireland, November 2018.

225 Ibid. 
mobility. HEI representative bodies also enter into agreements with similar representative bodies and government agencies abroad on behalf of their members, in order to facilitate institutional engagement. ${ }^{226}$

Finn and O'Connell (2012) noted that many Irish HEls reported that they had established links or partnerships with HEls in Australia, Canada, China, India, Japan and the US. As of 2016, at least 160 agreements between Irish HEls and HEls in China were reportedly in place. ${ }^{227} \mathrm{HEls}$ may establish partnerships with HEls in third countries during education missions led by the Minister for Education and Skills. For example, in 2018, seven Irish HEls each signed bilateral agreements with HEls in Indonesia and Malaysia during an education and trade mission to both countries. ${ }^{228}$ In March 2019, four Irish HEls also signed memorandums of understanding with Chinese HEls during an education mission to China. ${ }^{229}$

The development of partnerships with HEls in third countries is dependent on the priorities, or strategies, of individual HEls. One HEI consulted for the study noted that it had in place several hundred agreements with HEls from non-EEA countries, which form the basis for mobility, academic cooperation, research collaboration and/or joint programmes. The same HEI also reported that in most instances, academic disciplines are specified or proposed. ${ }^{230}$ Another $\mathrm{HEI}$ consulted for this study reported that agreements with HEls in non-EEA countries typically consist of academic mapping/articulation. ${ }^{231}$

Some HEls reported experiencing challenges in the implementation of international agreements. For example, agreements can require a significant amount of time and effort to put in place. Many students access Irish universities on the basis of such arrangements; however, it was noted that agreements may take a year to be finalised and it can take one or two years before the first students arrive. Consequently, it may take some time before HEls experience a growth of international students arising from partnerships with non-EEA HEls. Another difficulty highlighted by HEls was that of ensuring collaboration actually takes place, in practice, and providing the means for college or faculty level engagement once an agreement at institutional level has been signed (Clarke et al., 2018).

226 Consultation with THEA, April 2019.

227 Department of Foreign Affairs and Trade, 'Year in review 2016: Trade missions', available at https://www.dfa.ie/annualreport/2016/our-prosperity/trade-missions/.

228 Department of Education and Skills, 'Minister Bruton leads education and trade mission to Malaysia and Indonesia', 15 September 2018, available at https://enterprise-ireland.com/en/News/PressReleases/2018-Press-Releases/MinisterBruton-concludes-5-day-Enterprise-Ireland-education-mission-to-Indonesia-and-Malaysia.html.

229 Department of Education and Skills, 'Minister McHugh witnesses signings of MoUs between Irish and Chinese higher education institutions in Beijing', press release, 18 March 2019, available at https://www.education.ie/en/PressEvents/Press-Releases/2019-press-releases/PR19-03-18.html.

230 Consultation with HEI, November 2018.

231 Consultation with $\mathrm{HEI}$, November 2018. 
According to HEls consulted for this study, quality control, sustainable implementation, funding, and governance are some of the challenges experienced in relation to bilateral and multilateral agreements. ${ }^{232}$

\subsubsection{Other agreements}

\section{Agreements concerning recognition of qualifications}

There are a number of bilateral agreements in place that support the recognition of qualifications between Ireland and non-EEA countries, such as Australia and New Zealand. Most are in the form of a memorandum of understanding, aimed at strengthening collaboration, mutual recognition of qualifications and facilitating mobility among international students. Memorandums are mainly signed by Quality and Qualifications Ireland (QQI) and their equivalent in the partner country, such as the Malaysian Qualifications Agency and the China Education Association for International Exchange. ${ }^{233} \mathrm{QQI}$ is also part of the Cross Border Quality Assurance Network, which is a quality assurance network for higher education in Asia and Europe. ${ }^{234}$ In September 2016, a memorandum of understanding was signed between $\mathrm{QQI}$ and the Education Bureau of the Hong Kong Special Administrative Region, which aimed, among other things, to facilitate the mobility of students between Ireland and Hong Kong. ${ }^{235}$ The partnership has also facilitated the publication of a user guide to help students compare qualifications achieved in Hong Kong and Ireland. ${ }^{236}$

\section{Erasmus+ programme}

The Erasmus+ programme is the EU programme for education, training, youth and sport, which includes support for non-EEA nationals to undertake exchange programmes or a programme of higher education in EU countries. Despite its focus on mobility throughout the EU, non-EEA countries can participate if they fulfil certain conditions and criteria. Bilateral agreements form the basis of all partnerships with third countries under the Erasmus+ programme. ${ }^{237}$ The HEA reported in 2017 that a total of 15 Irish HEls participate in the Erasmus+ programme, facilitating student and staff mobility to and from 51 countries outside the EEA (HEA, 2017c).

232 Correspondence with HEls, November 2018.

$233 \mathrm{QQI}$, 'International agreements', available at https://www.qqi.ie/Articles/Pages/MOUs-and-Bilateral-Agreements.aspx.

234 lbid.

$235 \mathrm{QQI}$, 'Towards mutual recognition of qualifications between Ireland and Hong Kong', available at https://www.qqi.ie/News/Pages/Towards-Mutual-Recognition-of-Qualifications-between-Ireland-and-Hong-Kong.aspx. 236 Ibid.

237 Consultation with HEA, December 2018. 


\subsection{PROVISION OF TRANSNATIONAL HIGHER EDUCATION}

Both Ireland's first strategy on international education and the current strategy have observed a significant growth worldwide in transnational education, which stems from the bilateral cooperation discussed in Section 5.1. Both strategies have also reported that Irish HEls were involved in the provision of transnational education through overseas campuses, joint degree programmes and delivery of programmes overseas (Department of Education and Skills, 2010; 2016a). The first strategy noted that further development of transnational education and the increased use of flexible learning (such as e-learning and blended learning) had good potential to contribute to internationalisation and recommended that transnational education be included in institutional internationalisation strategies (Department of Education and Skills, 2010). The current strategy includes provision of transnational higher education as part of its strategic priority to create HEls that are internationally oriented and globally competitive (Department of Education and Skills, 2016a).

Offshore campuses and distance learning can be attractive to international students as they involve lower costs than studying abroad (Department of Education and Science, 2004). However, Ireland's current strategy acknowledges that providers offering courses in areas of high demand could negatively impact on indigenous institutions, and emphasises the need to ensure an ethical approach to internationalisation to mitigate inequalities between the developed and developing world (Department of Education and Skills, 2016a).

The Department of Education and Skills (2016a) reported that 2,628 students were registered in offshore Irish programmes or campuses overseas for the 2014-2015 academic year, which the current strategy seeks to increase further by 2020 .

\subsubsection{International branch campuses}

There are approximately 240 international branch campuses worldwide. ${ }^{238}$ To date, three Irish HEls have been involved in the establishment of five branch campuses abroad. These include: the Royal College of Surgeons in Ireland (RCSI) Bahrain founded in 2012; RCSI Dubai founded in 2005; the Beijing-Dublin International College established in 2012 by University College Dublin (UCD) and Beijing University of Technology; the RCSI and UCD Malaysia Campus in Penang, Malaysia launched in September 2018; and the launch in October 2018 by

238 ICEF Monitor, 'A more cautious outlook for international branch campuses', available at http://monitor.icef.com/2015/10/a-more-cautious-outlook-for-international-branch-campuses/; Cross-Border Education Research Team, 'Branch Campuses', available at http://cbert.org/resources-data/branch-campus/. 
Maynooth University of the Maynooth International Engineering College in Fuzhou University, China. ${ }^{239}$

\subsubsection{Delivery of programmes overseas}

HEls also participate in the delivery of joint and distance education programmes in countries abroad (Clarke at al., 2018).

The majority of institutions surveyed by Clarke et al. (2018) engaged in bilateral academic credit recognition, allowing international students to undertake a portion of the programme offshore prior to enrolling in the HEl in Ireland. Delivery of the HEI's own qualifications, or part thereof, in HEls overseas is also a feature of HEl activity abroad. An example of such cooperation is Dublin Business School's partnership with Kolej Poly-Tech Mara in Malaysia, which provides for Malaysian students to obtain an Irish undergraduate qualification in Malaysia and subsequently continue education in Ireland with a view to completing a professional accountancy qualification. ${ }^{240}$ Most recently, in 2018, Athlone Institute of Technology (AIT) and Jianghan University in China launched a joint graphic design bachelor's degree programme, which offers students the opportunity to study in Ireland for the final year of the programme. ${ }^{241}$ Enterprise Ireland noted that over 50 per cent of Chinese students that study in Ireland do so as a result of this type of cooperation between HEls. ${ }^{242}$

Some HEls deliver programmes through distance education media, relying primarily on web-based approaches to programme delivery. However, HEls reported that online delivery presents a number of challenges, including due to rapid change in the sector (Clarke et al., 2018). The current strategy states that the further development of online programmes by Irish HEls represents an important strand of future transnational higher education provision (Department of Education and Skills, 2016a).

239 RCSI, 'RCSI and UCD Malaysia Campus officially launched by Minister for Education and Skills, Richard Bruton TD', available at http://www.rcsi.ie/index.jsp? $=100 \& n=110 \& a=11619$.

240 Consultation with HECA, December 2018. See also Dublin Business School, 'DBS launch partnership with leading Malaysian College', https://www.dbs.ie/about-dbs/news-and-events/2015/06/30/dbs-launches-partnership-withleading-malaysian-college.

241 AIT, 'AIT delighted to partner with Jianghan University for Visual Design Course', available at https://www.ait.ie/newsand-events/news/ait-delighted-to-partner-with-jianghan-university-for-visual-design-course.

242 Enterprise Ireland, 'Minister Halligan leads Enterprise Ireland Education Mission to China', press release, 19 October 2018, available at https://www.enterprise-ireland.com/en/news/pressreleases/2018-press-releases/minister-halliganleads-enterprise-ireland-education-mission-to-china.html. 


\section{CONCLUSIONS}

Increasing the number of international students forms an integral part of internationalisation strategies in the EU and Ireland (EMN, forthcoming). Such students are commonly seen as being an important element in Europe's response to demographic changes and demand for highly-skilled labour shortages more generally (IOM, 2008). Immigration of non-EEA nationals for the purposes of higher-level study in Ireland grew by 45 per cent between 2013, when 9,325 first residence permits were issued to students, and 2017, when 13,519 such permits were issued.

This study examined policy, law and practice relating to international students undertaking a programme of higher education in Ireland. In particular, it looked at measures to attract non-EEA students to Ireland and to retain such students following the completion of their studies. The study focused on recent developments in policy on the internationalisation of higher education and changes to the student immigration framework that took place between 2012 and 2018.

\section{DATA ON NON-EEA STUDENTS IN IRELAND}

Two main sources of data exist on non-EEA students in Ireland: data on residence permits issued for study collected by the Garda National Immigration Bureau (GNIB) and the Irish Naturalisation and Immigration Service (INIS) and reported by Eurostat; and data on enrolments in publicly funded higher education institutions (HEIs) collected and reported by the HEA. Data on students in private HEls are not collected at national level. The upward trends in both residence permits issued for study and enrolments in public HEls reflect in part an increased policy focus on attracting non-EEA students to Ireland.

The share of students in full-time higher education programmes who are of nonEEA origin grew from six per cent in 2013 to eight per cent in the 2017-2018 academic year. ${ }^{243}$ China is the top country of origin for non-EEA students, while Malaysia, the US, Canada, India and Saudi Arabia have also featured in the top five countries between 2013 and 2016. ${ }^{244}$ The most popular field of study among nonEEA students in the 2017-2018 academic year was health and welfare, followed by business, administration and law, and engineering, manufacturing and

243 Consultation with HEA, December 2018.

244 Eurostat, 'Mobile students from abroad enrolled by education level, sex and country of origin', [educ_uoe_mobs02], available at http://appsso.eurostat.ec.europa.eu/nui/show.do?dataset=educ_uoe_mobs02\&lang=en. 
construction. Non-EEA students were primarily concentrated in honours bachelor's degree and master's degree programmes. ${ }^{245}$

\section{INTERNATIONAL EDUCATION AND IMMIGRATION POLICY DEVELOPMENTS}

The fact that two international education strategies have been published since 2010 reflects the importance attached to promoting higher education in Ireland. The overall vision of the current strategy is 'to support Ireland to become internationally recognised for the development of global citizens through our internationalised education system and a market leader in attracting international student talent'.

A report commissioned by the Higher Education Authority (HEA) in 2018 found that, while significant internationalisation efforts have been made by HEls, these institutions were constrained in their efforts by a lack of resources in the face of funding cuts to the higher education sector (Clarke et al., 2018). Funding and capacity constraints mean that a potential increase in international students following Brexit has been identified as a risk for the higher education sector (Royal Irish Academy Brexit Taskforce, 2017).

The introduction of the current strategy coincided with several reforms to regulations governing non-EEA student immigration, which aimed to enhance Ireland's reputation as a destination for non-EEA students. This includes the ongoing overhaul of the regulatory framework for international education providers and introduction of the International Education Mark (IEM), which will be a requirement for education providers hosting international students. The Qualifications and Quality Assurance (Education and Training) (Amendment) Bill 2018, which provides for the IEM's introduction, was initiated in the Oireachtas on 1 August 2018 and, as of May 2019, is before the Seanad.

\section{PROMOTION OF IRELAND AS A DESTINATION FOR NON-EEA STUDENTS}

A number of initiatives are in place at national and institutional level to target international students, with the aim of encouraging them to study in Ireland. Promotional activities include international education fairs and media and digital campaigns. A number of government and $\mathrm{HEI}$ scholarships are available to non-EEA students, ${ }^{246}$ some of which were established to attract students and support Ireland's international development policy. HEls, Enterprise Ireland and the Department of Foreign Affairs and Trade have also worked to develop and mobilise

245 Consultation with HEA, December 2018.

246 For further information on scholarships provided by various other HEls in Ireland, see: Education in Ireland, 'Scholarships', available at https://www.educationinireland.com/en/How-Do-I-Apply-/Tuition-CostsScholarships/Scholarships. 
alumni abroad. However, HEls reported that Ireland is not well known in key markets due to a lack of a coordinated strategic effort at national level and insufficient government funding for promotional activities (Clarke et al., 2018).

\section{FACILITATING ADMISSION AND STAY OF NON-EEA STUDENTS}

The EU Directives relating to non-EEA students have sought to harmonise admission conditions across EU Member States to facilitate student mobility. While Ireland has not opted into the Directives relating to non-EEA students, conditions in place for non-EEA nationals applying for a study visa and/or residence permission in Ireland are similar to those that have been applied at EU level.

A number of challenges relating to admission conditions were reported. Following the High Court judgment in Chubb European Group PLC $v$ The Health Insurance Authority, stakeholders expressed concerns that costs for private health insurance may increase for non-EEA students and may impact on student recruitment. ${ }^{247}$ Stakeholders also observed that students have faced difficulties in scheduling appointments to register or renew their residence permission at INIS. ${ }^{248}$ INIS is considering a range of options to improve the registration and renewal processes in advance of the 2019 student peak period of September to December. ${ }^{249}$ The abolition of the re-entry visa system from 13 May 2019 was welcomed. ${ }^{250}$

Enterprise Ireland and the HEA emphasised the quality of the student experience as a factor in attracting and retaining non-EEA students. ${ }^{251} \mathrm{HEls}$ offer a range of supports to international students (Clarke et al., 2018). Both HEls and students themselves have identified difficulty in securing accommodation as one of the greatest challenges facing international students in Ireland (McGuire, 2016; Fitzgerald, 2017; Clarke et al., 2018). Providing good quality information on Irish immigration law and policy to prospective students is another important issue here. However, a survey of international students in Ireland in 2015 found that most non-EEA students had only some, little or no knowledge of immigration policies or procedures (Farrelly and Murphy, 2017).

\section{LABOUR MARKET ACCESS DURING AND AFTER STUDIES}

Permission to work during and after studies is another facet of Ireland's attraction and retention package. While recent reforms sought to tighten the student

247 ICOS, 'ICOS Statement on High Court Judgement in the case of the Health Insurance Authority (HIA) v Chubb European Group plc on 22 October, 2018', available at https://www.internationalstudents.ie/news/icos-statement-high-courtjudgement-case-health-insurance-authority-hia-v-chubb-european-group; Consultation with HEI, November 2018; Consultation with IUA, December 2018; Consultation with THEA, December 2018.

248 Interview with ICOS, October 2018; Interview with Crosscare, October 2018.

249 Consultation with INIS, December 2018.

250 Consultation with HECA, April 2019.

251 Interview with Enterprise Ireland, November 2018; Interview with HEA, November 2018. 
immigration regime, Arnold at al. (2017) noted that work outside of the permitted hours of 20 hours per week during the academic term and up to 40 hours per week during holiday periods is still a common feature of student immigration in Ireland. Migrant Rights Centre Ireland ( $\mathrm{MRCl}$ ) observed that, due to the work concession, many students are employed in part-time work, which is more present in sectors in which they are particularly vulnerable to exploitation (MRCI, 2015; Gilmartin et al., 2016).

The Third Level Graduate Programme (TLGP) allows non-EEA students at Level 8 of the National Framework of Qualifications (NFQ) and above to remain in Ireland for a certain period of time following graduation for the purposes of seeking employment. In order to reside in Ireland beyond the timeframe of the TLGP, international graduates must have secured employment on the basis of a general employment permit, critical skills employment permit or research hosting agreement. Concerns have been expressed in media reports about the lack of awareness among some employers regarding non-EEA students' entitlement to work under the TLGP (Pollak, 2019). Permission to stay under it was granted to 2,089 non-EEA students in 2017, up from 653 in 2012. The number of international graduates who have secured an employment permit following graduation also grew from 48 in 2013 to 871 in 2017.

\section{COOPERATION WITH NON-EEA COUNTRIES ON HIGHER EDUCATION}

A significant number of agreements are in place between the Irish State and third countries relating to higher education (Finn and O'Connell, 2012; Clarke et al., 2018). Bilateral and multilateral agreements signed by the State and HEls with governments and HEls in non-EEA countries facilitate student mobility. Irish HEls have also developed global relationships by establishing campuses overseas and offering programmes in partnership with institutions and providers abroad. Enterprise Ireland observed that institutional engagements worldwide continue to increase in line with the objectives of the current strategy. ${ }^{252}$

252 Interview with Enterprise Ireland, November 2018. 


\section{REFERENCES}

Arnold, S., S. Whelan and E. Quinn (2017). Illegal employment of non-EU nationals in Ireland, European Migration Network, ESRI Research Series No. 64, Dublin: Economic and Social Research Institute.

Barrett, A., F. McGinnity and E. Quinn (eds.) (2017). Monitoring report on integration 2016, Dublin: Economic and Social Research Institute.

Bennetot Pruvot, E., T. Estermann and V. Kupriyanova (2017). Public Funding Observatory: Report 2017, European Universities Association, available at

https://www.eua.eu/downloads/publications/eua-pfo-report-december2017.pdf.

Bennetot Pruvot, E., T. Estermann and V. Lisi (2019). Public Funding Observatory: Report 2018, European Universities Association, available at https://eua.eu/downloads/publications/eua\%20pfo\%202018\%20report_14\%20m arch\%202019_final.pdf.

Bindenagel, C.J. (2018). 'International students and the GNIB', The Irish Times, 2 October 2018, available at

https://www.irishtimes.com/opinion/letters/international-students-and-thegnib-1.3648008.

Civinini, C. (2018). 'Ireland's new re-entry visa application system worries students', The PIE News, 21 September 2018, available at

https://thepienews.com/news/irelands-new-re-entry-visa-application-systemworries-students/.

Clarke, M., L.H. Yang and D. Harmon (2018). The internationalisation of Irish higher education, Dublin: The Higher Education Authority.

Commission of the European Communities (1994). Communication from the Commission to the Council and the European Parliament on immigration and asylum policies, $\operatorname{COM}(94) 23$ final, available at

https://eur-lex.europa.eu/legal-content/EN/TXT/PDF/?uri=CELEX:51994 DC0023\& qid $=1556488562432 \&$ from $=E N$.

Council of the European Union (1991). Presidency conclusions, SN 271/1/91, available at https://www.consilium.europa.eu/media/20519/1991_december__maastricht_eng_.pdf.

Council of the European Union (1994). Council Resolution of 30 November 1994 on the admission of third-country nationals to the territory of the Member States for study purposes, No. C 274/10, available at https://eur-lex.europa.eu/legalcontent/EN/TXT/PDF/?uri=CELEX:31996Y0919(04)\&from=EN.

Council of the European Union (2010). The Stockholm Programme - An open and secure Europe serving and protecting the citizens, 2010/C 115/01, available at https://eurlex.europa.eu/LexUriServ/LexUriServ.do?uri=OJ:C:2010:115:0001:0038:EN:PDF. 
Courtois, A. (2017). 'The significance of international student mobility in students' strategies at third level in Ireland', NUI Discussion Paper, No. 1, available at http://www.nui.ie/publications/docs/2017/NUI_Research_Report_Discussion_Pa per_01.pdf.

Department of Business, Enterprise and Innovation (2015a). Action plan for jobs 2015, available at

https://dbei.gov.ie/en/Publications/Publication-files/Action-Plan-for-Jobs2015.pdf.

Department of Business, Enterprise and Innovation (2015b). Action plan for Jobs 2015, first progress report, available at

https://dbei.gov.ie/en/Publications/Publication-files/Action-Plan-for-Jobs-First-

Progress-Report.pdf.

Department of Business, Enterprise and Innovation and Department of Foreign Affairs and Trade (2017). Ireland connected: Trading and investing in a dynamic world, available at

https://merrionstreet.ie/MerrionStreet/en/ImageLibrary/20170308_Ireland_Con nected.pdf.

Department of Business, Enterprise and Innovation (2018). Review of economic migration Policy - Report of the Interdepartmental Group, available at https://dbei.gov.ie/en/Publications/Publication-files/Review-of-EconomicMigration-Policy.pdf.

Department of Education and Science (2004). Internationalisation of Irish education services: Report of the Interdepartmental Working Group, available at https://www.education.ie/en/Publications/Policy-Reports/Internationalisationof-Irish-Education-Services-Report-of-Interdepartmental-Working-Group.pdf.

Department of Education and Skills (2010). Investing in global relationships: Ireland's international education strategy 2010-15, Dublin: Department of Education and Skills.

Department of Education and Skills (2011). National strategy for higher education to 2030, available at https://www.education.ie/en/Publications/Policy-Reports/National-Strategy-forHigher-Education-2030. pdf.

Department of Education and Skills (2016a). Irish educated, globally connected: An international education strategy for Ireland, 2016-2020, Dublin: Department of Education and Skills.

Department of Education and Skills (2016b). Ireland's national skills strategy 2025, available at

https://www.education.ie/en/Publications/Policy-Reports/pub_national _skills_strategy_2025.pdf.

Department of Education and Skills (2017). Languages connect: Ireland's strategy for foreign languages in education, available at https://www.education.ie/en/Schools-Colleges/Information/Curriculum-andSyllabus/Foreign-Languages-Strategy/fls_languages_connect_strategy.pdf. 
Department of Education and Skills (2019). Cumasú. Empowering through learning: Action plan for education 2019, available at

https://www.education.ie/en/Publications/Corporate-Reports/Strategy-

Statement/action-plan-for-education-2019.pdf.

Department of Education and Skills and Department of Justice and Equality (2014). Regulatory reform of the international education sector and the student immigration regime, policy statement, available at

https://www.education.ie/en/Publications/Policy-Reports/Regulatory-Reform-ofthe-International-Education-Sector-and-the-Student-Immigration-Regime.pdf.

Department of Education and Skills and Department of Justice and Equality (2015). Reform of the international education sector and student immigration system: Government policy statement May 2015, available at

http://www.inis.gov.ie/en/INIS/Policy\%20statement\%20on\%20International\%20

Education\%20Final.pdf.

Department of Foreign Affairs and Trade (2013). One world, one future: Ireland's policy for international development, available at

https://www.irishaid.ie/media/irishaid/\%20allwebsitemedia/20newsandpublicati ons/publicationpdfsenglish/one-world-one-future-irelands-new-policy.pdf.

Department of Foreign Affairs and Trade (2018). Transforming our world: Help Ireland make a difference. Ireland's new international development policy: Public consultation paper, available at

https://www.irishaid.ie/media/irishaid/publications/Irish-Aid-White-paper-

Consultation-Process.pdf.

Department of Foreign Affairs and Trade (2019). A better world: Ireland's policy for international development, available at

https://www.irishaid.ie/media/irishaid/aboutus/\%20abetterworldirelandspolicyf orinternationaldevelopment/A-Better-World-Irelands-Policy-for-International-

Development.pdf.

EURAXESS Ireland (2013). Attracting researchers to Ireland: The impact of the scientific visa, Dublin: EURAXESS Ireland.

European Commission (2002). Proposal for a Council Directive on the conditions of entry and residence of third-country nationals for the purposes of studies, vocational training or voluntary service, $\operatorname{COM(2002)} 548$ final, available at

https://eur-lex.europa.eu/legal-

content/EN/TXT/?qid=1556488443283\&uri=CELEX:52002PC0548.

European Commission (2011). Report from the Commission to the European Parliament and the Council on the application of Directive 2004/114/EC on the conditions of admission of third-country nationals for the purposes of studies, pupil exchange, unremunerated training or voluntary service, $\operatorname{COM}(2011) 587$ final, available at https://eur-lex.europa.eu/legal-

content/EN/TXT/PDF/?uri=CELEX:52011DC0587\&from=EN. 
European Commission (2013). Proposal for a Directive of the European Parliament and of the Council on the conditions of entry and residence of third-country nationals for the purpose of research, studies, pupil exchange, remunerated and unremunerated training, voluntary service and au pairing, $\operatorname{COM}(2013) 151$ final, available at https://eur-lex.europa.eu/legal-content/EN/TXT/?uri=CELEX\%3A52013PC0151.

European Commission (2015). A European agenda on migration, COM(2015) 240 final, available at

https://eur-lex.europa.eu/legalcontent/EN/TXT/PDF/?uri=CELEX:52015DC0240\&qid=1556488737189\&from=EN .

European Migration Network (2013). Immigration of international students to the EU: European Migration Network study 2012, Brussels: European Migration Network.

European Migration Network (forthcoming). Attracting and retaining international students in the EU, Brussels: European Migration Network.

European Union (2018). The EU in support of the Bologna process, available at https://publications.europa.eu/en/publication-detail/-/publication/e437d57d5e32-11e8-ab9c-01aa75ed71a1.

Expert Group on Future Funding of International Education (2016). Investing in national ambition: A strategy for funding higher education, available at https://www.education. ie/en/Publications/Policy-Reports/Investing-in-NationalAmbition-A-Strategy-for-Funding-Higher-Education.pdf.

Farrelly, T. and T. Murphy (2017). Transitions of international students into higher education in Ireland, Briefing Paper 1, Dublin: National Forum for the Enhancement of Teaching and Learning in Higher Education.

Finn, M. and P.J. O'Connell (2012). Immigration of International Students to the EU: Ireland, European Migration Network, Dublin: Economic and Social Research Institute.

Finn, M. and M. Darmody (2017). 'What predicts international higher education students' satisfaction with their study in Ireland?', Journal of Further and Higher Education, Vol. 41, No. 4, pp. 545-555.

Fitzgerald, C. (2017). 'Fraud, high rents, no accommodation: The problems facing Ireland's international students', TheJournal.ie, 28 May 2017, available at http://www.thejournal.ie/international-students-problems-3409555-May2017/.

Gilmartin, M., P. Rojas Coppari and D. Phelan (2016). 'International student migration to Ireland', NIRSA Working Paper Series No. 80, available at

https://www.

maynoothuniversity.ie/sites/default/files/assets/document/NIRSAMGilmartinNO 80_0.pdf.

Government of Ireland (2017). National student accommodation strategy, available at https://www.education.ie/en/Publications/Policy-Reports/National-StudentAccommodation-Policy.pdf.

Government of Ireland (2019). Future jobs Ireland 2019: Preparing now for tomorrow's economy, available at https://dbei.gov.ie/en/Publications/Publication-files/Future-Jobs-Ireland2019.pdf. 
Griffin, R. (2018a). 'Opinion: While Brexit presents opportunities for the sector, Irish universities lack the investment to be in a state of readiness to benefit from Brexit', RTE Brainstorm, 18 October 2018, available at https://www.rte.ie/brainstorm/2018/1017/1004788-how-will-brexit-impact-onirish-universities/.

Griffin, R. (2018b). 'How will Brexit impact on Irish universities?', available at https://www.rte.ie/eile/brainstorm/2018/1017/1004788-how-will-brexit-impacton-irish-universities/.

Grossen, A. (2018). 'Immigration appointments remain a struggle for international students', University Observer, 24 September 2018, available at https://universityobserver.ie/immigration-appointments-remains-a-struggle-forinternational-students/.

Gusciute, E., E. Quinn and A. Barrett (2015). Business migration to Ireland, European Migration Network, ESRI Research Series No. 43, Dublin: Economic and Social Research Institute.

Higher Education Authority (HEA) (2013). Higher education system performance framework 2014-2016, available at

http://hea.ie/assets/uploads/2017/06/DES-System-Performance-Framework.pdf.

Higher Education Authority (HEA) (2015). Report on student accommodation: Demand and supply, available at https://www.education.ie/en/Publications/Education-Reports/Report-onStudent-Accommodation-Demand-and-Supply.pdf.

Higher Education Authority (HEA) (2017a). Higher education system performance 20142017, available at http://hea.ie/assets/uploads/2018/01/Higher-Education-System-Performance2014-17-report.pdf.

Higher Education Authority (HEA) (2017b). Review of the allocation model for funding higher education institutions: Final report by the Independent Expert Panel for the $H E A$, available at http://hea.ie/assets/uploads/2018/01/HEA-RFAM-Final-Report-forPublication.pdf.

Higher Education Authority (HEA) (2017c). Higher education factsheet: Internationalisation, HEA, available at http://hea.ie/assets/uploads/2017/12/INT-Factsheet-Final-PDF-version.pdf.

Higher Education Authority (HEA) and Department for the Economy (2018). An analysis of existing statistics on student flows between the Republic of Ireland and Northern Ireland in higher education, available at https://hea.ie/assets/uploads/2018/12/ROI-NI-Student-Flows-Report-December2018-FINAL.pdf.

Immigrant Council of Ireland (2009). 'Submission to Government: New immigration regime for full time non-EEA students', available at https://www.immigrantcouncil.ie/sites/default/files/201711/IMM\%202009\%20Submission\%20to\%20DJE\%20on\%20International\%20Stude nt\%20Guidelines.pdf. 
International Organization for Migration (IOM) (2008). World migration 2008: Managing labour mobility in the evolving global economy, IOM World Migration Report Series, Vol. 4, Geneva: IOM.

International Organization for Migration (IOM) (2018). World migration report 2018, Geneva: IOM, available at

https://www.iom.int/sites/default/files/country/docs/china/r5_world_migration _report_2018_en.pdf.

Irish Council for International Students (ICOS) (2018). 'Public consultation on Ireland's new international development policy: Response of the Irish Council for International Students (ICOS)', available at

https://dochas.ie/sites/default/files/ICOS\%20submission\%20to\%20Public\%20Con sultation\%20on\%20new\%20international\%20development\%20policy\%20v3.pdf.

Irish Higher Education Quality Network (IHEQN) (2009). Provision of education to international students: Code of practice and guidelines for Irish higher education institutions, available at http://www.iheqn.ie/_fileupload/File/IHEQN_62439738.pdf.

Irish Naturalisation and Immigration Service (INIS) (2009). Proposed new immigration regime for full time non-EEA students, available at http://www.inis.gov.ie/en/INIS/Student\%20Immigration\%20Review\%20\%201\%20September\%2009\%20(Final).pdf.

Irish Naturalisation and Immigration Service (INIS) (2010). New immigration regime for full time non-EEA students: Final report and recommendations of the Interdepartmental Committee, available at

http://www.inis.gov.ie/en/INIS/Students\%20BookletA4\%20(white\%20cover)\%20s ept\%202010.pdf.

Irish Naturalisation and Immigration Service (INIS) (2011a). New immigration regime for full time non-EEA students: Guidelines for degree programme students, available at http://www.inis.gov.ie/en/INIS/Guidelines\%20for\%20Degree\%20Programme\%20 Students\%20-\%20July\%202011.pdf.

Irish Naturalisation and Immigration Service (INIS) (2011b). New immigration regime for full time non-EEA students: Guidelines for language and non-degree programme students, available at http://www.inis.gov.ie/en/INIS/Guidelines\%20for\%20Language\%20and\%20NonDegree\%20Programme\%20Students.pdf.

Irish Naturalisation and Immigration Service (INIS) (2011c). New immigration regime for full time non-EEA students: Guidelines for colleges offering courses to full time non-EEA students, INIS, available at http://www.inis.gov.ie/en/INIS/Guidelines\%20for\%20Colleges\%20\%20August\%202011.pdf.

Irish Naturalisation and Immigration Service (INIS) (2016a). Policy document on non-EEA family reunification, available at http://www.inis.gov.ie/en/INIS/Family\%20Reunification\%20Policy\%20Document. pdf. 
Irish Naturalisation and Immigration Service (INIS) (2016b). Start-up Entrepreneur Programme: Guidelines, available at

http://www.inis.gov.ie/en/INIS/step-applic-guide-dec2016.pdf.

Irish Naturalisation and Immigration Service (INIS) (2017). Third Level Graduate Programme: Immigration rules for non-EEA students, available at http://www.inis.gov.ie/en/INIS/Third\%20Level\%20Graduate\%20Programme.pdf.

Irish Naturalisation and Immigration Service (INIS) (2018a). Interim list of eligible programmes for student immigration permission: Arrangements applying to higher education and professional programmes from 2 June 2015 (updated 14 September 2018), available at http://www.inis.gov.ie/en/INIS/ilep-hep-criteria.pdf.

Irish Naturalisation and Immigration Service (INIS) (2018b). Service improvement plan 2018-2020, available at http://www.inis.gov.ie/en/INIS/inis-service-improvement-plan-2018-to-2020.pdf.

Irish Times (2014). 'Keeping faith with foreign students who come to Ireland to learn English', 17 May 2014, available at https://www.irishtimes.com/news/education/keeping-faith-with-foreignstudents-who-come-to-ireland-to-learn-english-1.1798919).

Irish Universities Association (2018). Irish Universities Association (2018). Ireland's future talent: A charter for Irish universities, available at https://www.iua.ie/publication/irelands-future-talent-a-charter-for-irishuniversities/.

Joyce, C. and E. Gusciute (2015). Annual policy report on migration and asylum 2013: Ireland, European Migration Network, Dublin: Economic and Social Research Institute.

Joyce, C. and S. Whelan (2015). Annual policy report on migration and asylum 2014: Ireland, European Migration Network, Dublin: Economic and Social Research Institute.

Kelly, P. (2018a). 'International students may face insurance hikes following High Court case', Trinity News, 27 June, available at http://trinitynews.ie/news/2018/06/international-students-may-face-insurancehikes-following-high-court-case/.

Kelly, L. (2018b). 'Irish colleges falling behind global education peers in digital drive for student recruitment', The Irish Independent, 14 November 2018, available at https://www.independent.ie/business/irish/irish-colleges-falling-behind-globaleducation-peers-in-digital-drive-for-student-recruitment-37524297.html.

Knight, J. (2015). 'Updated definition of internationalization', International Higher Education, No. 33.

Kuzmane, D., S. Jahnke, A. Perez Encinas, E. Alfranseder and J. Fellinger (2017). HousErasmus+ research report, European University Foundation and Erasmus Student Network AISBL. 
McGuire, P. (2016). 'Overseas students: An international solution to an Irish problem?', The Irish Times, 17 May 2016, available at https://www.irishtimes.com/news/education/overseas-students-aninternational-solution-to-an-irish-problem-1.2644213.

MRCI (2015). Workers on the move: Past lessons and future perspectives on Ireland's labour migration, Dublin: $\mathrm{MRCl}$.

Migrant Rights Centre Ireland (2018). 'MRCl submission to consultation on proposed guiding principles to frame the State's economic migration policy', available at https://www.mrci.ie/wp-content/uploads/2018/04/MRCl-Submission-onProposed-Guiding-Principles-on-State\%E2\%80\%99s-Economic-Migration-Policy2018.pdf.

Murray, N. (2018). 'Funding decision for third level delayed', The Irish Examiner, 7 July 2018, available at https://www.irishexaminer.com/ireland/funding-decision-for-third-level-delayed472666.html.

O'Brien, C. (2018a). 'Students face being priced out of 'luxury' accommodation', The Irish Times, 12 July 2018, available at https://www.irishtimes.com/news/education/students-face-being-priced-out-ofluxury-accommodation-1.3561845.

O'Brien, C. (2018b). 'Trinity likely to be hardest hit by disruption to flow of students after Brexit', The Irish Times, 13 December 2018, available at https://www.irishtimes.com/news/education/trinity-likely-to-be-hardest-hit-bydisruption-to-flow-of-students-after-brexit-1.3730675.

O’Brien, C. (2019). 'Government hopes hard Brexit would not affect fees for cross-Border students', The Irish Times, 3 January 2019, available at https://www.irishtimes.com/news/education/government-hopes-hard-brexitwould-not-affect-fees-for-cross-border-students-1.3747155.

OECD (2008). The global competition for talent: Mobility of the highly skilled, Paris: OECD Publishing.

OECD (2018). Education at a glance 2018: OECD indicators, Paris: OECD Publishing.

OECD and European Commission (2017). Supporting entrepreneurship and innovation in higher education in Ireland, OECD Skills Studies, Paris: OECD Publishing.

Oireachtas Library \& Research Service (2017). The opportunity of Brexit for Irish higher education, available at https://data.oireachtas.ie/ie/oireachtas/libraryResearch/2017/2017-10-05_theopportunities-of-brexit-for-irish-higher-education_en.pdf.

Oireachtas Library \& Research Service (2018). Bill digest: Qualifications and Quality Assurance (Education and Training) (Amendment) Bill 2018, available at https://data.oireachtas.ie/ie/oireachtas/libraryResearch/2018/2018-10-12_billdigest-qualifications-and-quality-assurance-education-and-training-amendmentbill-2018_en.pdf. 
Pollak, S. (2015). 'Garda measures aim to tackle long visa queues', The Irish Times, 28 September 2015, available at https://www.irishtimes.com/news/social-affairs/garda-measures-aim-to-tacklelong-visa-queues-1.2369711.

Pollak, S. (2018a). "Bots' used to block immigrants from making visa appointments', The Irish Times, 7 September 2018, available at https://www.irishtimes.com/news/social-affairs/bots-used-to-block-immigrantsin-ireland-from-making-visa-appointments-1.3620957.

Pollak, S. (2018b). 'Immigrants have to pay sites to secure visa appointments', The Irish Times, 16 October 2018, available at https://www.irishtimes.com/news/social-affairs/immigrants-have-to-pay-sitesto-secure-visa-appointments-1.3664568.

Pollak, S. (2018c). 'Online visa registration system to be replaced in 2019, says department', The Irish Times, 6 December 2018, available at https://www.irishtimes.com/news/social-affairs/online-visa-registration-systemto-be-replaced-in-2019-says-department-1.3721123.

Pollak, S. (2019). '“We have a skilled workforce under our noses that we're not using"', The Irish Times, 30 April 2019, available at https://www.irishtimes.com/news/social-affairs/we-have-a-skilled-workforceunder-our-noses-that-we-re-not-using-1.3875335.

Pritchard, R. and M. Slowey (2017). 'Resilience: A high price for survival? The impact of austerity on Irish higher education, South and North', in Heffernan, E., J. McHale and N. Moore-Cherry (eds) Debating austerity in Ireland: crisis, experience and recovery, Dublin: Royal Irish Academy.

Quality and Qualifications Ireland (QQI) (2013). Green Paper on the International Education Mark, available at

https://www.qqi.ie/Publications/Publications/Green\%20Paper\%20on\%20the\%20। nternational\%20Education\%20Mark\%20-\%20For\%20Consultation.pdf.

Quality and Qualifications Ireland (QQI) (2014). White paper: Policy on authorisation to use the International Education Mark, available at https://www.qqi.ie/Publications/Publications/White\%20Paper\%20-

\%20Policy\%20on\%20Authorisation\%20to\%20use\%20the\%20International\%20Edu cation\%20Mark.pdf.

Quality and Qualifications Ireland (QQI) (2015). Code of practice for provision of programmes of education and training to international learners, available at https://www.qqi.ie/Downloads/Code\%20of\%20Practice.pdf.

Quinn, E. and E. Gusciute (2013). Attracting highly qualified and qualified third-country nationals: Ireland, European Migration Network, Dublin: Economic and Social Research Institute.

Royal Irish Academy Brexit Taskforce (2017). Research and higher education on the island of Ireland after Brexit: A report by the Royal Irish Academy Brexit Taskforce, Dublin: Royal Irish Academy. 
Sheridan, A. (2017). Annual report on migration and asylum 2016: Ireland, European Migration Network, Dublin: Economic and Social Research Institute.

Sheridan, A. (2018). Annual report on migration and asylum 2017: Ireland, European Migration Network, Dublin: Economic and Social Research Institute.

Sheridan, A. and S. Whelan (2016). Annual policy report on migration and asylum 2015: Ireland, European Migration Network, Dublin: Economic and Social Research Institute.

Smith, A. (2015). Part of the family? The experiences of au pairs in Ireland, Dublin: MRCI, available at

http://www.mrci.ie/wp-content/uploads/2012/10/PartofTheFamily.pdf.

Southern Cross Consulting (2018). Understanding U.S. study abroad in Ireland: Economic impact and future possibilities. Main research report 2018, available at https://www.educationinireland.com/en/Publications/Understanding\%20US\%20 Study\%20Abroad\%20in\%20Ireland.pdf.

Synnott, J. (2018). 'Change in visa process sparks student frustrations', The University Times, 13 September 2018, available at http://www.universitytimes.ie/2018/09/change-in-visa-process-sparks-studentfrustrations/.

Task Force on Students Affected by Private College Closures (2014). Report of the Task Force on Students Affected by Private College Closures, Dublin: Department of Education and Skills and Department of Justice and Equality.

TERMINALFOUR (2018). Higher education: Digital marketing and web survey 2018, available at https://www.terminalfour.com/. 
EMN Ireland,

Economic and Social

Research Institute,

Whitaker Square,

Sir John Rogerson's Quay,

Dublin 2, Ireland

Telephone +35318632000

Email emn.ireland@esri.ie

Web www.emn.ie / www.esri.ie

Twitter @EMNIreland

ISBN: 978-0-7070-0493-8 